\title{
The Mobile-Source Provisions of the Clean Air Act
}

\author{
David P. Currie $\dagger$
}

\section{Table of Contents}

I. The Statutory Framework $\ldots \ldots \ldots \ldots \ldots \ldots \ldots 813$

II. Historical Development of Restrictions on Automotive Pollution $\ldots \ldots \ldots \ldots \ldots \ldots \ldots \ldots \ldots \ldots . . \ldots 14$

A. California and the 1965 Federal Statute ..... 815

B. Technology Forcing $\ldots \ldots \ldots \ldots \ldots \ldots \ldots, 816$

C. Postponements ...................... 818

III. Light-Duty Vehicles $\ldots \ldots \ldots \ldots \ldots \ldots \ldots \ldots \ldots .819$

A. The Basic Emission Standards .......... 819

1. The Statutory Provisions ............. 819

2. The Explanation ................. 819

B. Additional Light-Duty Standards Under Section 202(a) ......................... 821

1. Other Pollutants ................. 821

2. Nonexhaust Emissions ............... 823

3. Tightening the Statutory Standards ......8.823

4. The Relevance of Technology and Cost .... 824

C. The Definition of Light-Duty Vehicles ....... 824

D. High-Altitude Provisions ............ 825

E. Waiver Provisions $\ldots \ldots \ldots \ldots \ldots \ldots \ldots \ldots . \ldots 28$

1. Nitrogen Oxides ..................... 828

2. Carbon Monoxide .................. 830

a. Unavailable Technology ........... 831

i. Forecasting, Model Diversity, and $\mathrm{Ca}$ talyst Replacement ........... 831

ii. Cost .................. 832

b. NAS Study ................. 833

c. Public Interest .................. 834

d. Good Faith ........................ 834

e. Public Health .................. 835

f. Effect of Denial ............... 836

3. Hearings ................... 837

a. The International Harvester Decision ... 837

b. Oral Participation ............... 838

† Harry N. Wyatt Professor of Law, The University of Chicago; Member, Illinois Air Pollution Control Board, 1969-1970; Illinois Coordinator of Environmental Quality, 1970; Chairman, Illinois Pollution Control Board, 1970-1972. 
c. Decision on the Record ............ 840

i. The Context .............. 841

ii. The Statute ................... 843

iii. Due Process ............... 844

d. Cross-examination and Comment ..... 845

e. $N O_{x}$ Waivers ................. 847

IV. Other Vehicles .................... 848

A. Ultimate and Interim Heavy-Duty Standards .. 849

B. Revisions ..................... 851

C. Particulate Standards ............... 854

D. Light-Duty Trucks and Recreational Vehicles .. 857

E. Motorcycles ................... 859

V. Enforcement and Preemption $\ldots \ldots \ldots \ldots \ldots \ldots \ldots .659$

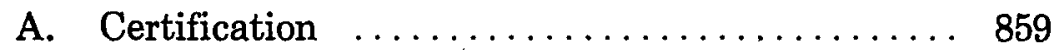

B. Production-Line Testing $\ldots \ldots \ldots \ldots \ldots \ldots \ldots 81$

C. Compliance in Use: Warranties .......... 864

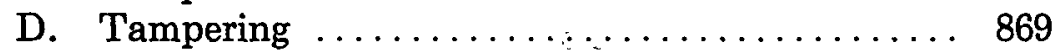

E. Remedies $\ldots \ldots \ldots \ldots \ldots \ldots \ldots \ldots \ldots \ldots$. 871

F. Nonconformance Penalties ............. 872

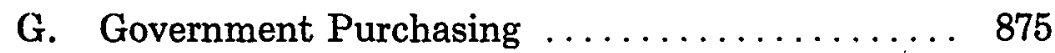

H. Preemption .................... 875

VI. Fugl Regulation $\ldots \ldots \ldots \ldots \ldots \ldots \ldots \ldots \ldots \ldots \ldots . \quad 876$

A. Registration ................... 877

B. . Testing $\ldots \ldots \ldots \ldots \ldots \ldots \ldots \ldots \ldots \ldots \ldots . \ldots . \ldots$

C. Controls and Prohibitions ............ 881

1. Standards to Protect Control Devices ..... 882

2. Standards to Protect Health and Welfare .. 885

D. Preemption ..................... 891

E. Manganese and the Ban on New Fuels and Addi-

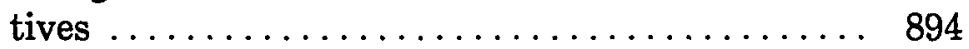

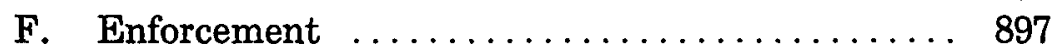

VII. AIrCRAft EMissions $\ldots \ldots \ldots \ldots \ldots \ldots \ldots \ldots \ldots . \ldots 98$

VIII. The Mobile-Source Provisions: AN Appraisal ..... 902

A. Technology Forcing .................. 902

1. Reasons for Optimism ............... 902

2. Reasons for Pessimism .............. 905

B. The Interstitial Nature of the Mobile-Source Provisions $\ldots \ldots \ldots \ldots \ldots \ldots \ldots \ldots \ldots \ldots \ldots$ 
Pollution has long been with us, and so have legal tools for pollution control. The past few years, however, have witnessed a veritable revolution in the law of pollution. Responding to a paroxysm of public pressure, legislative bodies at all levels of the American government have enacted volumes of unprecedentedly vigorous pollution-control measures whose importance and complexity warrant detailed examination.

The first federal air-pollution statute was two pages long; the present one, without case annotations, consumes 164 pages in a pamphlet of the United States Code Annotated. Its bewildering detail begins to rival that of the Internal Revenue Code. It has been the subject of a substantial body of judicial decision, and the regulations for its implementation occupied two volumes of the Code of Federal Regulations even before the 1977 statutory revisions.

The 1977 amendments have generated a renewed flurry of administrative activity. Significant new regulations appear almost weekly, and a second round of judicial interpretation is in the offing. My aim in this article is to furnish some assistance to lawyers, administrators, and courts in the initial process of applying the new law. In addition, I offer criticisms of the statute itself in the hope that some of the mistakes Congress has made may be avoided, not only in future efforts in the same field, but also in devising public policy with respect to other problems for which government intervention may be thought desirable.

\section{The Statutory Framework}

The basic elements of the present Clean Air Act ${ }^{1}$ are derived from the 1970 amendments, ${ }^{2}$ which were the subject of detailed revision in $1977 .{ }^{3}$ Provisions of earlier law for federal research, interstate compacts to fight pollution, and federal support of state control programs remain. ${ }^{4} \mathrm{~A}$ cumbersome conference procedure, which allowed the federal agency to convene local, state, and interstate enforcement bodies, was relegated to a minor role in $1970^{5}$ and abolished altogether in $1977 .^{\circ}$

142 U.S.C. $\$ \$ 7401-7642$ (Supp. I 1977) [hereinafter cited to the original sections of the Act and the current U.S.C.]. An enormous body of secondary literature is developing on the Clean Air Act. In addition to the various books and articles cited throughout this article, an entire issue of the Ecology Law Quarterly (volume 4, no. 3) was devoted to the Act in 1975.

2 Clean Air Act Amendments of 1970, Pub. L. No. 91-604, 84 Stat. 1676.

3 Clean Air Act Amendments of 1977, Pub. L. No. 95-95, 91 Stat. 685.

$1 \S \S 101-106,42$ U.S.C. $\S \S 7401-7406$ (Supp. I 1977).

5 Clean Air Act Amendments of 1970, Pub. L. No. 91-604, § 114(b), 84 Stat. 1688 (repealed 1977): "A conference may not be called . . . with respect to an air pollutant for which ... a national . . a ambient air quality standard is in effect . . . "

- Clean Air Act Amendments of 1977, Pub. L. No. 95-95, § 114, 91 Stat. 710. 
Direct federal regulatory authority was sharply increased in $1970^{7}$ and strengthened further in 1977. The Environmental Protection Agency may now adopt emission standards not only for new vehicles ${ }^{8}$ but for all aircraft, " for any source of a "hazardous" air pollutant (defined as one that "may cause an increase in mortality or an increase in serious irreversible, or incapacitating reversible, illness"), ${ }^{10}$ and for all new stationary sources of air pollution "which may contribute significantly to the endangerment of the public health or welfare," 11 as well as for existing stationary sources of a type regulated under this last provision.12 The EPA may regulate the contents of motor-vehicle fuels ${ }^{13}$ and adopt measures to protect the stratosphere. ${ }^{14}$ Moreover, an emergency provision authorizes the EPA, absent adequate state or local action, to sue to enjoin any emissions contributing to "an imminent and substantial endangerment to the health of persons." 15

Control of most existing stationary sources, however, remains an awkward cooperative federal-state enterprise. The EPA itself now promulgates the standards defining the acceptable quality of the air we breathe, and it does so for the whole country. ${ }^{16}$ But plans to implement these standards are to be adopted in the first instance by the states, subject to ultimate federal authority to ensure their consistency with detailed statutory requirements. ${ }^{17}$ Complex provisions were added in 1977 to prevent "significant deterioration" of areas cleaner than required by the air-quality standards, ${ }^{18}$ to protect visibility in scenic areas, ${ }^{19}$ and to regulate new and existing sources in areas not yet meeting the standards. ${ }^{20}$

\section{Historical Development of Restrictions on Automotive Pollution}

Transportation is the principal source of atmospheric concen-

'See Clean Air Act Amendments of 1970, Pub. L. No. 91-604, 84 Stat. 1676.

8 \& 202, 42 U.S.C. $\$ 7521$ (Supp. I 1977).

\& $\$ 231,42$ U.S.C. $\$ 7571$ (Supp. I 1977).

10 $\S 112,42$ U.S.C. $\S 7412$ (a)(1) (Supp. I 1977).

$" \S 111,42$ U.S.C. $\$ 7411$ (b)(1)(A) (Supp. I 1977).

$12 \S 111,42$ U.S.C. $\$ 7411$ (d) (Supp. I 1977).

$13 \S 211,42$ U.S.C. $\S 7545$ (Supp. I 1977).

$14 \S \S 150-159$, 42 U.S.C. $\S \S 7450-7459$ (Supp. I 1977).

$15 \S 303,42$ U.S.C. $\S 7603$ (Supp. I 1977).

is $\S 109,42$ U.S.C. $\$ 7609$ (Supp. I 1977).

$17 \S 110,42$ U.S.C. $\$ 7410$ (Supp. I 1977).

is $\S 127$ (a), 91 Stat. 731 (adding Clean Air Act $\$ \$ 160-169$ ) (current version at 42 U.S.C. $\S \S 7470-7479$ (Supp. I 1977)).

14 Id., $\S 128,91$ Stat. 742 (amending Clean Air Act $\S 169$ A) (current version at 42 U.S.C. $\S 7491$ (Supp. I 1977)).

${ }^{20}$ Clean Air Act Amendments of 1977, Pub. L. No. 95-95, $\S 129$ (b), 91 Stat. 745 (adding Clean Air Act $\S 171-178$ ) (current version at 42 U.S.C. $\$ \S 7501-7508$ (Supp. I 1977)). 
trations of hydrocarbons ( $\mathrm{HC})$, carbon monoxide (CO), and lead, and a principal source of nitrogen oxides $\left(\mathrm{NO}_{\mathrm{x}}\right) \cdot{ }^{21}$ Carbon monoxide, lead, and nitrogen oxides have been identified by the federal government as harmful to public health and welfare at concentrations frequently encountered in this country, ${ }^{22}$ and so have photochemical oxidants (principally ozone), which result from the action of sunlight on a mixture of hydrocarbons and nitrogen oxides. ${ }^{23}$ Motor vehicles have consequently been prime targets of regulatory efforts to reduce and to prevent air pollution. ${ }^{24}$

\section{A. California and the 1965 Federal Statute}

The injurious environmental impact of automotive emissions was first discovered in California, ${ }^{25}$ and it was California that first acted to regulate motor-vehicle pollution. ${ }^{26}$ In 1959 , the legislature authorized the Director of Public Health "to determine ... the maximum allowable standards of emissions of exhaust contaminants from motor vehicles which are compatible with the preservation of the public health including the prevention of irritation of the senses." ${ }_{27}$ The next year it required installation of control devices on new vehicles, and in some cases on used ones, upon certification that devices had been developed that were sufficient to meet the Public Health standards. ${ }^{28}$ Thus, although "public health" was the basis of the standards, they were not to be enforced until the technology became available. Progressively stricter standards have been adopted under these provisions and their successors, applicable first only to crankcase emissions, but later also to exhaust and to evaporative fuel losses. The more recent standards cover nitrogen oxides as well as carbon monoxide and hydrocarbons. ${ }^{29}$

21 See United States National Atr Pollution Control Administration, Air Qualtty Criteria for Carbon Monoxide 4-1, 4-2 (1970); United Statrs National Air Pollution Control Administration, Air Quality Criteria for Hydrocarbons 2-18 (1970); Environmental Protection Agency, Air Quality Critbria for Nitrogen Oxides 3-1 (1971); Ethyl Corp. v. EPA, 541 F.2d 1, 9 (D.C. Cir. 1976) (lead).

22 See authorities cited note 21 supra.

23 See United States National Air Pollution Control Administration, Air Qualtty Criteria for Photochemical Oxidants 2-3 to 2-10 \& passim (1970).

${ }^{21}$ See generally Anestis, Automotive Air Pollution and the Clean Air Amendments of 1970, in Environmental Protection 243 (L. Jaffe \& L. Tribe eds. 1971).

is See D. Carr, The Breath of Life $81-82$ (1965).

28 The history is briefly recounted in Kennedy \& Weekes, Control of Automobile Emissions-California Experience and the Federal Legislation, 33 LAW \& CONTEMP. Prob. 297 (1968).

271959 Cal. Stats. ch. $200, \S 1$ (repealed 1967).

2k 1961 Cal. Stats. ch. 23, § I (1960 Special Sess.) (current version at Cal. Health \& SAFETY CodE §§ 24386, 24390 (1967)).

2) See, e.g., Cal. Administrative Code, tit. 13, § 1955 (1977). 
Recognition that California was not alone in its difficulties, combined with the desirability of uniform standards for manufacturers and users of mobile equipment, ${ }^{30}$ induced Congress in 1965 to make emissions from new motor vehicles the first subject of serious federal regulation of air pollution. Section 202(a) of the Motor Vehicle Air Pollution Control Act ${ }^{31}$ authorized the Secretary of Health, Education, and Welfare to prescribe "standards, applicable to the emission of any kind of substance, from any class or classes of new motor vehicles or new motor vehicle engines, which in his judgment cause or contribute to, or are likely to cause or contribute to, air pollution which endangers the health or welfare of any persons." 32 The criteria for setting such standards were very general: the Secretary was to give "appropriate consideration to technological feasibility and economic costs, ${ }^{\prime 33}$ and the effective date of the regulations was to be determined "after consideration of the period reasonably necessary for industry compliance." ${ }^{34}$ Acting under this authority, the federal government tended to adopt nationwide standards that had been tried before in California..$^{35}$

\section{B. Technology Forcing}

Dissatisfied with the slow pace of progress under the 1965 law, Congress in 1970 added a new section 202(b), requiring that emissions of hydrocarbons, carbon monoxide, and nitrogen oxides from new "light duty vehicles" be reduced by at least $90 \%$ from 1970 and 1971 levels by 1975 or (in the case of nitrogen oxides) by $1976 .{ }^{36}$

${ }^{30}$ See S. REP. No. 192, 89th Cong., 1st Sess, 5-6 (1965).

31 The entire Act was enacted as $\S 101(8)$ of the Clean Air Act Amendments of 1965, Pub. L. No. 89-272, 79 Stat. 992 (current version at 42 U.S.C. $\$ 7521$ (Supp. I 1977)).

${ }^{32}$ Id.

33 Id.

34 79 Stat. at 993.

${ }^{35}$ See 38 Fed. Reg. 10,317, 10,318 (1973): "In general, Federal standards have followed California standards by at least 1 full model year."

${ }_{36}$ Clean Air Act Amendments of 1970, Pub. L. No. 91-604, § 6(a), 84 Stat. 1690 (amending Clean Air Act $\S 202(b)(1)$ ) (current version at 42 U.S.C. $\$ 7521(b)(1)$ (Supp. I 1977)). Professor Rodgers has argued that these requirements were by no means as precise as they appeared, since "the Act invites discretion in fixing the baseline and measuring deviations from it." W. RODGERS, HaNDBOOK ON ENvirONMENTAL LAW \& 3.14, at 297 (1977). See also Jorling, The Federal Law of Air Pollution Control, in Federal Environmental Law 1058, 1114-15 (E. Dolgin \& T. Guilbert eds. 1974). The 1970 hydrocarbon standard was 2.2 grams per mile; the EPA, changing the test method, prescribed a 1975 standard of 0.41 . A judicial challenge failed because an emission measured at 2.2 grams per mile on the old test was measured at 4.1 on the new: "All the Administrator did, in effect was translate the 1970 emissions figures from the original test procedure into a more accurate procedure and calculate the 90 percent reduction according to the latter." Natural Resources Defense Council, Inc. v. Ruckelshaus, 359 F. Supp. 1028, 1030 (D.D.C. 1973). Thus, Professor Rodgers's conclu- 
These standards were to be "applicable" throughout the "useful life" of the vehicle, ${ }^{37}$ defined as five years or 50,000 miles, whichever came first. ${ }^{38}$

The new standards were dictated not by technological feasibility but by perceived need, in order to achieve projected ambient airquality standards in badly polluted areas. The needed reductions in emissions were determined by a simple "rollback" model based upon the proportional relationship between air quality and emissions: since carbon monoxide levels in Chicago were about five times the expected ambient standard, emissions would have to be cut by roughly a factor of five. ${ }^{39}$ It was explicitly recognized that the new standards could not be met with technology available in 1970:

The Secretary is expected to press for the development and application of improved technology rather than be limited by that which exists. In other words, standards should be a function of the degree of control required, not the degree of technology available .... [T] he committee concluded that 1975 would be the earliest possible date for application of the proposed standards . . . , based on recognition that technology may not be available to meet these standards within the next year and that the regular lead time which, in 1964, the industry indicated would be two years, should be supplemented by an

sion that the test revision "had the effect of relaxing actual emissions standards," W. RoDGERS, supra, $\S 3.14$, at 297 , seems to be true only in the nominal sense, for the regulations required 1975 emissions to be $90 \%$ less than those of 1970 .

More disturbing is his argument that the Administrator disobeyed the statute by taking as his baseline actual emissions from 1970 vehicles rather than those allowable under 1970 standards, and that the actual emissions were "considerably higher." W. RoDGERS, supra, $\$$ 3.14, at 297. The source Rodgers cites for this argument does not clearly establish it. While the EPA reported it had run "tests on 1970 model year vehicles," it did so in order to compare the two test procedures; its conclusion on hydrocarbons was that "the 1970 standards of 2.2 grams per vehicle mile . . . were equivalent to 4.6 grams per vehicle mile. . . using the new test procedure." 36 Fed. Reg. 3529 (1971) (emphasis added). The discrepancy between the 4.6 and 4.1 figures is explained by the development of still another test between 1972 and 1975. See also Ford Motor Co. v. EPA, 604 F.2d 685 (D.C. Cir. 1979) (holding it proper to limit nonreactive methane because it had been limited by the 1970 standards that were the basis of the required percentage reduction).

$\pi$ Clean Air Act Amendments of 1970, Pub. L. No. 91-604, § 6(a), 84 Stat. 1690 (amending Clean Air Act $\S 202(a)(1)$ ) (current version at 42 U.S.C. $\S 7521$ (a)(1) (Supp. I 1977)).

3* Id. 84 Stat. 1692 (amending Clean Air Act $\$ 202$ (d)(1)) (current version at 42 U.S.C. $\S$ 7521(d)(1) (Supp. I 1977)).

39 S. REP. No. 1196, 91st Cong., 2d Sess. 25 (1970). Allowances were made for growth in the number of automobiles and for the fact that older vehicles not subject to the new standards would remain in use for some years. 
additional period for the development of the control technology required . . . . ${ }^{40}$

The sanction, as under the original Act, was a prohibition on sale of vehicles not certified as meeting the standards, ${ }^{\text {, enforced by }}$ injunction upon suit by the United States, ${ }^{42}$ or by civil penalties, now of up to $\$ 10,000$ per vehicle. ${ }^{43}$ But the threat of a shutdown of the vital automotive industry for what might be an honest inability to come up with the requisite technology was so drastic as to be essentially incredible; Judge Leventhal spoke of "the reality that this authority would undoubtedly never be exercised"44 and noted that Senator Muskie, the bill's principal sponsor, had "stated quite clearly in the debate . . . that he envisioned the Congress acting if an auto industry shutdown were in sight." 45

\section{Postponements}

In fact Congress did provide an escape hatch, though of limited duration: upon proof that demanding conditions were satisfied, the EPA was authorized to suspend the statutorily required 1975 and 1976 standards "for one year," apparently with no right of renewal since "[n]othing in this provision shall extend the effective date of any emission standard ... for more than one year." 46

Affected manufacturers lost no time in applying for suspension of the 1975 hydrocarbon and carbon monoxide standards. After extensive litigation, ${ }^{47}$ the Administrator granted the suspension, setting two interim standards designed to require the use of catalytic converters only in California in order to "minimize initial production problems . . . while requiring each manufacturer to gain production experience preliminary to use of catalysts on all conventional engines during the 1976 model year."48 Further technological problems resulted in additional administrative suspensions in 1973

so Id. at 24, 27.

"Clean Air Act Amendments of 1970, Pub. L. No. 91-604, § 6(a), 84 Stat. 1693 (amending Clean Air Act $\$ 203(a)(1)$ ) (current version at 42 U.S.C. $\S 7522(a)(1)$ (Supp. I 1977)).

12 Id. $\S 7$ (b), 84 Stat. 1694 (amending Clean Air Act $\$ 204$ ) (current version at 42 U.S.C. $\S 7523$ (Supp. I 1977)).

t3 Id. $\S 7$ (c), 84 Stat. 1694 (amending Clean Air Act § 205) (current version at 42 U.S.C. $\S 7524$ (Supp. I 1977)).

" International Harvester Co. v. Ruckelshaus, 478 F.2d 615, 636 (D.C. Cir. 1973).

ss Id. (citing 116 CoNG. REc. 32,905 (1970)).

1t Clean Air Act Amendments of 1970, Pub. L. No. 91-604, § 6, 84 Stat. 1691 (amending Clean Air Act $\S 202(b)(5)$ ) (current version at 42 U.S.C. $\S 7521(b)(5)$ (Supp. I 1977)).

47 For a discussion of this litigation, see text and notes at notes 129-227 infra.

s* 38 Fed. Reg. 10,317, 10,319 (1973). 
and $1975^{49}$ and in a statutory extension in $1974 . .^{50}$ Further extensions were part of an extensive revision of the vehicle provisions in 1977.

\section{Light-Duty VehicLes}

\section{A. The Basic Emission Standards}

1. The Statutory Provisions. One of the principal motive forces behind the 1977 amendments to the Clean Air Act was the auto industry's urgent cry that further postponement of the light-dutyvehicle-emission standards was necessary to avoid a disastrous shutdown. ${ }^{51}$ Predictably, Congress extended the deadlines once again. Under section 202(b)(1)(A) the 90\% reduction of hydrocarbons, originally scheduled for 1975, was set for 1980 , and the like reduction of carbon monoxide was scheduled for $1981 . .^{52}$ The ultimate nitrogen oxide reduction was not only postponed but also substantively relaxed: while the 1970 statute would have set $\mathrm{NO}_{\mathrm{x}}$ emissions at 0.4 grams per mile by 1976 , the amended requirement is 1.0 by $1981 . .^{53}$ The new requirements are set out as follows in the Conference Report, subject to certain possibilities of waiver:

\section{EMISSIONS}

[Grams per mile]

\begin{tabular}{lccc} 
Model year & HC & CO & NO $_{\mathbf{x}}$ \\
\hline $1977-79$ & 1.5 & 15.0 & 2 \\
1980 & .41 & 7.0 & 2 \\
1981 and thereafter & .41 & 3.4 & 1 \\
\hline
\end{tabular}

SourCE: H.R. REP. No. 294, 95th Cong., 1st Sess. 166 (1977).

2. The Explanation. One searches the House Report in vain for a satisfactory explanation for these relaxations. The discussion is devoted almost entirely to a defense of the pre-existing standards: the technology was already available, the cost reasonable, the fuel penalty virtually nonexistent, the much-touted fear of increased

" In re Applications for Suspension of 1977 Motor Vehicle Exhaust Emission Standards, 7 Envir. Rep. Cas. 1593 (EPA 1975); 4 ENVIR. REP. (BNA) 577 (1973) (statement of EPA Acting Administrator on requested suspension of $1976 \mathrm{NO}_{\mathrm{X}}$ emission standards).

so Energy Supply \& Environmental Coordination Act of 1974, Fub. L. No. 93-319, \$ 5(b), 88 Stat. 258 (current version at 42 U.S.C. $\$ 7521$ (b) (Supp. I 1977)).

${ }^{31}$ See 8 Envir. ReP (BNA) 462-63, 509 (1977).

5242 U.S.C. $\S 7521$ (b)(1)(A) (Supp. I 1977).

ss Id. For a translation of the $90 \% \mathrm{NO}_{\mathrm{x}}$ requirement into grams per mile, see H.R. REP. No. 294, 95th Cong., 1st Sess. 233 (1977), reprinted in [1977] U.S. Code Cong. \& AD. News 1077, 1312. 
sulfuric acid emissions greatly exaggerated, the need great. ${ }^{54}$ The Report concedes that despite dramatic percentage reductions by 1977 in new-car emissions of hydrocarbons and carbon monoxide per mile, we had made little progress; because of increases in miles driven, EPA figures showed that "since 1970, the total hydrocarbon and carbon monoxide emissions from all automobiles on the road has decreased by a mere 14 percent and 16 percent, respectively. In the same period total automobile nitrogen oxide emissions have increased by 16 percent." 55

With respect to nitrogen oxides, the Report was particularly pessimistic: the EPA had found that "at all $N O_{x}$ standards greater than $.4 \mathrm{gram} / \mathrm{mile}$, the nitrogen dioxides levels will worsen by the year 2000,"58 that seven regions will exceed ambient $\mathrm{NO}_{\mathrm{x}}$ standards in 2000 if emissions are allowed to remain at $1.0 \mathrm{gram} / \mathrm{mile}$, and that "[a] reduction from $1.0 \mathrm{gram} / \mathrm{mile}$ to $0.4 \mathrm{gram} / \mathrm{mile}$ will result in approximately a 30 percent reduction" in "days of restricted activity due to lower respiratory disease in children." 57 Further, the National Academy of Sciences had found that "relaxation of the 0.4 $\mathrm{NO}_{\mathrm{X}}$ standard could preclude some large cities, and locations downwind from cities, from meeting the ambient oxidant [ozone] standards." 58

Yet the House Committee recommended extending the dates and relaxing the $\mathrm{NO}_{\mathrm{x}}$ standard to 1.0 , leaving it to the EPA to tighten the latter if necessary, and even the reference to tighter administrative standards was omitted in conference..$^{59}$ Ninetypercent $\mathrm{NO}_{\mathrm{X}}$ reduction-the pre-1977 standard-remains only a "research objective," with significant manufacturers required to build "demonstration vehicles" satisfying the objective by model year 1979.60

The Senate Report attempted to give reasons for the relaxing amendments. First, hydrocarbon and carbon monoxide extensions were based on "the time needed to integrate new emission control systems with fuel economy improvements, and to conclusively pre-

34 H.R. REp. No. 294, 95th Cong., 1st Sess. 231-71 (1977), reprinted in [1977] U.S. CodE Cong. \& AD. News at 1310-50.

ss Id. at 253, reprinted in [1977] U.S. Code Cong. \& AD. News at 1332.

ss Id. at 258 (emphasis in original), reprinted in [1977] U.S. CoDe Cong. \& AD. NEws at 1337.

${ }^{57}$ Id, at 259, reprinted in [1977] U.S. CODE CONG. \& AD. News at 1338.

58 Id, at 261, reprinted in [1977] U.S. CoDE Cong. \& AD. NEws at 1340.

39 H.R. REP. No. 564, 95th Cong., 1st Sess. 165-66 (1977), reprinted in [1977] U.S. Code Cong. \& AD. NEws 1502, 1545-47.

60 § 202(b)(7), 42 U.S.C. $\$ 7521(b)(7)$ (Supp. I 1977). 
clude, through testing, the creation of other unregulated emissions." 61 The Senate's proposed date was 1979; in conference it was revised to 1980 and 1981 without explanation. ${ }^{62}$ As for nitrogen oxides, the Committee noted that "the exact level of . . . control required for public health protection has been a matter of some debate" 163 and that implementation of a $1.0 \mathrm{gram} / \mathrm{mile}$ standard would reduce the fraction of $\mathrm{NO}_{\mathbf{x}}$ emissions attributable to lightduty vehicles from $32 \%$ to $16 \%$ by 1985.64 The Committee therefore concluded that "it is appropriate to place further emphasis on stationary sources ... while adopting a somewhat more moderate standard for autos." "65 Finally, "a major factor in the decision to alter the statutory $\mathrm{NO}_{\mathrm{x}}$ standard was the recognition that this would expand the technological options open to the auto industry." ${ }^{80}$ The $1980 \mathrm{NO}_{\mathrm{x}}$ date (also extended by a year in conference) was set "taking into account the necessary lead time . . . . In some cases the available technology . . . may require further development for efficient integration into the vehicle." 67

Whether the Senate Committee's cryptic conclusions and the additional unexplained conference extensions were correct I cannot say. If one agrees, as I do, that the problem of automotive pollution does not seem serious enough to call for shutting down the industry at once, only exhaustive review of the technical data can reveal whether the new delays were justified. The highly technical nature of the decision creates a significant risk of misunderstanding that is compounded when Congressmen with no special expertise and myriad responsibilities insist on resolving the question themselves. If we are to have administrative agencies at all, this seems the sort of decision they should be empowered to make.

\section{B. Additional Light-Duty Standards Under Section 202(a)}

1. Other Pollutants. The specific requirements for light-duty vehicles under section 202(b) apply only to emissions of hydrocarbons, carbon monoxide, and nitrogen oxides. Emissions of other pollutants remain subject to the rulemaking power of section 202(a),

\footnotetext{
" S. Rep. No. 127, 95th Cong., 1st Sess. 70 (1977).

62 H.R. Rep. No. 564, 95th Cong., 1st Sess. 165-66 (1977), reprinted in [1977] U.S. CoDE Cong. \& AD. NEws 1502, 1545-47.

ss S. Rep. No. 127, 95th Cong., 1st Sess. 70 (1977).

"Id.

as Id.

"Id.

${ }^{67}$ Id.
} 
essentially the original 1965 provision, ${ }^{68}$ under which the Administrator "shall" prescribe emission standards for "any air pollutant" from "new motor vehicles . . . which in his judgment cause[s], or contribute[s] to, air pollution which may reasonably be anticipated to endanger public health or welfare." ${ }^{69}$ Sufficient time is to be allowed "to permit the development and application of the requisite technology, giving appropriate consideration to the cost of compliance within such period." "ro

The Senate Committee in 1970 expressed the expectation that section 202(a) would be used "for regulation of particulate emissions," 71 and particulates are, in fact, the only contaminants other than those listed in section 202(b) for which vehicle-emission standards have even been proposed.72 Particulate standards existed only for heavy-duty diesels ${ }^{73}$ until 1979 , when the Agency proposed particulate standards for light-duty diesels as well. ${ }^{74}$

sx Compare Clean Air Act Amendments of 1965, Pub. L. No. 89-272, §101(8), 79 Stat. 992 (amending Clean Air Act $\$ 202(a)$ ) with Clean Air Act Amendments of 1977, Pub. L. No. 95-95, $\S 214(\mathrm{a}), 215,216,224(\mathrm{a}), 401(\mathrm{~d}), 91$ Stat. 751 (amending Clean Air Act $\S 202(\mathrm{a})$ ) (current version at 42 U.S.C. $\$ 7521$ (a) (Supp. I 1977)).

6) 42 U.S.C. $\$ 7521(a)(1)$ (Supp. I 1977). For the genesis and interpretation of this terminology, see text and notes at notes $487-530$ infra.

70 42 U.S.C. $\$ 7521$ (a)(2) (Supp. I 1977). Sections 202(a) and (b) are silent as to rulemaking procedure. The 1977 amendments, however, added a new and detailed provision for rulemaking procedure in section 307(d), which applies explicitly to "promulgation or revision of regulations under section [202]," 42 U.S.C. \& 7607(d)(1)(J) (Supp. I 1977), and to many other rulemaking activities. Its requirements will be discussed in detail in a subsequent article.

"S. REP. No. 1196, 91st Cong., 2d Sess. 24 (1970).

72 Emission standards for lead were considered and rejected in favor of limiting the lead content of gasoline, since section 202(a) authorizes standards only for new vehicles. See note 506 infra.

7340 C.F.R. $\$ \S 86.077-11$ (1978).

"4 44 Fed. Reg. 6650 (1979). In proposing the light-duty diesel standards, the EPA quite unnecessarily invoked the authority of section 203(a)(3)(A)(iii), added in 1977, which requires the Administrator to prescribe particulate emissions based on best practicable technology for "classes and categories of vehicles manufactured during and after model year 1981," 42 U.S.C. $\$ 7521(\mathrm{a})(3)$ (A)(iii) (Supp. I 1977). Despite the apparently all-embracing reference in this provision to "vehicles," the structure of the statute and its history suggest that the EPA's reliance may have been misplaced. All the other paragraphs of section 202(a)(3), in which the particulate provision appears, expressly apply only to heavy-duty vehicles. See text and notes at notes $266-270$ infra. The House bill had no particulate provision, and its section 202(a)(3) dealt solely with heavy-duty vehicles and with motorcycles. See H.R. REP. No. 294, 95th Cong., 1st Sess. 407-09 (1977). The Senate bill, on the other hand, contained a single provision, applicable only to heavy-duty vehicles and to motorcycles, that treated particulates precisely as it did hydrocarbons, nitrogen oxides, and carbon monoxide. See $\mathrm{S}$. REP. No. 127, 95th Cong., 1st Sess. 193-94 (1977). In engrafting the Senate's particulate requirement onto the basic framework of the House bill, the Conference Committee made it a separate provision, reformulated the criteria for setting particulate standards, and left out the explicit limitation to heavy-duty vehicles and motorcycles. The Conference Report, in a discussion 
The proposed standards are based on available technology as applied to the worst emitters among current vehicles; they are expected to add $\$ 285$ to the price of affected vehicles by 1983 , offset in part by increased fuel economy. ${ }^{75}$ Gasoline-powered vehicles are excluded from both sets of particulate regulations since the EPA viewed particulate emissions from gasoline engines as trivial. ${ }^{76}$

2. Nonexhaust Emissions. The section 202(b) standards, though phrased as limits on "emissions," are understood to refer to exhaust emissions. ${ }^{77}$ But acting under section 202(a), the Administrator has also forbidden all light-duty "crankcase emissions" and has limited evaporative emissions of hydrocarbons from such vehicles to "6.0 grams per test," by $1981 .{ }^{79}$

3. Tightening the Statutory Standards. Even for emissions covered by the numerical requirements of section 202(b), the Senate Committee was explicit that the Administrator retained authority "to set standards more stringent than those established in the statute." ${ }^{80}$ With respect to hydrocarbons and carbon monoxide, it is clear from section 202(b) itself that after 1979 and 1980 the EPA can promulgate more stringent standards, for the standards "under subsection (a)" are to require a reduction of "at least 90 percent."'

entitled "Heavy Duty Vehicles and Other Vehicles," H.R. REP. No. 564, 95th Cong., 1st Sess. 162 (1977), reprinted in [1977] U.S. CoDE CoNG. \& AD. News 1502, 1542-43, (followed by a separate discussion on "Light Duty Motor Vehicle Emissions," id. at 163, reprinted in [1977] U.S. CoDE CoNG. \& AD. NEws at 1543-44) says only that the statute "requires the Administrator to promulgate particulate standards based on criteria set forth in the House interim standards provision." Id. at 162, reprinted in [1977] U.S. CoDE CoNG. \& AD. NEws at 154243.

Given the rule that the conference committee is authorized only to reconcile differences between the Houses, Union Elec. Co. v. EPA, 427 U.S. 246, 262-63 (1976), this history seems to establish that the statute should not be construed to include a requirement of light-duty particulate standards that was found in neither bill. The "vehicles" for which there must be such standards are thase with which section 202(a)(3) is concerned, namely heavy-duty vehicles. The regulation of particulates from light-duty vehicles, however, is sustainable under the general authority of section 202(a)(1).

7544 Fed. Reg. 6650, 6652 (1979).

76 "[D]iesel-fueled engines emit approximately 40 times the amount of particulate that is emitted by gasoline-fueled engines equipped with catalytic converters." Id. at 6650 .

${ }^{77}$ See, e.g., 40 C.F.R. \& 86.078-8(a) (1978).

${ }^{78}$ Id. $\S 86.078-8(\mathrm{~b})(1)(\mathrm{i})$.

7 43 Fed. Reg. 37,970 (1978) (adding 40 C.F.R. $\$ 86.081-8$ ). See $\S 202(b)(1)$ (c), 42 U.S.C. $\S 7521(b)(1)(C)$ (Supp. I 1977) (prescribing that for 1978 and later light-duty vehicles evaporative emissions "be measured from the vehicle or engine as a whole"); § 202(a)(6), 42 U.S.C. $\$ 7521(a)(6)$ (Supp. I 1977) (requiring the EPA to prescribe "onboard hydrocarbon control technology" if it proves preferable to gasoline vapor recovery by the gas-station operator as a means of reducing evaporative emission during filling). Both were added in 1977.

so S. Rep. No. 127, 95th Cong., 1st Sess. 75 (1977).

st 42 U.S.C. $\$ 7521(\mathrm{~b})(1)(\mathrm{A})$ (Supp. I 1977) (emphasis added). 
For earlier years and for nitrogen oxides the statute is ambiguous: regulations under subsection (a) "shall contain standards which provide that such emissions . . . may not exceed" a given number of grams per mile. ${ }^{82}$ Since the nitrogen oxide provision of the bill on which the Senate Committee was commenting contained language identical to that in section $202(\mathrm{~b}),{ }^{83}$ the Committee's interpretation should be persuasive that section 202(b) as ultimately adopted merely sets a ceiling and does not require that the standard be set at the specified figure.

4. The Relevance of Technology and Cost. In explaining the omission of the pre-1970 requirement that the Administrator give "appropriate consideration to technological feasibility and economic costs" in setting standards under section 202(a), the Senate Report observed that standards "should be a function of the degree of control required, not the degree of technology available today." This passage may suggest more than it actually says, for the statute still requires that in setting the implementation date for standards, the Administrator allow sufficient time "to permit the development and application of the requisite technology, giving appropriate consideration to the cost of compliance within such period." 85 The Senate Committee was arguing for technology-forcing standards, ${ }^{86}$ not contradicting the statutory command that technology and cost be considered in determining the date of compliance. As Professor Rodgers said, "the technical and economic factors banished in developing the standards are imported into the equation in determining time for compliance." to take technology and cost into account in setting each year's standards under section $202(a) .88$

\section{The Definition of Light-Duty Vehicles}

The statute unhelpfully defines "light duty vehicles and engines" to mean "new light duty motor vehicles and new light duty motor vehicle engines, as determined under regulations of the Ad-

${ }^{\times 2}$ Id. $\S 7521(\mathrm{~b})(\mathrm{l})(\mathrm{A})-(\mathrm{B})$ (emphasis added).

* S. ReP. No. 127, 95th Cong., 1st Sess. 194-95 (1977).

* S. REP. No. 1196, 91st Cong., 2d Sess. 24 (1970).

* 42 U.S.C. \& 7521(a)(2) (Supp. I 1977).

s8 "The Secretary is expected to press for the development and application of improved technology rather than be limited by that which exists." S. REP. No. 127, 95th Cong., Ist Sess. 75 (1977).

${ }^{87}$ W. RoDGERs, supra note $36, \S 3.14$, at 296.

kx See, e.g., 43 Fed. Reg. 37;970 (1978) (evaporative emissions from light-duty trucks). 
ministrator." 89 The Administrator, in substantial accord with regulations antedating the use of the term in the statute,,$^{y 0}$ defined a light-duty vehicle as one "either designed primarily for transportation of property and rated at 6,000 pounds [gross vehicle weight] or less or designed primarily for transportation of persons and having a capacity of 12 persons or less."91

Pursuant to this definition, small trucks and recreational vehicles were subjected to the stringent section $202(\mathrm{~b})$ standards for "light duty vehicles." In International Harvester Co. $v$. Ruckelshaus, ${ }^{92}$ the District of Columbia Circuit pointed out that requiring small trucks to meet automotive standards would make it impossible for such vehicles to haul large loads..$^{93}$ It therefore held the definition too broad. Despite the clear delegation of authority to define "light duty vehicles," the court concluded that the "legislative history reveals this term to mean 'passenger cars." "פ, The Senate Committee, for example, had spoken of "standards for light duty motor vehicles (passenger cars)." ${ }^{95}$ Accordingly, the court held that light trucks were not "light duty vehicles" within section 202(b) and directed the Agency to reconsider the status of "multipurpose passenger vehicles," such as jeeps and campers, which also carry heavy loads but which "largely overlap in their usage with passenger cars." ${ }^{96}$ On remand the EPA exempted these too. ${ }^{97}$ With small trucks, they are now subject to separate standards adopted under section $202(\mathrm{a}) .^{98}$

\section{High-Altitude Provisions}

High altitude, it appears, commonly has an adverse effect upon automotive emission control. Consequently, the EPA adopted a regulation requiring that cars and light trucks to be sold above 4,000 feet be shown to meet the emission standards at that altitude..$^{99} \mathrm{As}$ a result, in 1977 "only 50 percent of all car models were available

\footnotetext{
" § 202(b)(3)(B), 42 U.S.C. § 7521(b)(3)(B) (Supp. I 1977).

so See International Harvester Co. v. Ruckelshaus, 478 F.2d 615, 639 n.87 (D.C. Cir. 1973).

" 36 Fed. Reg. 22,448, 22,449 (1971).

?2 478 F.2d 615 (D.C. Cir. 1973).

${ }^{93}$ Id. at 639 .

"Id.

's Id. (citing S. Rep. No. 1196, 91st Cong., 1st Sess. 24 (1970)).

" 478 F.2d at 640.

"7 38 Fed. Reg. 10,317, 10,328 (1973).

* See text and notes at notes 271-284 infra.

" 40 C.F.R. $\$ 86.077-30$ (a)(4) (1978).
} 
in the high-altitude areas covered by the regulations."100

Congress therefore gave dealers and customers of cars sold above 4,000 feet a break in the 1977 amendments. While by 1984 "[a]ll light duty vehicles and engines ... shall comply with the requirements of section [202] . . regardless of the altitude at which they are sold,"101 the EPA's 1977 high-altitude regulation ${ }^{102}$ - which makes applicable gram-per-mile standards for $\mathrm{CO}, \mathrm{HC}$, and $\mathrm{NO}_{\mathrm{x}}$-is explicitly made inapplicable to 1978 and later vehicles; the Agency is forbidden to make "[a]ny future regulation affecting the sale or distribution of motor vehicles or engines . . . in high altitude areas" applicable before the 1981 model year; ${ }^{103}$ and no such regulation for 1981-1983 may require "a percentage of reduction ... which is greater than the required percentage . . . in subsection (b)" or establish "a numerical standard which is more stringent" than that applicable at low altitudes. ${ }^{104}$

By imposing nationally uniform emission limitations in grams per mile, the EPA had created hardship in high-altitude areas. But by forbidding the Agency to make any special high-altitude provision for three model years, Congress leaves breathers in those areas with no assurance that they will benefit from the tighter standards otherwise mandated by section 202(b). As the Senate Committee conceded, until the high-altitude regulations were adopted "urban high altitude areas requiring transportation controls in order to reach the public health standards were not even getting the benefit of cleaner cars. The severe problem of cities such as Denver has been exacerbated, despite the installation of emission control technology."105

Whether Congress's decision for 1978-1980 is a sound one cannot be answered without more information about the effect of high altitude on auto emissions. One hopes the impact is slight; otherwise Congress in the short run has sacrificed the comfort of all people in smoggy high areas to which Judge Leventhal in Inter-

${ }^{100}$ S. REP. No. 127, 95th Cong., 1st Sess. 87 (1977).

$101 \S 206(f)(1), 42$ Ü.S.C. $\$ 7525(f)(1)$ (Supp. I 1977).

10240 C.F.R. \& 86.077-310(9)(4) (1978).

$103 \S 202$ (f)(1), 42 U.S.C. \& 7521(f)(1) (Supp. I 1977).

tot § 202(f)(2), 42 U.S.C. \$ 7521(f)(2) (Supp. I 1977). Subparagraph (3) of this section makes applicable to the adoption of such regulations the rulemaking procedure of section 307 (d) and specifies factors to be taken into account in setting such a regulation. "High altitude" is not defined; the Senate Committee, without appearing to attempt to prescribe, said the statute would require a test at "a high altitude specified by regulation (presumably 4,000 feet)," the level specified in the 1977 regulation. S. REP. No. 127, 95th Cong., 1st Sess. 87 (1977).

105 S. Rep. No. 127, 95th Cong., 1st Sess. 88 (1977). 
national Harvester pungently characterized as "the driving preferences of hot rodders."106

For the 1981-1983 period the EPA may do something about high-altitude emissions, but within limits. It was the evident inability to achieve the same gram-per-mile emission levels at high as at low altitudes that caused the shortage of models at high altitudes; thus it makes sense that in absolute terms high-altitude limits may not be more stringent. Equity seemingly accounts for the additional requirement that no greater percentage reductions be required at high than at low altitudes, as would the fact, if established, that technology does not permit greater percentage reductions at high altitudes. ${ }^{107}$

The statute's requirement that by 1984 all cars meet "the requirements of section [202]"108 regardless of altitude is ambiguous, since for two pollutants ( $\mathrm{CO}$ and $\mathrm{HC}$ ) that section prescribes percentage reductions, ${ }^{109}$ while for the third $\left(\mathrm{NO}_{\mathrm{x}}\right)$, as the $1977 \mathrm{EPA}$ regulations do for all three, it imposes a standard in grams per mile. ${ }^{110}$ On the face of the statute, the 1984 provision arguably could be satisfied for carbon monoxide and hydrocarbons if the regulations required equal percentage reductions at all altitudes. But such a construction would arguably depart from the Senate Committee's purpose to afford all areas "the same cleanup benefit" and from its paraphrase of the provision as requiring that all models comply "with applicable emission standards."'11 These passages may seem to suggest that Congress intended, as under the 1977 EPA regulation, to require compliance with uniform performance standards at all altitudes in grams per mile.

$10 \times 478$ F.2d at 640 .

107 I suspect the effect of the limitation will be to forbid greater percentage reductions at high than at low altitudes, though the actual basis of comparison is the percentage reduction "as set forth in subsection (b)," not that actually applicable at low altitudes. $\S 202(f)(2), 42$ U.S.C. $\$ 7521$ (f)(2) (Supp. I 1977). In theory these might differ: while the percentages "set forth in subsection (b)" for 1981-1983 are $90 \%$ for carbon monoxide and hydrocarbons, the regulations are to require "at least" that degree of reduction. Apparently $90 \%$ is to be the limit of $\mathrm{HC}$ and $\mathrm{CO}$ reduction required at high altitude even if a greater reduction is required elsewhere. Although a requirement exceeding $90 \%$ in those years may be unlikely, I do not see why, without a showing that altitude affects the percentage reduction achievable, Congress should have made such a distinction.

$108 \S 206(f)(1), 42$ U.S.C. § 7525(f)(1) (Supp. I 1977).

in $\S 202(\mathrm{~b})(1)(\mathrm{A}), 42$ U.S.C. $\$ 7521$ (b)(1)(A) (Supp. I 1977).

u1 $\S 202(\mathrm{~b})(1)(B), 42$ U.S.C. $\& 7521(\mathrm{~b})(1)(B)$ (Supp. I 1977).

"I S. REP. No. 127, 95th Cong., 1st Sess. 87 (1977). While the dates in the Senate bill were different from those ultimately adopted, the same reference was made to "the requirements of section 202," which in that bill also combined percentage and performance requirements, at the time phrased in grams per mile. Id. at 194-95, 203. 
This interpretation sounds attractive as a means of assuring the necessary degree of control at high altitudes. Yet it may prove undesirably rigid. Although the statutory levels were chosen because of their relation to public health, the calculations were not made with high-altitude conditions in mind and were derived from a rollback model that seemed to focus on percentage reductions. ${ }^{112}$ These calculations do not by themselves prove that identical performance standards are needed to achieve the same beneficial effects at high altitudes. Conversely, the requirement of uniformity fails to allow for the possibility that continuing technological disparities may make it impossible to achieve identical high- and low-altitude standards. In other words, the uniformity requirement may in effect mean that the EPA cannot require stricter controls at sea level, however feasible and necessary, unless they are also feasible in other places where they may not be needed.

It should be noted that the 1977 regulation applied only to light-duty vehicles and to light trucks, not to heavy-duty vehicles; ${ }^{113}$ that the prohibition on special high-altitude requirements before 1981 and the limits on later regulations apply to all vehicles; ${ }^{114}$ and that the 1984 equality provision reaches only "light duty vehicles." "115 High-altitude regulations for other vehicles in 1984 and later years will be determined by the Administrator subject to the limitations applicable to all vehicles in 1981-1983. This may mean that what the statute requires as to cars it forbids as to trucks, for in the case of the latter no greater percentage reduction may be required at high than at low altitude. I see no justification for such an inconsistency.

\section{E. Waiver Provisions}

1. Nitrogen Oxides. Three safety valves are provided in the 1977 amendments for further administrative relaxation of the nitrogen oxides standard of section 202(b). The first, in section 202(b)(1)(B), allows the relatively small manufacturer (fewer than 300,000 vehicles worldwide in 1976) up to 2 grams per mile until 1983 on a showing that he is "dependent upon technology developed by other manufacturers" and "lacks the financial resources and technological ability to develop such technology." 116 The other two,

\footnotetext{
112 See S. REP. No. 1196, 91st Cong., 1st Sess. 25-27 (1970).

is 40 C.F.R. $\$ 86.077-30(\mathrm{a})(4)$ (1978).

III $\S 202(f)(1)-(2), 42$ U.S.C. $\S 7521(f)(1)-(2)$ (Supp. I 1977).

113 $\S 206(f)(1), 42$ U.S.C. $\$ 7525(f)(1)$ (Supp. I 1977).

11842 U.S.C. $\$ 7521$ (b)(1)(B) (Supp. I 1977). American Motors Corporation was granted
} 
in sections 202(b)(6)(A) and (B), ${ }^{117}$ allow any manufacturer up to 1.5 grams per mile for as many as four years if he can demonstrate that the exemption will encourage, respectively, the development of an "innovative power train technology, or innovative emission control device or system" or "the use of diesel engine technology," the latter of which was viewed as "a very useful means of meeting fuel economy requirements."118

In either of these latter two cases the Administrator must find that a waiver will "not endanger public health" and that the technology involved "has a potential for longterm air quality benefit and has the potential to meet or exceed" applicable fuel-economy standards at the end of the waiver. ${ }^{119}$ In addition, a diesel waiver may be granted only if there promise to be "significant fuel savings at least equal to the fuel economy standard applicable in each year," 121 and other innovative waivers only if "there is a substantial likelihood that the vehicles will be able to comply with the applicable $\left[\mathrm{NO}_{\mathrm{X}}\right]$ standard . . . at the expiration of the waiver."121 The latter may be granted for no more than " 5 percent of such manufacturer's production or more than fifty thousand vehicles or engines, whichever is greater."122 "Opportunity for public hearing" is required for innovative and diesel waivers; $;^{123}$ nothing is said of procedure respecting the small-manufacturer extension of section 202(b)(1)(B).

These waiver provisions appear to allow for sensible minor adjustments to the overall statutory plan, and they rightly leave it to the Agency to determine whether the statutory policies are in fact satisfied. Somewhat uncertain in its impact is the understandable insistence that there be no danger to public health. Since ambient levels of both nitrogen oxides and oxidants exceeded health-related levels in many areas when the amendments were adopted, ${ }^{124}$ a strict interpretation of the health requirement might render the waiver provisions entirely nugatory. It would seem more consistent with congressional expectations to read the proviso as requiring that the

a waiver in August, 1979. 44 Fed. Reg. 47,780, 47,884 (1979) (amending 40 C.F.R. $\$ 86.081$ 8(iii)).

11742 U.S.C. § 7521(b)(6)(A)-(B) (Supp. I 1977).

"1s H.R. REP. No. 294, 95th Cong., 1st Sess. 249 (1977), reprinted in [1977] U.S. CoDE Cong. \& AD. News 1077, 1328.

119 § 202(b)(6)(A)-(B), 42 U.S.C. $\S 7521(\mathrm{~b})(6)(\mathrm{A})$-(B) (Supp. I 1977).

$120 \S 202(\mathrm{~b})(6)(B)(\mathrm{ii}), 42$ U.S.C. $\S 7521$ (b)(6)(B)(ii) (Supp. I 1977).

i21 § 202(b)(6)(A)(ii), 42 U.S.C. \& 7521(b)(6)(A)(ii) (Supp. I 1977).

$122 \S 202(\mathrm{~b})(6)(\mathrm{A})(\mathrm{iii}), 42$ U.S.C. $\S 7521(\mathrm{~b})(6)$ (A)(iii) (Supp. I 1977).

$123 \S 202(\mathrm{~b})(6)(\mathrm{A})-(\mathrm{B}), 42$ U.S.C. $\$ 7521(\mathrm{~b})(6)(\mathrm{A})$-(B) (Supp. I 1977).

i2 See H.R. ReP. No. 294, 95th Cong., 1st Sess. $207-08$ (1977), reprinted in [1977] U.S. Code Cong. \& AD. News 1077, 1286-87. 
waiver itself not significantly exacerbate the existing health dangers; the EPA does so interpret it. ${ }^{125}$

2. Carbon Monoxide. More complicated provisions in section 202(b)(5), derived from earlier sections under which previous extensions were granted, authorize the Administrator "after public hearing" to allow up to 7.0 grams per mile of carbon monoxide-twice the statutory standard-during model years 1981 and 1982. ${ }^{126}$ The criteria for this waiver are quite demanding:

The Administrator may grant such waiver if he finds that protection of the public health does not require attainment of such 90 percent reduction for carbon monoxide for the model years to which such waiver applies in the case of such vehicles and engines and if he determines that-

(i) such waiver is essential to the public interest or the public health and welfare of the United States;

(ii) all good faith efforts have been made to meet the standards established by this subsection;

(iii) the applicant has established that effective control technology, processes, operating methods, or other: alternatives are not available or have not been available with respect to the model in question for a sufficient period of time to achieve compliance prior to the effective date of such standards, taking into consideration costs, driveability, and fuel economy; and

(iv) studies and investigations of the National Academy of Sciences conducted pursuant to subsection (c) of this section and other information available to him has not indicated that technology, processes, or other alternatives are available (within the meaning of clause (iii)) to meet such standards. ${ }^{127}$

No similar provision was made for hydrocarbons or nitrogen oxides. Presumably, though the reports do not say so, Congress thought there was less doubt that the requisite technology for those pollutants would be available in time.

In September 1979, the Administrator granted waivers of the 1981-1982 CO standards for certain vehicle models and denied waivers for others. ${ }^{128}$

\footnotetext{
${ }^{125}$ See 43 Fed. Reg. 30, 31 (1978).

12842 U.S.C. $\$ 7521(\mathrm{~b})(5)(\mathrm{A})$-(B) (Supp. I 1977).

127 Id. $\S 7521(\mathrm{~b})(5)(\mathrm{C})$.

${ }^{123} 44$ Fed. Reg. 53,376 (1979).
} 
With two exceptions discussed below, the criteria for a carbon monoxide waiver under section 202(b)(5) are identical to those in force when the Court of Appeals for the District of Columbia Circuit passed upon the Administrator's initial denial of a suspension of 1975 requirements in International Harvester Co. $v$. Ruckelshaus. ${ }^{124}$ That opinion therefore sheds considerable light on the meaning of the current provisions.

a. Unavailable Technology. The central focus of the International Harvester litigation was on the requirement, now in paragraph (iii), that the necessary technology not be available in time to permit compliance. In requesting a waiver, the manufacturers pointed out that only one of the 500 test vehicles had met the standards, and that none had actually been driven the requisite 50,000 miles. But the EPA denied the suspension, predicting that catalytic converters would make compliance possible in time for 1975 production. Taking a close look at the record, the court remanded for further proceedings on the ground that the Agency had relied on several inadequately established assumptions. In the course of the opinion, however, the court settled several propositions of general significance.

i. Forecasting, Model Diversity, and Catalyst Replacement. First, the court held, the EPA was right that denial of a suspension was permissible although the technology was not fully developed at the time of the application; since manufacturers had "admitted that technological improvements can continue during the two years prior to production," it was permissible to predict improvements, "subject to the restraints of reasonableness" and "limited by relevant considerations of lead time needed for production." 130 There is some difficulty in squaring this result with the statutory reference to technologies that "are" or "have . . . been"131 available, which seems to speak to the time of the waiver decision; but the court surely was faithful to the congressional purpose as reflected in the further words "a sufficient period of time to achieve compliance prior to the effective date of such standards." 132

The court also held in International Harvester:

We are inclined to agree with the Administrator that as long as feasible technology permits the demand for new passenger

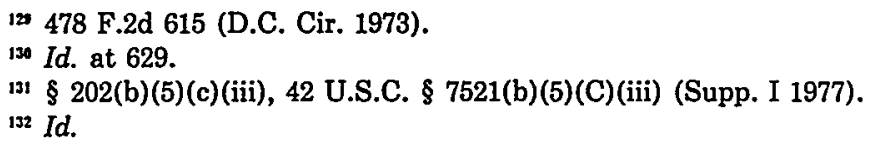


automobiles to be generally met, the basic requirements of the Act would be satisfied, even though this might occasion fewer models and a more limited choice of engine types. The driving preferences of hot rodders are not to outweigh the goal of a clean environment. ${ }^{133}$

As the statute stood at the time, this seemed a reasonable interpretation, for the statute required a showing that the requisite technology was not "available" without specifying for which models. ${ }^{134}$ The 1977 amendments, however, revised the language to permit waiver on proof that the technology was unavailable "with respect to the model in question." 135 The Agency accordingly appeared to depart from the International Harvester interpretation in granting 19811982 waivers under the revised provision, despite the availability of technology for other models, in order to preserve competition and avoid unemployment. ${ }^{138}$

In this last decision the Administrator also resolved an additional question of significance with respect to the availability of technology. Certain models, he found, could be made to meet the standards by replacement of the catalyst once during the statutory period of "useful life." Nevertheless he granted the waiver as to these models, plausibly reasoning that the likelihood that the consumer would neglect to make the replacement rendered the technology not "effective," as required by the statute. ${ }^{137}$

ii. Cost. As enacted in 1970, the suspension provision made no mention of excessive cost, of impaired performance, or of harmful emission of other pollutants; ${ }^{138}$ arguably the statute forbade an extension, so long as technology was "available" to achieve the standard, even if its use would cause a 50\% drop in fuel economy, double the price of automobiles, and poison passers-by with horrible metals.

Predictably, when it was feared that catalytic converters created a risk of harmful sulfuric acid emissions, the Administrator found a way to grant another extension. The statute required that "effective" technology be available, and "Congress could not have

133478 F.2d at 640 .

33 Clean Air Act Amendments of 1970, Pub. L. No. 91-604, § 6(a), 84 Stat. 1691 (amending Clean Air Act $\S 202(b)(5)(C)$ ) (current version at 42 U.S.C. $\$ 7521(b)(5)(C)$ (iii) (Supp. I 1977)).

${ }_{133} \S 202(\mathrm{~b})(5)(\mathrm{C})(\mathrm{iii}), 42$ U.S.C. \& 7521(b)(5)(C)(iii) (Supp. I 1977).

${ }_{136} 44$ Fed. Reg. $53,376,53,378,53,382-83$ (1979).

${ }^{137} \mathrm{Id}$. at $53,376,53,377,53,380-81$.

${ }^{138}$ Clean Air Act Amendments of 1970, Pub. L. No. 91-604, § 6(a), 84 Stat. 1691 (amending Clean Air Act $\S 202(b)(5)$ ) (current version at 42 U.S.C. $\S 7521(b)(5)$ (Supp. I 1977)). 
intended that 'effective' would describe a technology that did more harm to public health in one aspect than it prevented in another."139 Thus did administrative common sense compensate for inept drafting; the EPA might easily have concluded, and perhaps ought to have concluded, that Congress, as is its prerogative, had meant to do something quite foolish.

Fortunately, the 1977 amendments confirm the Agency's interpretation by adding that the determination of availability under paragraph (iii) is to be made "taking into consideration costs [which should be read broadly to include environmental ones ${ }^{140}$ ], driveability, and fuel economy." ${ }_{141}$ Unfortunately, the EPA has chosen to give costs a rather minimal consideration that may be inconsistent with the statute. In denying waivers of certain 1981-1982 models, the Administrator stated that cost renders technology unavailable only if it is so great as "to make the engine family unable to remain reasonably competitive in the marketplace." ${ }^{142}$ I should have thought "taking [costs] into consideration" meant determining whether the costs were unreasonable when compared with the benefits.

As redefined to incorporate costs, the unavailability of technology remains a necessary but not sufficient ground for suspension.

b. NAS Study. A second and somewhat vague requirement for suspension, in paragraph (iv), is that a study by the National Academy of Sciences (NAS) and "other information available" to EPA "has not indicated" that the technology is available. ${ }^{143}$ Perhaps this means only that the EPA is to consider the NAS report in determining whether technology is available, but that it is stated as an independent requirement lends strength to the startling conclusion that Congress has given a quasi-public association an unreviewable veto power. ${ }^{144}$ If an extension is in the public interest, the statute should

133 In re Applications for Suspension of 1977 Motor Vehicle Exhaust Emission Standards, 7 Envir. Rep. Cas. 1593, 1597 (EPA 1975). Cf. Portland Cement Ass'n v. Ruckelshaus, 486 F.2d 375, 385 (D.C. Cir. 1973) (holding that references to "the best . . . system of emission ... reduction" and to "the cost of achieving such reduction" in section 111 of the Act (current version at 42 U.S.C. $\$ 7411$ (a)(1) (Supp. I 1977)), "require the Administrator to take into account counter-productive environmental effects of a proposed standard").

wo See Portland Cement Ass'n v. Ruckelshaus, 486 F.2d 375, 385 (D.C. Cir. 1973).

u1 $\S 202$ (b)(5)(C)(iii), 42 U.S.C. § 7521(b)(5)(C)(iii) (Supp. I 1977).

142 44. Fed. Reg. 53,376, 53,381, 53,385 (1979).

its $\S 202(\mathrm{~b})(5)(C)(i v), 42$ U.S.C. $\S 7521(\mathrm{~b})(5)(\mathrm{C})(\mathrm{iv})$ (Supp. I 1977).

is The court of appeals seems to have agreed in dictum with the latter interpretation: "The statute makes the NAS conclusion a necessary but not sufficient condition of suspension." 478 F.2d at 649 . In granting the 1975 extension after remand in International Harvester, the Administrator ducked the veto issue. Although NAS had flatly reported that "vehicles incorporating certified systems 'can be mass-produced in great enough volume to satisfy, in 
require it to be granted, whether or not the NAS agrees.

c. Public Interest. Paragraph (i) imposes the additional requirement that the waiver be "essential to the public interest or the public health and welfare." 145 Since the theoretical consequence of inability to meet the standards may be a catastrophic limitation of auto production, a public-interest finding may be virtually inevitable if the technology is not available; yet making the requirement clear in the statute properly focuses attention on the benefits as well as on the costs of compliance. ${ }^{146}$

d. Good Faith. The final criterion of the 1970 statute, ${ }^{147}$ preserved in paragraph (ii) of the 1977 amendments, was that "all good faith efforts have been made to meet the standards." 148 In principle, this limitation is attractive. In practice, the severity of possible consequences of denying a waiver promises to make it essentially unenforceable. ${ }^{148}$

On remand from the International Harvester decision, for example, the Administrator expressed doubts as to Chrysler's good faith: Chrysler expenditures for emission-control research, per dollar of sales volume, had been about a third of those of Ford or of General Motors; ;50 Chrysler had changed plans when rather well along, making "certain sacrifices in the progress of its technology . . . to achieve cost savings"; ${ }^{151}$ and a catalyst manufacturer had testified that Chrysler had refused to buy its product "for reasons materially influenced by the aggressive testimony of [the supplier] . . . at the EPA hearings last year." 152 Yet because of the serious consequences of a suspension denial on large numbers of innocent

aggregate, the expected demand for vehicles in model year 1975," "the Administrator affected to find NAS in agreement with his own conclusion: "The NAS itself admitted that there is a chance that a significant number of engine families would not certify and did not deny that production problems were a significant possibility . . . " 38 Fed. Reg. 10,317, 10,325 (1973). Once again the Agency appears to have given short shrift to a statutory requirement that could interfere with rational administration if taken seriously.

$115 \S 202(b)(5)(C)(i), 42$ U.S.C. $\& 7521(b)(5)(C)(i)$ (Supp. I 1977).

14 On remand from International Harvester, the Administrator found the risk of failure in mass production decisive in light of its adverse effects on the automobile industry. 38 Fed. Reg. 10,318 (1973).

${ }_{147}$ Clean Air Act Amendments of 1970, Pub. L. No. 91-604, $\S$ 6(a), 84 Stat. 1692 (amend- , ing Clean Air Act $\S 202(b)(5)(D)(i i)$ (current version at 42 U.S.C. $\$ 7521$ (b)(5)(C)(ii) (Supp. I 1977)).

us § 202(b)(5)(C)(ii), 42 U.S.C. § 7521(b)(5)(C)(ii) (Supp. I 1977).

149 See W. RodGers, supra note $36, \S 3.14$, at 299 : "The devastating impact of a finding of bad faith for all practical purposes assures the extinction of the provision."

13038 Fed. Reg. 10,317, 10,327 (1973).

131 Id. at 10,328 .

${ }^{152}$ Id. at 10,327. 
people, the Administrator nevertheless concluded "with serious reservations" that Chrysler had acted in good faith. ${ }^{153}$

e. Public Health. The 1977 amendments, without committee explanation, add still another requirement: the Administrator must find "that protection of the public health does not require attainment of such 90 percent reduction for carbon monoxide for the model years to which such waiver applies."154 Since the statute already required that the waiver be "essential to the public interest or the public health," 155 one might think the additional health requirement superfluous. In any case, the presence of the publicinterest requirement seems to suggest that the health provision means something other than a mere balancing of health concerns against risk of shutdown, since this much was implicit in "public interest." The resulting inference is that Congress meant to forbid an extension absolutely, without regard to this balance, if failure to meet the standard would be harmful to public health.

I have elsewhere criticized the tendency to require absolute health protection without regard to cost, ${ }^{156}$ and the evident decision to do so in the waiver provision seems inconsistent with the decision, in the same amendments, to extend the deadline for meeting basic emission standards despite predictions that health hazards will continue. ${ }^{157}$ 'The EPA's interpretation of the health requirement, which tracks its reading of the innovative $N O x$ waivers, ${ }^{158}$ somewhat reduces the problem: the question is not whether ambient levels after the waiver will be harmful, but whether they will be significantly more harmful than if the statutory standard were complied with. ${ }^{159}$ Even so construed, the health requirement makes less sense here than in the $\mathrm{NO}_{\mathrm{x}}$ waiver section, for the consequence of denying the

132 Id. at 10,328. Similarly, in granting 1981-1982 waivers, the EPA found "marginal" proof of good faith with respect to some manufacturers but, questionably relying on language in International Harvester about the shifting of the burden of proof, found no proof that the manufacturers were in bad faith. 44 Fed. Reg. 53,376, 53,383 (1979).

154 Clean Air Act Amendments of 1977, Pub. L. No. 95-95, \& 201(c), 91 Stat. 752 (amending Clean Air Act $\$ 202(b)(5)(C)$ ) (current version at 42 U.S.C. $\$ 7521(b)(5)(C)$ (Supp. I 1977)).

155 Clean Air Act Amendments of 1970, Pub. L. No. 91-604, § 6(a), 84 Stat. 1691 (amending Clean Air Act $\S 202(b)(5)(C)$ ) (current version at 42 U.S.C. $\S 7521(b)(5)(C)$ (Supp. I 1977)).

1s Currie, Federal Air-Quality Standards and Their Implementation, 1976 AM. B. FounDATION RESEARCH J. 365, 368, 380, 389-90, 408.

137 See text and notes at notes 51-67 supra.

138 See text and notes at notes 124-125 supra.

135 See 43 Fed. Reg. 47,272, 47,274 (1978); 44 Fed. Reg. 53,376, 53,377 (1979). In the latter proceeding, the EPA found that the health consequences of waiving the standards as to certain models would be "insignificant." Id. 
waiver on health grounds in the latter case is only to hamper research, while in the former it may shut down the auto industry.

Of course this threat, like that in the standards themselves, is largely mythical; Congress can be expected to intervene if necessary. But the whole purpose of provision for administrative variances is to avoid the need for awkward and possibly uninformed congressional intervention. If there are to be waiver provisions, one would think they should be flexible enough to allow for waiver in all cases of unreasonable hardship.

f. Effect of Denial. One thread running throughout the preceding discussion is the assumption that if a carbon monoxide waiver is denied, the manufacturer who cannot meet the standard must shut down. This is a common assumption in assessing claims of hardship in variance cases. But a shutdown is not the inevitable result of a variance denial; the remedy in a subsequent enforcement proceeding may, as the practice of at least one state agency illustrates, be limited to money penalties if the statute provides for them, ${ }^{160}$ as section 205 does. ${ }^{161}$ By this procedure the enforcement agency can avoid either inflicting unreasonable hardship or rewarding bad faith.

Further, even when the manufacturer has done his best to comply, monetary liability may spur, as an outright waiver may retard, technological development. A 1977 amendment relating only to certain truck standards, considered below, ${ }^{162}$ embodies an idea that might profitably be extended to technology-forcing standards generally: in case of inability to comply, the manufacturer may continue production, but must pay a fee for the privilege. ${ }^{163}$ In theory, the same result might be achieved under present law with respect to automobiles by holding that the "public interest" does not require a waiver, but rather can best be served by imposing money penalties. I doubt, however, that this is in accord with the spirit of the public-interest provision; the House Committee said that a nonconformance-penalty provision "would change existing law which does not permit the introduction of nonconforming automobiles into the market."164

${ }^{160}$ See Currie, Enforcement Under the Illinois Pollution Law, 70 Nw. U.L. REv. 399, 42023 (1975).

16142 U.S.C. § 7524 (Supp. I 1977).

${ }^{162}$ See text and notes at notes 384-403 infra.

los § 206(g), 42 U.S.C. \& 7525(g) (Supp. I 1977).

II H.R. REP. No. 294, 95th Cong., 1st Sess. 18 (1977), reprinted in [1977] U.S. CoDE Cong. \& AD. News 1077, 1096.

The court in International Harvester isolated the potential inequity of relaxing standards 
3. Hearings. Section 202(b)(5)(C) requires a "public hearing" before action on an application to waive the carbon monoxide standard, without specifying hearing procedure. ${ }^{165}$ The interpretation of this requirement in International Harvester stands as an important starting point for construction of the many similarly phrased requirements scattered throughout the federal pollution laws.

a. The International Harvester Decision. First, the court held, a "trial type hearing" was not required:

[T] his provision for a "public hearing" contrasts significantly with other provisions that specifically require an adjudicatory hearing [citing the since-repealed section $110(f)(2)$ on postponement of implementation-plan requirements and section $206(b)(2)(B)$ on suspension of vehicle certification for violations, both requiring decisions "on the record"]. More importantly, the nonadjudicatory nature of the "public hearing" contemplated is underscored by the 60 day limit for a decision to be made. ${ }^{168}$

The absence of a record requirement was emphasized, the court added, by the statutory reference to "other information available" to the Administrator. ${ }^{167}$ Thus, the court concluded:

In context, the "public hearing" provision amounts to an assurance by Congress that the issues would not be disposed of merely on written comments, the minimum protection assured by the Administrative Procedure Act for rule-making, but would also comprehend oral submissions of a legislative nature. . . . Even assuming oral submission, in a situation where "general policy" is the focal question, a legislative-type hearing is appropriate. ${ }^{168}$

at the last minute to avoid the risk of shutdown:

The case is haunted by the irony that what seems to be Ford's technological lead may operate to its grievous detriment. . . . If in 1974, when certification of production vehicles begins, any one of the three major companies cannot meet the 1975 standards, it is a likelihood that standards will be set to permit the higher level of emission control achievable by the laggard. . . . [T] [he Government's action, in first imposing a standard not generally achievable and then relaxing it, is likely to be detrimental to the leader who has tooled up to meet a higher standard than will ultimately be required.

... [T]he high achievement in emission control results, under systems presently available, in lessened car performance . . . .

478 F.2d at $637-38$ (citations omitted). This problem too could be solved by imposing money penalties rather than shutdown as the standard remedy for noncompliance.

us 42 U.S.C. \& 7521(b)(5)(C) (Supp. I 1977).

its 478 F.2d at 629 .

${ }^{117}$ Id. at 630 n.48 (citing what is now 42 U.S.C. $\$ 7521$ (b)(5)(C)(iv) (Supp. I 1977)).

its 478 F.2d at 630 (citations omitted). 
On the other hand, more than the ordinary legislative hearing was required. In International Harvester itself "the general policy questions became interfused with relatively specific technical issues." ${ }^{168}$ Therefore, the court decided that while the EPA's practice of allowing submission of written questions to be put to witnesses orally by the Hearing Panel satisfied "basic fairness" under the circumstances, "a right of cross-examination, consistent with time limitations, might well extend to particular cases of need, on critical points where the general procedure proved inadequate to probe 'soft' and sensitive subjects and witnesses." 170 It was "contemplated," the court concluded, that "the remand proceeding will involve some opportunity for cross-examination," specifically "on a proffer that critical questions could not be satisfactorily pursued-by procedures previously in effect."171 Finally, "the parties should have opportunity on remand to address themselves to matters not previously put before them by EPA for comment, including material contained in the Technical Appendix filed by EPA in 1972 subsequent to its Decision."172

While this decision seems straightforward enough to permit reasonably simple administration, some particularly vexing questions remain: whether it was correct, whether it would be followed today, and whether it can be applied to other "public hearing" provisions.

b. Oral Participation. In determining what sort of proceeding was required by the statute in International Harvester, the place to begin is the Supreme Court's fundamental and unimpeachable, if less than comforting, declaration in United States $v$. Florida East Coast Railway, 173 that the meaning of the term "hearing" "will vary, depending on whether it is used in the context of a rulemaking-type proceeding or in the context of a proceeding devoted to the adjudication of particular disputed facts."174 In the absence of indications to the contrary, it seems reasonable to assume that Congress used the term to refer to the type of hearing commonly held in resolving similar matters. Thus, when the "hearing" is to determine whether sanctions should be imposed upon an individual for offending the law, as in the provision for revoking vehicle certifications distin-

\footnotetext{
189 Id.

170 Id. at 631.

17 Id. at 649 .

172 Id.

173410 U.S. 224 (1973).

"in Id. at 239.
} 
guished in International Harvester, ${ }^{175}$ it is normal to interpret an unelaborated "hearing" requirement as something resembling a judicial trial; ${ }^{176}$ when it is to set nationwide standards on a subject such as automotive safety, it is normal to find the same words satisfied by the kind of speech-making proceeding familiarly conducted by legislative committees. ${ }^{177}$

The issue is complicated by the Supreme Court's further and quite surprising holding in Florida East Coast that a "hearing" requirement respecting charges for the use of freight cars need fit neither the legislative nor the adjudicative model, but was satisfied by notice and written comments with no opportunity for oral presentation whatever. ${ }^{178}$ Although written procedure for general rulemaking is the norm under the Administrative Procedure Act (APA) ${ }^{179}$ when other statutes are silent, Professor Davis seems on sound ground in suggesting that it was not generally thought of before Florida East Coast as constituting a "hearing": "The new term 'oral hearing' is now necessary to express the meaning that 'hearing' once had. The word 'oral' in the phrase used to be redundant." 180

175 That provision is now codified at 42 U.S.C. $\$ 7525(6)(2)(B)$ (Supp. I 1977). See text at note 166 supra.

177 Cf. ICC v. Louisville \& N.R.R., 227 U.S. 88, 91-94 (1913) (individual railroad rates).

i77 See Norwegian Nitrogen Prods. Co. v. United States, 288 U.S. 294 (1933):

What is done by the Tariff Commission and the President in changing the tariff rates to conform to new conditions is in substance a delegation ... of the legislative process. . . . The inference is, therefore, a strong one that the kind of hearing assured by the statute to those affected by the change is a hearing of the same order as had been given by congressional committees when the legislative process was in the hands of Congress and no one else.

Id. at 305 (citations omitted). As to the nature of the typical congressional hearing:

[T] he hearing . . . is not similar to trial as conducted in a court. The proponents of a bill and the contestants make their statements for and against, bringing forward such confirmatory documents . . . as they believe to be important. . . . In none of these congressional hearings has the practice ever prevailed of permitting the advocates of a measure to cross-examine the opponents, or the opponents the advocates, or of compelling the committee itself to submit to an inquisition .....

Id. at 304. While the Court attempted to define the power of the Tariff Commission as simply advisory, id. at 317-19, the same reasoning applies to any case of general rulemaking, and the Court acknowledged that the President, in acting on the Commission's advice, had the power to make law, id. at 303.

178410 U.S. at $240-42$.

175 U.S.C. $\$ 553$ (1976).

$1801 \mathrm{~K}$. Davis, Administrative Law Treatise $\& 6.22$, at 556-57 (2d ed. 1978). That the APA twice uses the term "hearing" in ways suggesting that it embraces purely written procedure, as the Court in Florida East Coast emphasized, 410 U.S. at 240-41, proves only that the word is susceptible of such an interpretation, not that it is what Congress had in mind in the freight-car statute. 
The issue in International Harvester was whether the statute required more than a legislative hearing, not whether it allowed less, and the dictum that written procedure would not have sufficed is arguably contrary to Florida East Coast. The court gave no basis for distinguishing that decision, nor any reasons to support its statement that the "public hearing" requirement assured "oral submissions of a legislative nature." 181

One possible basis for the distinction is the nature of the proceeding. ${ }^{182}$ More fundamentally, however, the International Harvester dictum is representative of a tendency in the courts of appeals not to follow the lead of Florida East Coast in validating purely written proceedings when the statute requires not simply a "hearing" but a "public hearing." Similar to-International Harvester, but in an unquestionable context of general rulemaking, was the post-Florida East Coast statement of the First Circuit ${ }^{183}$ in construing the "public hearing" requirement of section $110(\mathrm{c})^{184} \mathrm{re}$ specting plans for implementing air-quality standards: "Public hearing' encompasses oral presentation and, thus, expands the minimum requirements for informal rule-making" beyond notice and comment. ${ }^{185}$

Absent Florida East Coast, I should have thought this position eminently correct. I should, however, have read that opinion as establishing the general principle that "hearing" without more in a general rulemaking context means notice and written comment. Perhaps the Supreme Court would regard the addition of the word "public" as a term of art indicating oral procedure, though on its face "public" participation may be written as well as oral. Since the EPA has to date allowed oral participation in proceedings concerning automotive-control suspensions, ${ }^{186}$ the question whether less is permissible may never arise. But given Florida East Coast, that cannot be taken for granted.

c. Decision on the Record. Probably of more practical significance is the question whether procedures going beyond the typical legislative hearing will be necessary in a waiver hearing. This question has two parts. First is whether a trial-type proceeding on the record is required, which would trigger the specific procedures of

181478 F. $2 d$ at 630 .

182 See text and notes at notes 189-205 infra.

${ }_{183}$ South Terminal Corp. v. EPA, 504 F.2d 646 (1st Cir. 1974).

is Now codified at 42 U.S.C. $\$ 7410$ (c) (Supp. I 1977).

18s 504 F.2d at 660 n.15.

18! See, for example, International Harvester, 478 F.2d at 624; 44 Fed. Reg. 53,376-77 (1979). 
sections 556 and 557 of the APA. ${ }^{187}$ The second, considered below, ${ }^{188}$ is whether additional specific procedures are required in a waiver proceeding if a trial-type proceeding on the record is not.

i. The Context. The court in International Harvester seemed to rely in part on the nature of the proceeding in holding that a decision on the record was not required, apparently classifying the matter before it as "rule-making." 189 In general rulemaking, as we have seen, the ordinary interpretation of "hearing" is a legislative one. Whether the International Harvester decision should have been considered general rulemaking, however, is open to question.

It is true that the Administrator at the end of the International Harvester waiver proceeding said he was prescribing new standards for all cars ("all 1975 light duty vehicles . . . [except in California, for which different standards were set] shall be subject to the following federal interim standards"); ${ }^{190}$ that his decision has been generally so interpreted; ${ }^{191}$ and that the setting of generally applicable auto-emission standards is the sort of thing that is commonly done after either legislative hearings or written procedure. The statutory waiver provision, however, provided for no such result, but rather said that "any manufacturer may file . . . an application requesting the suspension . . . of the effective date of any emission standard . . . with respect to such manufacturer." 192 If the Administrator decided to grant "such suspension," he was authorized to set interim standards for "such vehicles and engines," 193-those of the applying manufacturer. In fact, the Administrator reflected this distinction between general and individual applicability elsewhere in his opinion when he recited that a suspension had been granted "to the five applicants" (GM, Ford, Chrysler, AMC, and Harvester). ${ }^{194}$ To the extent that other passages in the order purported to suspend the standards as to other manufacturers, so far as I can see they did so completely without authority. In short, section 202(b)(5) was a garden-variety provision for granting individual

${ }^{187} 5$ U.S.C. $\$ \S 556,557$ (1976).

188 See text and notes at notes 219-227 infra.

1378 F.2d at 630 . See text at notes $168-172$ supra.

10038 Fed. Reg. 10,317, 10,319 (1975).

1" See, e.g., H.R. REp. No. 294, 95th Cong., 1st Sess. 232 (1977), reprinted in [1977] U.S. Code Cong. \& AD. News 1077, 1311: "[T] he 1975 requirements for hydrocarbons (HC) and carbon monoxide (CO) were pushed back [to] 1976."

132 Clean Air Act Amendments of 1970, Pub. L. No. 91-604, § 6(a), 84 Stat. 1691 (amending Clean Air Act $\S 202(\mathrm{~b})(5)(\mathrm{A})$ (current version at 42 U.S.C. $\S 7521(\mathrm{~b})(5)(\mathrm{A})$ (Supp. I 1977)).

ins Id.

is 38 Fed. Reg. 10,317, 10,317 (1975). 
manufacturers variances from otherwise applicable general requirements.

The APA defines a "rule" broadly: "an agency statement of general or particular applicability and future effect designed to implement, interpret, or prescribe law or policy."195 Standing alone, this definition literally embraces variances, as it does obviously adjudicative ${ }^{196}$ cease-and-desist orders. But Florida East Coast strongly suggests that administrative action within the APA definition of rulemaking may nevertheless be of such a nature as to require that a statutory "hearing" be read as a trial. Thus, although the Attorney General's Manual on the Administrative Procedure Act tells us, as the definition suggests, that "the prescription of future rates for a single named utility by the Federal Power Commission, and similar agency actions, although applicable only to named persons, constitute rule making," 197 the Supreme Court long ago construed the term "full hearing" to require judicial-type trials for determining the future rates chargeable by individual railroads ${ }^{198}$ or at individual stockyards. ${ }^{199}$ In Florida East Coast, which concerned freight-car use charges applicable to all railroads, the individual-rate cases were distinguished as "quasi-judicial." 200 Thus, if the International Harvester proceedings were "rulemaking" at all, they were of a type-"quasi-judicial"-in which the context indicated the "hearing" prescribed should be more than legislative.

Moreover, it seems clear that, despite its terms, the broad APA rulemaking definition cannot be applied to variances at all. Variance proceedings, like those leading to cease-and-desist orders, are typically regarded as adjudicative, and trial-type procedures are usually provided for them. ${ }^{201}$ Indeed, a request for suspension of the statutory vehicle standards seems to be one for a "statutory exemption," which under the APA is "licensing," 202 and licensing in turn is deemed even by that statute to be adjudication-despite the broad rulemaking definition. ${ }^{203}$ In the analogous context of a permit

1955 U.S.C. $\$ 551(4)(1976)$.

i' See U.S. Dep't of Justice, Atrorney General's Manual on the Administrative Procedure Act 15 (1947) [hereinafter cited as Attorney General's Manual].

197 Id. at 13.

${ }^{183}$ ICC v. Louisville \& N.R.R., 227 U.S. 88, 91-94 (1913).

199 Morgan v. United States (I), 298 U.S. 468, 479-81 (1936).

200410 U.S. at 242. The Morgan opinion referred to by Florida East Coast was a later episode in the same proceeding, 304 U.S. 1 (1938), and the Court distinguished it on the further ground (not applicable to Morgan $h$ of inadequate notice.

${ }^{201}$ E.g., Ile. Rev. Stat. ch. 1111/2, §§ 1037, 1032-33 (1977).

${ }^{202} 5$ U.S.C. $\$ 551(8)-(9)(1976)$.

${ }^{203}$ Id. $\S 551(6)-(7)$. See Scalia, Vermont Yankee: The APA, the D.C. Circuit, and the 
to discharge heated water without meeting ordinarily applicable standards, the First Circuit quoted from the Attorney General's Manual to hold that a "public hearing" requirement implied a trial on the record subject to the formal-hearing rules of the APA: "It is believed that with respect to adjudication the specific statutory requirement of a hearing, without anything more, carries with it the further requirement of decision on the basis of the evidence adduced at the hearing.' "'204 Similarly, the nature of the proceeding to suspend the vehicle standards argues that the "public hearing" required by the statute is a full-scale APA trial. ${ }^{205}$

ii. The Statute. The International Harvester court's principal reliance, however, was placed not on what it thought to be a "rulemaking" context but on independent evidence drawn from the statute: the contrast with provisions explicitly requiring "record" (trial-type) proceedings for other determinations, the demanding requirement of a decision in sixty days, which indicates "concern with 'avoidance of . . . time-consuming procedures,' " and the reference to "other information available," which sounds as if it may be outside the record. ${ }^{206}$ That these considerations carry some

Supreme Court, 1978 SuP. CT. Rev. 345, 351 \& n.33. In United States Steel Corp. v. Train, 556 F.2d 822, 833-34 (7th Cir. 1977), the court held APA formal-trial procedures applicable to the grant of a permit to discharge water pollutants under 42 U.S.C. section 1342 although the statute required only a "public hearing." 556 F.2d at 833-34. Indeed, the court carried the licensing argument a step further, concluding that because under the statute a permit was "an application . . . for a license required by law," the licensing provision of the APA, 5 U.S.C. $\$ 558(c)$ (1976), required the EPA to conduct proceedings "in accordance with sections 556 and 557" of that statute, which prescribe a quasi-judicial proceeding. $556 \mathrm{~F} .2 \mathrm{~d}$ at 833 34. On this the court went too far, for section 558 appears directed toward expedition rather than the nature of the proceeding: "[T] leges of all the interested parties or adversely affected persons and within a reasonable time, shall set and complete proceedings required to be conducted in accordance with sections 556 and 557 of this title or other proceedings required by law and shall make its decision." 5 U.S.C. $\$ 558$ (c) (1976) (emphasis added).

201 Seacoast Anti-Pollution League v. Costle, 572 F.2d 872, 877 (1st Cir. 1978) (quoting Attorney General's Manual, supra note 196, at 42-43). Accord, Marathon Oil Co. v. EPA, 564 F.2d 1253 (9th Cir. 1977); United States Steel Corp. v. Train, 556 F.2d 822 (7th Cir. 1977).

${ }_{20}$ This remains true under the 1977 amendments; though the conclusive words "with respect to such manufacturer," Clean Air Act Amendments of 1970, Pub. L. No. 91-604, $\$$ 6(a), 84 Stat. 1691 (amending Clean Air Act $\S 202(b)(5)$ ) (current version at 42 U.S.C. $\$$ 7521(b)(5) (Supp. I 1977)), are replaced by references to "any model" and "such model," 42 U.S.C. § 7521(b)(5)(A) (Supp. I 1977), the implication is that each manufacturer is to seek relief for his own models, and Senator Muskie so explained it. See 123 CoNG. REc. 13,703 (daily ed. Aug. 4, 1977) ("not a general waiver for all manufacturers, nor . . . for all models ... produced by a single manufacturer"). The EPA, quoting this passage in its guidelines for CO waivers, agrees. 43 Fed. Reg. 47,272, 47,273 (1978). Indeed, in passing on applications under the 1977 provisions it explicitly granted suspensions for some models and denied them for others. 44 Fed. Reg. 53,376, 53,408 (1979) (amending 40 C.F.R. § 86.081-8(ii)).

${ }^{206} 478$ F.2d at $629-30$. 
weight is undeniable, though the assumption of consistent usage in a statute of this complexity seems strained; I would be unhappy if every reference to a "public hearing" in the Clean Air Act were held to mean a legislative one regardless of context simply because other sections use the magic word "record." In the absence of constitutional overtones, I would, despite the quasi-adjudicatory context, accept the court's conclusion that in this instance no trial was intended.

iii. Due Process. But there are constitutional overtones. The statute appears to give the manufacturer a right to a suspension or waiver whenever the prescribed criteria are met. ${ }^{207}$ Thus, like the applicant for bar admission ${ }^{208}$ and the welfare recipient, ${ }^{209}$ the manufacturer claims an "entitlement" that seems to constitute "property" or "liberty" within the protection of the due process clause. It follows that, like them, he may be entitled by due process to a full adjudicative hearing on disputed matters of fact particular to his case..$^{210}$

The requirements of due process vary according to a balance of competing interests, and for some interests within the due process clause little or no procedure is required. ${ }^{211}$ I think, however, that the stakes in a typical variance case, and in an auto-emission case in particular, are great enough that-as in bar admission, welfare termination, and rate-setting for individual firms-disputed adjudicative facts must be resolved by something approaching judicial pro-

${ }^{207}$ Although at the time of International Harvester it said the Administrator "shall grant such suspension only if" the conditions are met, Clean Air Act Amendments of 1970, Pub. L. No. 91-604, § 6(a), 84 Stat. 1692 (amending Clean Air Act $\S 202(b)(5)(D)$ ), and now it says he "may" grant it, $\$ 202(\mathrm{~b})(5)(c), 42$ U.S.C. $\$ 7521$ (b)(5)(C) (Supp. I 1977), all parties in International Harvester seem to have assumed, and I think rightly, that Congress meant for a suspension to be granted if the prescribed showing was made. See S. REP. No. 1196, 91st Cong., 2d Sess. 28 (1970):

The Court in reviewing the Secretary's decision can affirm or reverse only after independently finding that a suspension is essential to the public interest and general welfare ... . t that all good faith efforts have been made . . . ; and that . . technology . . . [has] not been available. . . . The industry could challenge [the Secretary's] ... decision not to extend ... the deadline ....

The Senate bill provided that "[t]he Secretary shall grant such suspension only if" he found the conditions satisfied. The Conference Report did not suggest that the final choice of words was intended to make any substantial change. See H.R. REP. No. 1783, 91st Cong., 2d Sess. (1970), reprinted in [1970] U.S. Code CoNG. \& AD. NEws 5374.

2as Willner v. Committee on Character \& Fitness, 373 U.S. 96 (1963).

200 Goldberg v. Kelly, 397 U.S. 254 (1970).

210 Id. at 266-70.

21I E.g., Ingraham v. Wright, 430 U.S. 651 (1977) (corporal punishment of students); Goss v. Lopez, 419 U.S. 565 (1975) (school suspension). 
cedure, including a decision on the record..$^{212}$ If this is true, then under the principles of Wong Yang Sung v. McGrath ${ }^{213}$ the formalhearing requirements of sections 556 and 557 of the APA probably should be held to apply.

Although the International Harvester procedure was objected to on due process grounds, ${ }^{214}$ the court did not discuss the question of a quasi-judicial trial as a due process matter, presumably because of the court's view that it was dealing with general rulemaking, for which the Constitution does not require a full trial. ${ }^{215}$ Moreover, the Administrator had denied the suspension for failure to establish that "effective control technology" was "not available," a "legislative" fact question if there ever was one, which undoubtedly could have been established without trial procedures even in a judicial proceeding. ${ }^{216}$ The same may be said of the 1977 requirement that the suspension not be precluded by considerations of "public health," and of many components of the "public interest" requirement, while the "study and investigations" of the National Academy of Sciences can probably best be established by submission of official reports. The "good faith" criterion, however, is quite another matter. While its phrasing is ambiguous, the Administrator seems correct in having viewed it as referring to the good faith of the individual applicant, which he determined with respect to Chrysler on the basis of facts specific to Chrysler alone. ${ }^{217} \mathrm{I}$ do not see how one can fairly escape the conclusion that when the good faith of an individual applicant is disputed in a suspension proceeding, a trial on that issue is required by due process. ${ }^{218}$

d. Cross-examination and Comment. The next question is whether, assuming, as International Harvester held, that a full trial is not required, specific additional procedures such as crossexamination or the opportunity for comment on EPA documents are necessary. So far as the statute itself is concerned, I see no basis to answer this question differently from the question whether a full

${ }_{212}$ Cf. Ohio Bell Tel. Co. v. Public Utils. Comm'n, 301 U.S. 292 (1937) (record hearing required before utility must surrender excess earnings); West Ohio Gas Co. v. Public Utils. Comm'n, 294 U.S. 63 (1935) (same for rate-fixing by a utility).

213339 U.S. 33 (1950).

214478 F.2d at 629.

${ }_{215}$ Bi-Metallic Inv. Co. v. State Bd. of Equalization, 239 U.S. 441 (1915).

216 See K. Davis, Administrative Law Text, $\S 7.03$, at 160 (3d ed. 1972); Karst, Legislative Facts in Constitutional Litigation, 1960 Sup. Cr. Rev. 75.

217 See text at notes 150-153 supra.

218 The EPA's guidelines for CO waivers under the 1977 amendments indicate that the Agency will base its decision on the "public record" but do not guarantee a quasi-judicial trial. 43 Fed. Reg. 47,272, 47,273 (1978). 
trial is required: in general rulemaking, which the court thought this was, a "hearing" did not at the time typically include either of these rights; in the adjudicatory-variance proceeding actually prescribed, it did; the short time period, the contrast with "record" provisions, and the allowance of "other information" argue that Congress meant a purely legislative hearing. Indeed, the court did not seriously attempt to derive support for its cross-examination and comment requirements from the statute, though it did once quote in this discussion the statutory term "hearing"; it spoke instead essentially of "basic fairness." 119

Since due process was argued, ${ }^{220}$ perhaps "basic fairness" was intended as a paraphrase of due process. If so, the conclusion is surprising in light of the court's perception that it was dealing with general rulemaking, for the general view has been that in such a proceeding due process imposes no procedural constraints at all, ${ }^{221}$ and the Florida East Coast holding that notice-and-comment procedure suffices in such cases ${ }^{222}$ bodes poorly for any constitutional argument for cross-examination or comment there. On my assumption that the matter was essentially an adjudicatory variance proceeding, however, the due process case is a better one. That the issue of technological availability was itself a "legislative" one does not necessarily mean, in this context, that due process imposes no constraints on how it is resolved. Although it need not be made the subject of an evidentiary trial, there is Supreme Court authority suggesting that due process requires the opportunity to rebut the taking of official notice of a similarly legislative fact. ${ }^{223}$ Crossexamination on specific issues of legislative fact that otherwise "could not be adequately ventilated," as International Harvester required, ${ }^{224}$ would be a bold but not a shocking step beyond in the changing climate of due process.

An alternative reading of the court's reliance on "basic fairness" is that, understandably unwilling to base its decision on the

${ }^{219} 478$ F.2d at 631 . See also id. at 630 (" 'basic considerations of fairness" "); id. at 649 ("the interest of justice"). Also mentioned, $i d$., was 28 U.S.C. section 2106 , which irrelevantly spells out broad powers of an appellate court respecting review of an order of "a court," not of an administrative agency.

${ }^{220}$ See 478 F.2d at 629 .

221 Bi-Metallic Inv. Co. v. State Bd. of Equalization, 239 U.S. 441 (1915). See Williams, "Hybrid Rulemaking" Under the Administrative Procedure Act: A Legal and Empirical Analysis, 42 U. Chi. L. Rev. 401 (1975).

222 See text at note 178 supra.

${ }^{223}$ Ohio Bell Tel. Co. v. Public Utils. Comm'n, 301 U.S. 292 (1937) (agency took notice of trends in market value of property).

224478 F.2d at 631. 
Constitution in light of the precedents applicable to general rulemaking, the court chose to enunciate common-law requirements of cross-examination and reply. Procedural requirements of similarly ambiguous origin have proliferated in recent opinions of the District of Columbia Circuit. ${ }^{225}$ Insofar as such requirements are based upon a theory that the courts may impose upon agencies procedures required by neither Constitution nor statute, the Supreme Court attempted in no uncertain terms to put an end to them in its opinion last year in Vermont Yankee Power Corp. v. Natural Resources Defense Council, Inc. ${ }^{228}$ " [N] othing . . . permitted the court to review and overturn the rulemaking proceeding on the basis of the procedural devices employed (or not employed) by the Commission as long as the Commission employed at least the statutory minima ?

It thus seems quite unlikely that, if the International Harvester court's perception of section 202(b)(5) waiver proceedings as general rulemaking prevails, its requirement of cross-examination will be adhered to. In any event, as Professor Williams has reported, this fiercely sought right was not exercised on remand in International Harvester itself.

e. $N O_{x}$ Waivers. The remaining question is the extent to which the International Harvester conclusions, or what is left of them, will be applicable to the various new provisions for waiver of nitrogen oxide standards. ${ }^{228}$ The diesel- and innovation-waiver paragraphs explicitly require "public hearing," and the context is the same as that in International Harvester: "[a]ny manufacturer" may petition for a waiver "for any class . . . of . . . vehicles . . . manufactured by such manufacturer."229 Missing, though, are two of the three textual props relied on for rejecting a full trial in

${ }_{225}$ E.g., Home Box Office, Inc. v. FCC, 567 F.2d 9 (D.C. Cir. 1977); Mobil Oil Corp. v. FPC, 483 F.2d 1238 (D.C. Cir. 1973); Kennecott Copper Corp. v. EPA, 462 F.2d 846 (D.C. Cir. 1972). See generally Scalia, supra note 203.

226435 U.S. 519,548 (1978).

227 Williams, supra note 221 , at 434 . The Administrator's opinion in support of his partial suspension of the 1981-1982 CO standards indicates only that a "public hearing" was held and "testimony" received; it does not say whether additional procedural rights such as crossexamination were afforded. 44 Fed. Reg. 53,376 (1979).

The requirement of opportunity to comment on materials on which the EPA relied, on the other hand, has been further developed in a subsequent opinion of the District of Columbia Circuit that may survive Vermont Yankee. Portland Cement Ass'n v. Ruckelshaus, 486 F.2d 375 (D.C. Cir. 1973). This requirement will be discussed in a subsequent article.

$z 2 \times$ 202(b)(1)(B), (6)(A), 42 U.S.C. $\$ 7521(\mathrm{~b})(1)(B),(6)(A)$ (Supp. I 1977). See text and notes at notes $116-125$ supra.

$223 \S 202(\mathrm{~b})(6)(\mathrm{A})-(\mathrm{B}), 42$ U.S.C. $\S 7521(\mathrm{~b})(6)(\mathrm{A})-(\mathrm{B})$ (Supp. I 1977$).$ 
International Harvester: the 60-day time for decision and the reference to "other information." Yet the waiver provisions are so similar in other respects that it seems quite unlikely Congress had any different procedure in mind, and the legislative nature of most of the facts relevant to these $\mathrm{NO}_{\mathrm{x}}$ waivers reinforces the conclusion that International Harvester, as arguably modified by Vermont Yankee, will be held to govern their procedure.

The $\mathrm{NO}_{\mathrm{X}}$ waiver for small manufacturers is another story. ${ }^{230}$ Confusingly, it appears not with the other waiver provisions but in the body of the paragraph prescribing standards; it speaks not of "waiver" but directs the Administrator to "prescribe standards in lieu of those" in the statute; it makes no mention of a "hearing" or other procedure. These features alone would suggest an exercise in general rulemaking governed by the notice-and-comment procedures of the APA. Like the other waivers, however, these standards are to apply to "any manufacturer" as to whom the Administrator "determines" certain facts. Moreover, those facts are peculiar to the individual manufacturer: his dependency upon the developmental abilities of others and (what may be the same thing) his lack of resources to develop technology on his own. ${ }^{231}$ Thus, despite the language of "standards," the essence of this provision seems to be to give individual manufacturers an entitlement to relief upon a showing of adjudicative facts. In such circumstances, as I have argued above, due process requires opportunity for a trial..$^{232}$

\section{Other Vehtcles}

Congress in 1977 was dissatisfied with the emission standards for trucks and buses set by the EPA under the general authority of section 202(a). The House Report noted:

$[P]$ rogress in regulating new motor vehicle emissions from vehicles other than the passenger car has lagged. . . . 1977 Federal standards require heavy-duty gasoline-powered engines to achieve only a 15 per cent reduction in $\mathrm{HC}$ plus $\mathrm{NO}_{\dot{\mathrm{x}}}$ emissions, and only a 57 per cent reduction in $\mathrm{CO}$ emissions, from uncontrolled levels . . . and no reduction of $\mathrm{HC}, \mathrm{NO}_{\mathrm{X}}$, or $\mathrm{CO}$ from uncontrolled diesel-powered engines. ${ }^{233}$

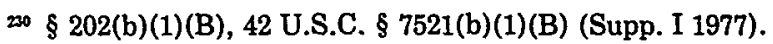

${ }^{231} I d$.

232 The Administrator, in passing on American Motors's request under this provision, invited written public comment. None was received, and the application was granted on the basis of AMC's submissions. See 44 Fed. Reg. 47,880 (1979).

${ }^{233}$ H.R. REP. No. 294, 95th Cong., 1st Sess. 271-72 (1977), reprinted in [1977] U.S. CoDE 
And the Report, quoting from a Library of Congress study, observed that under these standards

a heavy duty truck will emit as much nitrogen oxides as nine automobiles, as much $\mathrm{HC}$ as 18 automobiles, and as much $\mathrm{CO}$ as 45 automobiles. . . . At some time between 1980 and 1989, the emissions from heavy-duty vehicles will be more than half of all transportation emissions, unless control regulations are revised. ${ }^{234}$

The consequence of this concern was a new paragraph (3) of section 202(a), ${ }^{235}$ the central thrust of which is to prescribe the future content of $\mathrm{HC}, \mathrm{CO}$, and $\mathrm{NO}_{\mathrm{X}}$ regulations for new heavy-duty vehicles.

\section{A. Ultimate and Interim Heavy-Duty Standards}

The basic requirement, in section 202(a)(3)(A)(ii), is that carbon monoxide and hydrocarbon emissions be reduced by "at least 90 per cent" from unregulated levels by the 1983 model year and those of nitrogen oxides by "at least 75 per cent" by $1985 .{ }^{236}$ These are the same percentage reductions as those ultimately required for automobiles under section $202(\mathrm{~b}),{ }^{237}$ thus satisfying an immediate sense of equity. The House and Senate Reports make no attempt, as they did with automobile standards in $1970,{ }^{238}$ to correlate these percentages with ambient air quality; nor, the House Report emphasizes, did the Committee "conclude that they were certainly technologically feasible." 238 They were justified as "reasonable target levels" toward which "manufacturers [could] aim

Cong. \& AD. NEws 1077, 1350-51. The 1977 federal standards are set out in 40 C.F.R. $\$ 86.077-$ 10, -11 (1978).

234 H.R. REP. No. 294, 95th Cong., 1st Sess. 272 (1977) (quoting Library of Congress, Air Pollution: Uncontrolled Mobile Sources 2 (Issue Brief No. IB 74033 1975)), reprinted in [1977] U.S. Code CoNG. \& AD. News at 1351.

iss 42 U.S.C. \& 7521(a)(3) (Supp. I 1977).

${ }^{236}$ Id. $\$ 7521$ (a)(3)(A)(ii)(I)-(II). The "baseline model year" against which the reductions are to be judged is that "immediately preceding the model year in which Federal standards applicable to such vehicle or engine . . . first applied with respect to such pollutant." Id. § $7521(a)(3)(A)(v)$. Regulations to implement the 1983 heavy-duty HC and CO standards were proposed at 44 Fed. Reg. 9464 (1979).

${ }^{237}$ Except that the starting points for automotive reductions were 1970 levels of $\mathrm{HC}$ and $\mathrm{CO}$, which already represented some degree of control. See text and notes at notes $36,51-53$ supra.

238 See text and notes at notes 39-40 supra.

${ }^{23}$ H.R. ReP. No. 294, 95th Cong., 1st Sess. 274 (1977), reprinted in [1977] U.S. CodE Cong. \& AD. News 1077, 1353. 
research and development efforts," ${ }^{240}$ on the basis of laboratory results that were viewed as promising. ${ }^{241}$

In the interim, section 202(a)(3)(A)(i) directs the Administrator to set standards for "model years 1979 through 1982" that "reflect the greatest degree of emission reduction achievable through the application of technology which the Administrator determines will be available . . . , giving appropriate consideration to the cost of applying such technology within the period of time available to manufacturers and to noise, energy, and safety factors." ${ }^{2+12}$ With minor variations, this is the same formula previously applied to performance standards for new stationary sources under section $111,{ }^{243}$ which I shall discuss in detail in another article. Suffice it to say that the language clearly confirms the House Committee's intention, in accord with the International Harvester decision, to allow "reasonable projections about the future availability of technology"; 244 that, while the heavy-duty vehicle provision refers explicitly to "noise, energy, and safety" and section 111 to "health and environmental impact and energy requirements," the general injunction to consider "cost" in both instances is broad enough to include them all and should lead to interpreting the enumerated considerations as exemplary, not exclusive; $;^{245}$ and that there seems no reason to distinguish between the "degree of emission reduction" from "the best system" in section 111 and the "greatest degree of emission reduction . . available" in section 202(a)(3)(A).

It might be thought that the best-technology standard for interim truck emissions adds little, since the Administrator already had, and had exercised, discretionary authority under sections 202(a)(1) and (2) to set truck standards to protect health and welfare, "giving appropriate consideration to the cost of compliance" in the prescribed time. But it seems fair to say, as Justice Frankfurter once wrote in another setting, that in the new legislation "Congress expressed a mood" 248 that ought not to be lost upon ad-

$210 \mathrm{Id}$.

${ }^{241}$ Id. at 274 n.14, reprinted in [1977] U.S. CoDE CoNG. \& AD. NEwS at 1353 n.14.

${ }_{242}^{42}$ U.S.C. \& 7521(a)(3)(A)(i) (Supp. I 1977).

${ }^{213}$ Id. $\S 7411$.

24 H.R. REP. No. 294, 95th Cong., 1st Sess. 273 (1977), reprinted in [1977] U.S. CoDE Cong. \& AD. News 1077, 1352. See also id. at 273 n.12, reprinted in [1977] U.S. Code Cong. \& AD. NEws at 1352 n.12.

${ }^{215}$ Cf. Portland Cement Ass'n v. Ruckelshaus, 486 F.2d 375, 385 (D.C. Cir. 1973) (references to "the cost of achieving reduction" require the Administrator to "take into account environmental effects of a proposed standard").

24 Universal Camera Corp. v. NLRB, 340 U.S. 474, 487 (1951). 
ministrators and reviewing courts. While the identical words "appropriate consideration to the cost" appear in both the original provision (section 202(a)(2)) and the new one (section $202(a)(3)(A)(i))$, the context is no longer blandly neutral as to how the balance shall be struck. Congress was plainly convinced that standards set under the prior authority should be tightened, and the language it chose to express that conviction, modified by the new and compelling phrase "greatest . . . reduction achievable," had a history of judicial construction indicating that costs must be wellnigh prohibitive to be decisive. ${ }^{247}$

A minor matter that must be of some embarrassment to those who drafted the final statutory language is the evidently accidental omission of any provision concerning the content of nitrogen oxide standards for 1983-1984. The House bill had provided for besttechnology standards for all pollutants, including $\mathrm{NO}_{\mathrm{X}}$, through 1984 , with prescribed percentage reductions in $1985 .{ }^{248}$ In accelerating the date for $90 \% \mathrm{HC}$ and CO reduction to 1983, the Conference Committee reset the technology-standard date accordingly for all three pollutants at $1982^{249}$ without noticing that it had left the $75 \%$ $\mathrm{NO}_{\mathrm{x}}$ date at 1985. Authority to set 1983-1984 $\mathrm{NO}_{\mathrm{x}}$ standards must therefore be found in section 202(a)(1), and section 202(a)(3)(A) makes its exercise mandatory; in setting them the Administrator will doubtless take the best-technology standard for 1979-1982 as his guide for applying the cost criterion of section 202(a)(1).

\section{B. Revisions}

Aware that the technology required for the 1983 and 1985 reductions might not be forthcoming, Congress provided ample leeway for administrative adjustment to avoid undue hardship, in sensible contrast to the narrow automotive relief provisions. Sections 202(a)(3)(B) and (C) ${ }^{250}$ authorize revision of the final percentagereduction requirements upon a finding "that compliance . . . cannot be achieved by technology . . . reasonably expected to be available ... . without increasing cost or decreasing fuel economy to an excessive and unreasonable degree."251

This language is a fair paraphrase of the traditional variance

217 See, e.g., Portland Cement Ass'n v. Ruckelshaus, 486 F.2d 375 (D.C. Cir. 1973).

218 See H.R. ReP. No. 294, 95th Cong., 1st Sess. 407 (1977).

29 H.R. REP. No. 564, 95th Cong., Ist Sess. 163-64 (1977), reprinted in [1977] U.S. CoDE Cong. \& Ad. News 1502, 1543-45.

${ }^{250} 42$ U.S.C. $\$ 7521(a)(3)(B) .(C)$ (Supp. I 1977).

251 Id. $\$ 7521(\mathrm{a})(3)(\mathrm{C})(\mathrm{i})$. 
standard of unreasonable hardship, imposing a heavy burden of proof on industry while providing the necessary flexibility that obviates the need for awkward congressional intervention. The provision differs from the corresponding automobile provision in certain key ways: it applies to all pollutants for which statutory emission levels are prescribed; it allows repeated revisions at three-year intervals for as long as they may be necessary; by its reference to "excessive and unreasonable" costs it allows the hardship to be weighed against the benefits of compliance; it explicitly provides for revision by "regulations" rather than on application of individual manufacturers; and the criteria for revision include none (such as good faith) applicable to particular manufacturers. This last feature should suffice to avoid the arguments over procedure that have so confused litigation under the automobile provision; the required "public hearing," which is expressly subjected to the lengthy additional requirements of section $307(\mathrm{~d}),{ }^{252}$ should be held to be a legislative one. ${ }^{253}$

The refusal to focus upon individual circumstances, however, makes the revision tool a crude one. If there are differences between manufacturers in ability to comply or in good faith, the producers must apparently all sink or swim together. Indeed, good faith may not be relevant at all since the statute authorizes a revision if the technology, for whatever reason, is not "reasonably expected to be available." Arguably, good faith might enter in determining what is "reasonably" expected, but the more likely reading concerns the Administrator's confidence in the prediction that the technology will be available. It is more promising to view the provision that the Administrator "may" revise the standards as giving him some latitude to impose conditions beyond those listed in the statute, as the legislative history makes clear with respect to another similar provision. ${ }^{254}$

There are two additional conditions on revisions under sections $202(a)(3)(B)$ and (C). The first is that "the National Academy of Sciences has not . . . issued a report substantially contrary to the findings of the Administrator" with respect to technology. ${ }^{255}$ This time there is no question about it; the NAS is given a veto. $i$ find

${ }^{252} \mathrm{Id} . \S 7607(\mathrm{~d})(\mathrm{I})(\mathrm{J})$

${ }^{253}$ See text and notes at notes 173-186 supra.

254 See H.R. REP. No. 294, 95th Cong., 1st Sess. 67 (1977), reprinted in [1977] U.S. CodE CoNG. \& AD. NEws 1077, 1145 (commenting on the provision for delayed-compliance orders respecting implementation plans in what became 42 U.S.C. $\S 7413$ (d) (Supp. I 1977)).

${ }^{255} 42$ U.S.C. $\$ 7521$ (a)(3)(C)(ii) (Supp. I 1977). 
this delegation of unreviewable legislative authority to a quasipublic organization quite disturbing, even if under the more recent cases it is not unconstitutional. ${ }^{256}$

Second, while in revising a standard the Administrator is generally to follow the 1979-1982 formula of maximum reduction expected to be technologically feasible, ${ }^{257}$ the revised standard must in all circumstances "require a reduction of emissions from any standard which applies in the previous model year." 258 The motivation is obvious, but the requirement is hardly compatible with the general criterion allowing relaxation on the basis of available technology. If technology has not advanced since the preceding year, one cannot tighten a technological standard without requiring the use of technology that is not reasonably available.

A further opportunity for revision of the percentage-reduction standards, again by "regulations" after opportunity for "public hearing" subject to the procedural requirements of section $307(\mathrm{~d}),{ }^{259}$ is provided by section 202(a)(3)(E), on the basis of a required study of "the effects of each air pollutant emitted from heavy-duty vehicles . . . and from other sources of mobile source related pollutants on the public health and welfare" 260 and of "such other information as is available." ${ }^{261}$ No criteria whatever are provided to guide the determination under this provision. Since its exercise is plainly discretionary, it is not clear that it adds anything to the power already given to adopt more stringent standards under either section 202(a)(1), ${ }^{262}$ which allows the Administrator to set truck standards to protect the public health, or section $202(\mathrm{a})(3)(\mathrm{A})$, which directs the Administrator to achieve the "greatest degree of emission reduction . . . available." ${ }_{263}$ The section is necessary, however, to permit relaxation of the percentage standards on grounds other than the unavailability of technology, provided for in section 202(a)(3)(B). Yet there is a clear danger that the unconfined authority given by subparagraph $(\mathrm{E})$ may be so exercised as to undercut the evident

2ss Compare Carter v. Carter Coal Co., 298 U.S. 238, 311 (1936) with United States v. Rock Royal Coop., Inc., 307 U.S. 533, 574-76 (1939).

$257 \S 202(\mathrm{a})(3)(\mathrm{A})(\mathrm{i}), 42$ U.S.C. $\$ 7521$ (a)(3)(A)(i) (Supp. I 1977). The wording of the two provisions differs slightly; while the differences create a risk of divergent interpretation, comparison fails to suggest any significant discrepancies.

${ }^{2 s s}$ Id. $\S 7521(\mathrm{a})(3)(\mathrm{B})$.

2st Id. $\S 7607(\mathrm{~d})(\mathrm{i})(\mathrm{J})$.

${ }^{260} \mathrm{Id}$. $87521(\mathrm{a})(3)(\mathrm{E})(\mathrm{i})$.

201 Id. $\S 7521(\mathrm{a})(3)(\mathrm{E})(\mathrm{ii})$

${ }^{262}$ Id. § 7521(a)(1). See H.R. REP. No. 294, 95th Cong., 1st Sess. 273 n.13 (1977), reprinted in [1977] U.S. CoDE CoNG. \& AD. NEws 1077, 1352 n.13.

${ }^{265} 42$ U.S.C. \$ 7521(a)(3)(A)(i) (Supp. I 1977). 
attempt in subparagraph (B) to circumscribe narrowly the power to relax the standards. To reconcile the two, subparagraph (B) should be held the exclusive means of relaxation on grounds of technology or cost, while subparagraph (E) should be limited to revisions based upon the specifically mentioned consideration of effects of the pollutants on health and welfare. This reading accords with the House Report's statement that under this provision "the 1985 [and now 1983] targets could be revised to be more lenient or less lenient, as needed to protect health and welfare." 264

In addition to these provisions for formal revision of the standards, the 1977 amendments added an innovative provision for "nonconformance penalties," permitting under certain conditions the certification and sale of heavy-duty vehicles not meeting prescribed emission standards. The nonconformance penalty is discussed below in connection with enforcement of the standards. ${ }^{265}$

\section{Particulate Standards}

Section 202(a)(3)(A)(iii) directs the Administrator to "prescribe regulations . . . applicable to emissions of particulate matter from classes or categories of vehicles manufactured during and after model year 1981 (or during any earlier model year, if practicable)." ${ }^{206}$ The criterion for these standards is best technology, expressed in the same words as the 1979-1982 heavy-duty HC, $\mathrm{CO}$, and $\mathrm{NO}_{\mathrm{x}}$ standards, with the additional and probably redundant requirement that they "take effect as expeditiously as practicable taking into account the period necessary for compliance." 267 The Senate Committee had contemplated that ultimate particulate standards would be set on the basis of "the extent to which particulates are likely to cause or contribute to air pollution endangering public health or welfare," ${ }_{268}$ but the Conference Committee was unwilling to go so far. ${ }^{269}$

The interesting feature of this otherwise straightforward requirement is that on its face it appears to apply, unlike all the other paragraphs of section 202(a)(3), to all vehicles, not just to heavy-

261 H.R. REP. No. 294, 95th Cong., 1st Sess. 277 (1977), reprinted in [1977] U.S. CoDE Cong. \& AD. News at 1356.

${ }^{265}$ See text and notes at notes $384-403$ infra.

${ }^{265} 42$ U.S.C. $\$ 7521(a)(3)(A)(i i i)$ (Supp. I 1977).

${ }^{267}$ Id.

${ }^{268}$ S. REP. No. 127, 95th Cong., 1st Sess. 67 (1977).

${ }^{269}$ H.R. Rep. No. 564, 95th Cong., 1st Sess. 163 (1977), reprinted in [1977] U.S. CodE Cong. \& AD. News 1502, 1543-44. 
duty ones. The EPA so interprets it, relying unnecessarily on section 202(a)(3)(A)(iii) as authority for its new particulate standards for light-duty vehicles and light trucks; for reasons given earlier in this article, I think the Agency is mistaken. ${ }^{270}$

\section{Light-Duty Trucks and Recreational Vehicles}

With the possible exception of the particulate provision, the requirements of section 202(a)(3) apply only to "heavy-duty vehicles or engines" and, as discussed below, ${ }^{271}$ to motorcycles. Section 202(b)(3)(C), also added in 1977, defines "heavy-duty vehicle" as "a truck, bus, or other vehicle manufactured primarily for use on the public streets, roads, and highways (not including any vehicle operated exclusively on a rail or rails) which has a gross vehicle weight . . . in excess of six thousand pounds." 272

It will be remembered, perhaps, that originally the Administrator had subjected all vehicles under this weight, including trucks, to the "light-duty" standards prescribed by section 202(b). ${ }^{273}$ It may also be remembered that the court of appeals in International Harvester had held that he was wrong to do so, and that on remand, following suggestions in that opinion, he had decided that "multipurpose passenger vehicles" (which the House Report later said included "campers, minibuses, jeep-type vehicles, etc." "light-duty vehicles" either. ${ }^{275}$ In consequence, he promulgated a third set of standards, more lenient than those applicable to lightduty vehicles, ${ }^{276}$ to govern "light-duty trucks," which he defined to include multi-purpose vehicles. ${ }^{277}$

270 See note 74 supra.

271 See text and notes at notes 285-297 infra.

27242 U.S.C. $\$ 7521$ (b)(3)(C) (Supp. I 1977). One thing this definition does, as pointed out by the House Committee, is exclude locomotives and farm equipment. H.R. REP. No. 294, 95th Cong., 1st Sess. 277 (1977), reprinted in [1977] U.S. Code Cong. \& AD. NEws 1077, 1356. See text and notes at notes 627-628 infra. For present purposes, the significant aspect of the definition is the limitation to vehicles of over 6,000 pounds.

273 See text and note at note 91 supra.

${ }^{77}$ H.R. REP. No. 294, 95th Cong., 1st Sess. 271 (1977), reprinted in [1977] U.S. CoDE Conc. \& AD. News at 1350.

z7s See text and notes at notes $92-98$ supra.

27 See, e.g., 40 C.F.R. $\$ \S 86.077-9,86.078-9$ (1978), respectively prescribing 1977 and 1978 standards of, inter alia, 2.0 grams per mile of $\mathrm{HC}, 20$ of $\mathrm{CO}, 3.1$ of $\mathrm{NO}_{\mathrm{x}}$. Compare the more stringent 1977 standards for "light-duty vehicles" (0.41, 3.4, and 2.0 grams, respectively) in id. \$ 86.077-8(a)(1), and for those of "manufacturers who have been granted a suspension" (1.5, 15, 2.0 grams, respectively), in id. $\$ 86.077-8(\mathrm{a})(2)$.

27 See id. $\$ 86.077-2$ (defining a "light-duty truck" as "any motor vehicle rated at 6000 pounds [gross vehicle weight] or less, which is designed primarily for purposes of transportation of property or is a derivative of such a vehicle, or is available with special features enabling off-street or off-highway operation and use"). 
Congress in 1977 was aware of this history. The House Report noted it with evident regret, immediately following the statement that "control of new truck emissions has . . . been slower and less effective than for passenger cars." 278 So did the Senate Report, which stated its disapproval in no uncertain terms: "These vehicles should not be regulated any less stringently than automobiles. As automobiles are required to achieve greater degrees of emission control in the future, light duty truck emission standards must be tightened accordingly." 279 Yet neither bill did anything to change the definition of light-duty vehicles, which had been held to exclude light-duty trucks and campers; and the new definition of heavyduty vehicles expressly excludes them as well. The result seems to be that light-duty trucks and their relations are not subject to the statutory requirements applicable either to light-duty or to heavyduty vehicles. The Administrator may regulate them under section 202(a)(1), but his standards need neither achieve the percentage reductions ultimately applicable to both "light-duty" and "heavyduty" vehicles nor respect the strict interim heavy-duty criterion of best-available technology.

One might argue that the clear intentions of the committees should lead the courts in the future to depart from the International Harvester holding that only passenger cars are light-duty vehicles, or that by defining heavy-duty vehicles as those over 6,000 pounds Congress meant to indicate that all smaller vehicles should be considered "light-duty" ones. But International Harvester and the EPA regulations were not based on the position that small trucks were "heavy-duty vehicles"; that the statute excludes them from that category therefore does not establish that small trucks must by a process of elimination be "light-duty" vehicles. And for a committee to say it disagrees with the existing interpretation of statutory language that it chooses not to alter is hardly the most effective means of overruling that interpretation. In any event, the House Report expressly said that " $[\mathrm{b}] \mathrm{y}$ its distinction between heavy-duty and other vehicles in this bill, the Committee does not intend to preclude the Administrator from redefining the terms 'light-duty' or 'heavy-duty' or from creating new classes such as multipurpose vehicles or intermediate-duty."280

${ }^{278}$ H.R. REP. No. 294, 95th Cong., 1st Sess. 271 (1977), reprinted in [1977] U.S. CoDE Cong. \& Ad. News 1077, 1350.

${ }^{277}$ S. Rep. No. 127, 95th Cong., 1st Sess. 66-67 (1977).

2*0 H.R. REP. No. 294, 95th Cong., 1st Sess. 281 (1977), reprinted in [1977] U.S. CoDE Cong. \& AD. NEwS at 1360. 
The Administrator responded to the statute by retaining his pre-1977 definition of "light-duty trucks" as including all nonpassenger vehicles weighing less than 8,500 pounds. ${ }^{2 \times 1}$ But since vehicles between 6,000 and 8,500 pounds are "heavy-duty" vehicles under the statute, the standards for them must conform to the section 202(a)(3) criteria, and since "there is no justification for requiring trucks of less than 6000 pounds . . . to meet less stringent emission standards than heavier trucks," "the entire light-duty truck class will be subject to the requirements of section 202(a)(3)."282 Interim standards for light trucks have thus been set, ${ }^{283}$ evidently on the basis of the best technology. This approach is entirely consistent with the statute. ${ }^{284}$

\section{E. Motorcycles}

"Presently uncontrolled motorcycles," said the House Committee in 1977, "emit twice as much $\mathrm{CO}$ and six times as much $\mathrm{HC}$ as a 1976 new car." 285 At that time the Administrator, under section 202(a)(1), had just adopted emission standards for motorcycles manufactured after $1977 .{ }^{286}$ In addition to forbidding crankcase emissions, the motorcycle standards impose limits on hydrocarbon and carbon monoxide exhaust emissions. ${ }^{287}$ While these standards become more stringent in 1980 , they remain less demanding than those applicable to light-duty vehicles, and they do not apply to nitrogen oxides at all. ${ }^{288}$ Cycles of under $50 \mathrm{cc}$. engine displacement, or unable to exceed $40 \mathrm{~km}$./ $\mathrm{hr}$. or to start "using only the engine," are excluded from the regulations altogether..$^{289}$

While these regulations answered Committee concern about

281 43 Fed. Reg. 43,299 (1978).

282 Id.

${ }^{2 \times 3}$ See id. at 37,973 (adding 40 C.F.R. $\$ 86.081-9$ ).

${ }^{2 s t}$ See $\S 202(\mathrm{a})(3)(\mathrm{A})$ (iv), 42 U.S.C. $\$ 7521$ (a)(3)(A)(iv) (Supp. I 1977) (authorizing the EPA to establish classes of heavy-duty vehicles on the basis of "gross vehicle weight" and other factors); 43 Fed. Reg. 43,299 (1978).

${ }^{23 s}$ H.R. REP. No. 294, 95th Cong., 1st Sess. 273 (1977), reprinted in [1977] U.S. CoDE Cong. \& AD. NEws 1077, 1352.

2xs 40 C.F.R. $\S \S 86.401-78$ to $86.444-78$ (1978). See H.R. ReP. No. 294, 95th Cong., 1st Sess. 271 (1977), reprinted in [1977] U.S. Code Cong. \& AD. News at 1350.

287 But the regulations make no reference to fuel-evaporative emissions, as they do for light-duty vehicles and light trucks pursuant to section 202(a)(1). See, e.g., 40 C.F.R. $\S$ 86.078-8(b), -9(b) (1978).

${ }^{2 s 8} 40$ C.F.R. $\$ 86.410-80$ (1978) (the 1980 requirements are 5 grams per kilometer HC, 12 grams per kilometer $\mathrm{CO}$ ). The statutory requirements for 1978 cars are $1.5,15$, and 2.0 grams of $\mathrm{HC}, \mathrm{CO}$, and $\mathrm{NO}_{x}$ per mile. $\S 202(\mathrm{~b})(1)(\mathrm{A})$-(B), 42 U.S.C. $\S 7521(\mathrm{~b})(1)(\mathrm{A})$-(B) (Supp. I 1977).

${ }_{23} 40$ C.F.R. $\$ 86.401-78(b)$, (c) (1978). 
"uncontrolled" motorcycles, the statute was nonetheless amended to make special mention of motorcycles in response to "the prolonged delay in promulgation of adequate control measures" for them in the past. ${ }^{290}$ The Senate bill would have required that motorcycle standards be governed by the criteria applicable to heavy-duty vehicles: interim use of best technology for the three principal pollutants and percentage reductions thereafter. ${ }^{201}$ The House bill, ${ }^{292}$ which in this respect was approved, gave the Administrator a choice: under section 202(a)(3)(F), motorcycles "shall be treated in the same manner as heavy-duty vehicles . . . unless the Administrator promulgates a rule reclassifying motorcycles as light-duty vehicles . . or . . . standards applicable to . . motorcycles as a separate . . . category." 293

Since the Administrator already had prescribed standards for motorcycles "as a separate category," arguably he needed to do nothing under the new provision. On the other hand, since the separate standards were in force when the requirement was adopted, it may be that Congress expected him to give the matter a fresh look and make a new determination whether or not separate standards are desirable. To be on the safe side, the Administrator reaffirmed that motorcycles are "a separate class of vehicles" as established by the existing regulations. ${ }^{294}$

No criteria other than the general ones of section 202(a)(1) govern the Administrator's formulation of regulations for motorcycles as "a separate class or category," except that he "shall consider the need to achieve equivalency of emission reductions between motorcycles and other motor vehicles to the maximum extent practicable." ${ }^{295}$ Thus on the face of the statute, he seems free not only to ignore the relatively demanding light-duty or heavy-duty provisions, but also to preserve the present exemption of small cycles and the total omission of limits on nitrogen oxides. An argument can be made that since all "motorcycles" are made subject to all statutory heavy-duty standards unless separate provision is made, Congress meant to give the Administrator power only to prescribe different

${ }_{200}$ See H.R. Rep. No. 294, 95th Cong., 1st Sess. 273 (1977), reprinted in [1977] U.S. Code Cong. \& AD. News at 1352.

291 See S. REp. No. 127, 95th. Cong., 1st Sess. 193-94 (1977).

${ }^{202}$ See H.R. REP. No. 294, 95th Cong., 1st Sess., 274 n.16 (1977), reprinted in [1977] U.S. CODE CONG. \& AD. News 1077, 1353 n.16.

${ }^{293} 42$ U.S.C. $\$ 7521(a)(3)(F)$ (Supp. I 1977). There is an exception dealing with high altitude that is not relevant here. See text and notes at notes $99-115$ supra.

2943 Fed. Reg. 43,299 (1978).

20542 U.S.C. $\$ 7521(\mathrm{a})(3)$ (F) (Supp. I 1977). 
standards, not to exempt some vehicles or pollutants from the standards entirely. The more natural reading of the statutory language, though it means the amendment accomplished little, is that Congress, while starting with the presumption that motorcycles should be treated the same as heavy vehicles, left it to the EPA to determine the extent to which they should be treated differently.

- This conclusion is confirmed by the Conference Report's explicit declaration that "EPA's promulgated approach is consistent with the authority granted in this section, ${ }^{296}$ and the District of Columbia Circuit has relied on this passage in sustaining the Agency's definition of "useful life" for motorcycles. ${ }^{297}$

\section{Enforcement and Preemption}

\section{A. Certification}

The central machinery for enforcing the vehicle-emission standards is a certification procedure. With minor exceptions, ${ }^{298}$ section 203(a) prohibits any manufacturer from selling, and anyone from importing, new vehicles subject to the emission standards unless the vehicles are "covered by a certificate of conformity." tion 206(a) the manufacturer submits prototypes for EPA testing; the certificate is issued if the Administrator determines ${ }^{300}$ that the prototype "conforms with the regulations prescribed under section [202]." 301 The 1970 House Report explained that this meant the prototype must meet "the applicable emission standards"302_an

296 H.R. Rep. No. 564, 95th Cong., 1st Sess. 164 (1977), reprinted in [1977] U.S. CoDE Cong. \& AD. News 1502, 1544-45.

${ }^{237}$ Harley-Davidson Motor Co. v. EPA, 598 F.2d 228 (D.C. Cir. 1979). See text and note at note 338 infra.

${ }^{28 s}$ The Administrator may exempt "any new motor vehicle" or engine "for the purpose of research, investigations, studies, demonstrations, or training, or for reasons of national security." $\S 203(b)(1), 42$ U.S.C. $\$ 7522(b)(1)$ (Supp. I 1977). No mention is made of the procedure to be followed in making such exemptions. I see no reason to think Congress, by speaking in the singular of "any . . vehicle," meant to preclude making categorical exemptions by general regulation.

219 42 U.S.C. § 7522(a)(1) (Supp. I 1977).

300 Although the statute says nothing of a hearing at this stage, the regulations appropriately provide opportunity for an adjudicative hearing upon rejection of an application. 40 C.F.R. \& 86.077-6, -22 (1978).

${ }_{301} 42$ U.S.C. \& 7525(a)(1) (Supp. I 1977). Vehicles for export are sensibly subjected to the standards of the receiving country in determining whether or not to issue a certificate. 8 203(b)(3), 42 U.S.C. § 7522(b)(3) (Supp. I 1977). See H.R. REP. No. 1783, 91st Cong., 2d Sess. 200 (1970), reprinted in [1970] U.S. CODE CONG. \& AD. NEws 5374, 5382: "vehicles intended solely for export must comply with Federal emission standards unless the importing nation has differing requirements affecting motor vehicles emissions or has advised that no such requirements exist ...."

${ }^{302}$ H.R. REP. No. 1146, 91st Cong., 2d Sess. 3 (1970), reprinted in [1970] U.S. CoDE 
interpretation which, as the following discussion will show, ${ }^{302}$ was not as obvious as it may appear. ${ }^{303}$

A certificate of conformity, as the court said in United States v. Chrysler Corp., 304 "is, in effect, a license that allows an automobile manufacturer to sell vehicles to the public"; he may sell as many vehicles as he wishes so long as they are "covered by" the certificate. Just what "covered by" the certificate means, however, has been the subject of considerable controversy. The regulations prescribe that certificates authorize sale of vehicles "which conform, in all material respects, to the design specifications . . . described in the application for certification." 305 One dispute over this provision was resolved in Chrysler, where the court sensibly rejected the contention that all vehicles putatively meeting applicable emission standards were "covered" though equipped with parts different from those in the tested prototypes. The differences were "material" because the nonconforming parts could reasonably be expected to affect emission controls, and to allow conformity to be shown by a later emission test "would frustrate clear congressional intent . . . that vehicles pass emission tests before they may be sold." 306

The more serious issue is the converse: whether vehicles that do not meet emission standards are "covered" so long as they are designed in accordance with the prototype. The regulation quoted above appears to say they are, and the EPA has explained that " "the purpose of the certification program was to give the manufacturer assurance that its production cars would conform to legal requirements : . . [though their construction] differed from that of a prototype for reasons not practically . . . within the control of the manufacturer." "307

The House Report observed in 1970, however, that "[e]xperience has shown that the testing and certification of prototypes does not of itself assure that automobiles coming off the assembly line . . . comply with the Federal emission standards." ${ }^{308}$ One reason for that experience was described in the Nader Report: "[P]rototypes are handmade, individually machined to greater

\footnotetext{
Cong. \& AD. NEws 5356, 5358. This language was identical to that on which the report was commenting.

${ }^{303}$ See text and notes at notes 307-360 infra.

${ }^{304} 591$ F.2d 958, 960 (D.C. Cir. 1979).

${ }^{305} 40$ C.F.R. \& 86.077-30(a)(2) (1978).

${ }^{300} 591$ F.2d at 961 .

${ }^{307}$ W. RoDGERs, supra note $36, \S 3.15$, at 307 (quoting 1 EPA Collection of Legal Op. Dec. 1970-Dec. 1973, at 184) (emphasis in original).

${ }^{30 s}$ H.R. REP. No. 1146, 91st Cong., 2d Sess. 3 (1970), reprinted in [1970] U.S. Code CoNg. \& AD. NEws 5356, 5358.
} 
than production-line tolerances, carefully serviced, and handadjusted."309 Thus, by 1970 Congress was aware that certification was not serving what Professor Rodgers has persuasively described as another of its central purposes: "to approve the sale of vehicles in a production line only after an adequate showing that the cars will meet emission requirements." 310

The original statute had expressly forbidden sale of vehicles not meeting emission standards. ${ }^{311}$ The apparent objective of this injunction was, however, contradicted by a provision that vehicles "of substantially the same construction as the prototype" were "deemed" to meet emission standards. ${ }^{312}$ Against the background of widespread failure of mass-produced cars to perform as well as the prototypes, Congress repealed the "same construction" proviso in $1970 .{ }^{313}$ Standing alone, this action would suggest that design conformity should no longer be a defense to a charge of selling uncertified vehicles. But at the same time, Congress substituted the present term "covered by" the certificate for the pre-existing requirement that production vehicles meet the emission standards; it also added new and distinct remedies for the gap between prototype and production, which are discussed in the following subsections. This history, reinforced by the phrasing of the House Report, ${ }^{314}$ suggests that vehicles not meeting the standards may nonetheless be "covered by" the certificate and therefore may be sold so long as it remains in force, but that production failures may subject the manufacturer to a variety of remedial actions including revocation of the certificate.

\section{B. Production-Line Testing}

Section 206(b), responsive to the failure of production vehicles to measure up to the prototype, ${ }^{315}$ since 1970 has authorized the EPA

${ }^{302}$ J. Esposito, VANishing ArR 54 (1970).

3to W. RoDGers, supra note $36, \S 3.15$, at 307 .

31 Clean Air Act Amendments of 1965, Pub. L. 89-272, § 101(8), 79 Stat. 993 (amending Clean Air Act $\S 203(a)(1)$ ) (current version at 42 U.S.C. $\S 7522(a)$ (1) (Supp. I 1977)).

312 Id., 79 Stat. 994 (amending Clean Air Act $\$ 206(\mathrm{~b})$ ) (current version at 42 U.S.C. $\S$ 7525(b) (Supp. I 1977)).

${ }^{313}$ Clean Air Act Amendments of 1970, Pub. L. 91-604, § 8(a), 84 Stat. 1694 (amending Clean Air Act $\S 206(b)$ ) (current version at 42 U.S.C. $\S 7525$ (b) (Supp. I 1977)).

314 "[A] manufacturer may not sell . . . any vehicle or engine to which an emission standard applies, unless such vehicle or engine is covered by a certificate of conformity. . . . [A] certificate may be suspended or revoked if the secretary's production-line testing shows that vehicles or engines covered by it do not actually meet the applicable emissions standards." H.R. Rep. No. 1146, 91st Cong., 1st Sess. 12 (1970), reprinted in [1970] U.S. Code Cong. \& AD. News 5356, 5368.

${ }^{315}$ Id. at 3, reprinted in [1970] U.S. Code CoNG. \& AD. NEws at 5358. 
to conduct production-line tests to determine "whether . . . vehicles . . . being manufactured . . . do in fact conform with the regulations with respect to which the certificate . . . was issued." "316 It also permits the EPA to revoke or suspend the certificate, with opportunity for a subsequent record hearing, ${ }^{317}$ upon a finding that "all or part" of the vehicles or engines covered do not so conform. ${ }^{318}$

For a long time this production-testing authority was not exercised, and significant failures of production vehicles to meet the standards were reported. ${ }^{319}$ In 1976 , the EPA finally adopted a "selective enforcement audit" procedure (SEA) for testing a sample of light-duty production vehicles. ${ }^{320}$ In devising the procedure, the crucial issue was once again the basis on which conformity was to be determined. One possible interpretation would have been that a vehicle satisfied "the regulations with respect to which the certificate . . . was issued," and thus met the production-line requirement, whenever it was "covered by" the certificate; production testing might have been only a means of assuring conformity to the original design. Since a major cause of inadequacy of emission controls on production vehicles was that a prototype was not representative of its design, such an interpretation would render production testing insufficient to accomplish its purpose. Moreover, while the language of compliance for production testing suggestively differs from the requirement of section 206(a) that a prototype be tested for conformity with "the emission regulations prescribed under section [202],"321 the House Report explaining the production-testing

s16 42 U.S.C. $\S 7525(\mathrm{~b})(1)$ (Supp. I 1977).

${ }^{317}$ Id. $\$ 7525$ (b)(2)(B)(i). The importance of protecting public health should justify postponing the hearing until after suspension or revocation, so long as the hearing is promptly held. Cf. Commissioner v. Shapiro, 424 U.S. 614 (1976) (dictum) (seizure of absconding taxpayer's property before hearing); North Am. Cold Storage Co. v. City of Chicago, 211 U.S. 306 (1908) (ordinance requiring destruction of contaminated food before opportunity for hearing).

${ }^{318} 42$ U.S.C. $\$ 7525(\mathrm{~b})(2)$ (A) (Supp. I 1977). Vehicles may be certified on an individual basis after suspension or revocation of the prototype certificate. Id.

31. See S. REP. No. 127, 95th Cong., 1st Sess. 85 (1977). The 1977 Senate bill, id. at 201, would have required a production-line test procedure to be established within six months. The Conference Committee deleted this requirement, noting the EPA had just adopted the selective auditing procedure described below. Calling this only "a first step," the report added that "the conferees intend that the Administrator revise current test procedures expeditiously to provide a short production line test . . . to assure reasonable statistical certainty that each car produced will be able to pass" a comparable emissions inspection. H.R. REP. No. 564, 95th Cong., 1st Sess. 171 (1977); reprinted in [1977] U.S. Code CoNG. \& AD. NEws 1502, 1552. The EPA had given the 45-minute length of the existing test as one reason for testing only a small sample of vehicles. 41 Fed. Reg. 31,472 (1976).

30 C.F.R. $\$ \$ 86.601-.613$ (1978).

32142 U.S.C. \& 7525(a) (Supp. I 1977). 
provision explicitly stated that the criterion was conformity "to the emission standards." 322 The SEA rules therefore quite properly provide for determining whether production vehicles meet applicable emission standards..$^{323}$

Thus it appears that, while a certificate covers every vehicle that conforms to the prototype, production-line testing is to determine whether the individual vehicle meets applicable emission standards. There is no necessary.inconsistency here. By prescribing different criteria, the statute seems to have attempted to promote the twin goals of certification as described above. So long as the certificate is in existence, the manufacturer is protected against money penalties or a shutdown order; but the certificate may be revoked, and the public interest protected, if the prototype turns out to be better than its descendants.

The question remains whether each vehicle tested must meet the standards or whether, as the manufacturers contended, compliance should be determined by averaging the emissions of all vehicles in a certified class. ${ }^{324}$ Averaging may be quite compatible with the rollback calculus by which the statutory standards were initially determined, ${ }^{325}$ but section $206(\mathrm{~b})$ itself authorizes revocation of the entire certificate when "all or part" of the vehicles tested fail to conform; ;26 a certificate may also be revoked "insofar as" it "applies to" any individual vehicle that fails the test. ${ }^{327}$ Moreover, section 207(b) provides that each vehicle sold shall be warranted to "conform ... during its useful life ... to the regulations prescribed under section [202]," as soon as there is technology for determining compliance "with the emission standards of such regulations." 328 The Conference Report confirms that this is a warranty for every car of actual compliance "with applicable emission standards." ${ }^{29}$ The warranty provision thus demonstrates that Congress,

${ }^{322}$ H.R. REP. No. 1196, 91st Cong., 2d Sess. 11-12 (1970), reprinted in [1970] U.S. CoDE Cong. \& AD. News 5356, 5367.

${ }^{323}$ See 40 C.F.R. Part 86, Subpart G, App. IX (1978).

32441 Fed. Reg. 31,472, 31,480 (1976). Averaging is condemned in Jorling, supra note.36, at $1118-19$.

${ }^{323}$ See text and notes at notes $39-40$ supra.

324 42 U.S.C. $\$ 7525(\mathrm{~b})(2)$ (A)(i) (Supp. I 1977).

327 Id. $\S 7525(\mathrm{~b})(2)(\mathrm{A})(\mathrm{ii})$.

${ }^{323}$ Id. § 7541(b). See text and notes at notes $341-360$ infra.

H.R. Rep. No. 1783, 91st Cong., 2d Sess. 51 (1970), reprinted in [1970] U.S. Cods Cong. \& AD. News 5374, 5383. See also \& 206(g)(4), .42. U.S.C. \& 7525(g)(4) (Supp. I 1977) (providing an exception to the general rule by prescribing a warranty based upon the emission levels permitted by a certificate issued to nonconforming heavy-duty vehicles subject to nonconformance penalties, "and not for the emission levels required under the applicable standard"). 
subject only to the development of testing technology, contemplated legal sanctions to assure that each vehicle met the emission standards; to determine substantive compliance on an averaging basis would be inconsistent with section 207(b), and the EPA explicitly so decided. . $^{330}$

Nevertheless, the manufacturers had proceeded on the assumption that averaging was permissible; and to avoid imposing an "unreasonably burdensome" requirement, ${ }^{331}$ the EPA regulations provide that only $60 \%$ of production-line vehicles must meet emission standards to avoid revocation of the certificate under section 206(b). ${ }^{332}$ Technically, this seems not to violate the statute, which gives the Administrator apparently broad discretion in the use of this sanction: he "may" revoke on failure by "all or part" of the vehicles tested. Yet it is not easy to reconcile this free pass with the substantive requirement of compliance by each vehicle. If the warranty provisions had been in force, revocation of the certificate of conformity would have avoided the inefficiency and tardiness of widespread warranty repairs by keeping nonconforming cars off the market; in the absence of warranties, revocation is all the more indispensable if the substantive emission standards are to be met at all. ${ }^{333}$

\section{Compliance in Use: Warranties}

The EPA's authority to adopt vehicle-emission standards is limited to "new" vehicles and engines, ${ }^{334}$ which are defined by section 216 as those that have "never been transferred to an ultimate purchaser," 335 who is "the first person who in good faith purchases . . . for purposes other than resale." 336 Yet Congress could no more afford to ignore the gap between initial and later performance than

${ }^{330} 41$ Fed. Reg. 31,472, 31,480 (1976).

ssi Id. at 31,474 .

33240 C.F.R. $\S \S 86.602(a)(1), .607(b)$ (1978).

333 In proposing to extend the SEA procedure to heavy-duty vehicles, the EPA has set forth a $90 \%$ compliance requirement, and the new emission standards have been designed with that requirement in mind. 44 Fed. Reg. 9464, 9468, 9490 (1979) (proposing, inter alia, a new 40 C.F.R. $\$ 86.1010-83$ (a)). When the failure rate becomes as low as $10 \%$, revocation of the entire certificate may be an unreasonably harsh remedy for expectable variability in production. Inspection and warranty, see notes 341-360 infra, may be a preferable enforcement scheme under those circumstances. An alternative without the advantage of testing for later deterioration would be testing of every vehicle at the production line, which the EPA has rejected as not cost justified. See 41 Fed. Reg. 31,472 (1976).

33 § 202(a)(1), 42 U.S.C. $\$ 7521(a)(1)$ (Supp. I 1977).

35542 U.S.C. \& 7550(3) (Supp. I 1977).

${ }^{338}$ Id. $\S 7550(5)$. 
it could ignore that between prototype and production. Emission standards consequently "shall be applicable to such vehicles and engines for their useful life." 337

Section 202(d)(1) defines the "useful life" of a light-duty vehicle as "five years or fifty thousand miles . . . whichever first occurs." 338 One observer cites this definition as an example of industry's success in weakening the emission standards by manipulating the relatively invisible provisions for their implementation: although the statute rhetorically trumpets "that cars must conform 'for their useful life,' elsewhere 'useful life' is defined as what, in practice, is only half the useful life of the car." 339 It is impossible to say that this sleight-of-hand really undermines the statutory policy, however, without knowing whether or not the rollback model by which the emission standards were determined envisioned that cars would conform to emission requirements as long as they were on the road.

The first consequence of the useful-life provision is that certification is dependent upon the test vehicle's compliance with standards not only when it is new but also until it has been driven for 50,000 miles "or such lesser distance as the Administrator may agree to. ${ }^{\prime 340}$ One cannot very well run every car 50,000 miles before it is

$337 \S 202(a)(1), 42$ U.S.C. $\S 7521(a)(1)$ (Supp. I 1977).

33842 U.S.C. $\$ 7521(d)(1)$. In the case of motorcycles, "useful life" is to be "a period of use the Administrator shall determine," § 202(d)(3), 42 U.S.C. $\S 7521$ (d)(3) (Supp. I 1977). The Senate Report said the EPA should have flexibility to determine a "reasonable mileage standard" in view of the fact that motorcycles, while requiring "effective controls," "simply do not last 50,000 miles." S. REP. No. 127, 95th Cong., 1st Sess. 77-78 (1977). The motorcycle regulations define "useful life" as five years or from 7,456 to 18,641 miles according to the size of the engine. 40 C.F.R. $\$ 86.402-78$ (1978). Manufacturers contended these definitions were improper because they were based upon actual expected lifetime travel distance in contrast to the statutory automobile standard, which they argued was only half the actual expected life. Harley-Davidson Motor Co. v. EPA, 598 F.2d 228, 230 (D.C. Cir. 1979). The court disagreed: as the Senate Report had said, flexibility was intended, and the Conference Report had expressly approved the existing motorcycle standards. Id.

For other vehicles, the 5-year, 50,000-mile light-duty definition applies "unless the Administrator determines that a period of use of greater duration or mileage is appropriate." $\S 202(d)(2), 42$ U.S.C. $\S 7521$ (d)(2) (Supp. I 1977). Deeming the 50,000-mile and 100,000mile definitions respectively set, 40 C.F.R. $\$ 86.077-2$ (1978), for gasoline-powered and dieselpowered heavy-duty vehicles "unrealistically short," 44 Fed. Reg. 9464, 9466 (1977), the EPA has proposed to substitute "the average period of use up to engine retirement or rebuild, . . . as determined by the manufacturer based on survey information of in-service engines or, for new engines, based on durability testing of prototype engines"-with a statutory floor of the light-duty definition. Id. at 9474 (proposing a new 40 C.F.R. $\$ 86.083-2$ ). The aim is to "bring the definition of useful life into clear agreement with the periods of use actually seen by heavy-duty engines." Id. at 9466.

339 Margolis, The Politics of Auto Emissions, 49 Pub. Interest 3, 16 (1977).

s10 40 C.F.R. $\S 86.077-26(a)(4)$ (1978). See W. RoDGERs, supra note 36, § 3.14, at 295 
sold, so the useful-life provision is further backed up by the warranty provisions of section 207.

Two distinct warranties are provided. The first, in section 207(a), is a design and construction warranty: that the vehicle or engine "is (A) designed, built, and equipped so as to conform at the time of sale with applicable regulations . . . , and (B) free from defects . . . which cause such vehicle . . . to fail to conform . . . for its useful life."341 The warranty runs to the "ultimate purchaser and each subsequent purchaser." ${ }^{342}$ Presumably the consequence of a breach is an obligation to make the purchaser whole, but for what loss the statute does not say.

The design warranty seems to cover only vehicles whose poor performance is caused by an identifiable flaw. Section 207(b) ${ }^{343}$ therefore supplements it with a warranty of actual performance, to assure that each vehicle will "conform . . . during its useful life . . . to the regulations prescribed under section [202]"344_that is, as the Conference Report said, ${ }^{345}$ that each vehicle will meet the applicable emission standards, rather than simply conform to prototype design. In case of breach, the "manufacturer shall remedy such nonconformity" at his own expense. . $^{346}$

This warranty, however, is qualified. It applies, appropriately enough, only if "the vehicle or engine is maintained and operated in accordance with instructions"; $; 47$ the manufacturer is not responsible if the owner mistreats his car. Moreover, in order to allay fears of an anticompetitive effect on the market for replacement parts, ${ }^{348}$ the 1977 amendments limited the performance warranty to two

(arguing that the Administrator's decision to allow one replacement of the catalyst at the owner's expense is inconsistent with the useful-life requirement); Jorling, supra note 36, at 1119-21 (same).

311 42 U.S.C. \& 7541(a)(1) (Supp. I 1977).

312 Id.

${ }^{343}$ Id. 7541(b).

${ }^{34}$ Id. $\S 7541(\mathrm{~b})(2)(\mathrm{B})$.

315 See text at note 329 supra.

s4 42 U.S.C. $\$ 7541$ (b)(2) (Supp. I 1977).

347 Id. $\$ 7541(\mathrm{~b})(2)(\mathrm{A})$.

${ }^{348}$ See H.R. REp. No. 294, 95th Cong., 1st Sess. 291-92 (1977), reprinted in [1977] U.S. Code Cong. \& AD. News 1077, 1370-71.

A bevy of provisions was added in 1977 to calm fears that the warranty provisions might give the vehicle manufacturer a competitive advantage in the market for replacement parts. Absent a showing of necessity, he may not condition the warranty on use of brand-name parts or services provided by his affiliates; he must inform the buyer that there are no such limitations; the EPA is required to certify competing replacement parts if they "enable such vehicle or engine to conform" to mandatory light-duty standards. \$206(a)(2), 42 U.S.C. \$7525(a)(2) (Supp. I 1977). See also § 207(c)(3)(A)-(B), 42 U.S.C. $\$ 7541(c)(3)(A)-(B)$ (Supp. I 1977). 
years or 24,000 miles except for "a catalytic converter, thermal reactor, or other component installed . . . for the sole or primary purpose of reducing vehicle emissions." 349 Further, and most importantly, the performance warranty does not take effect until the Administrator determines that adequate inspection procedures have been established and correlated with the tests that are performed as a condition of certification. By the time of the 1977 amendments the performance warranty was not yet in effect "because no short, in-use test [was] available";350 the EPA has since declared that test procedures will be approved in time to make the warranty applicable to 1980 vehicles. ${ }^{351}$

On its face the performance warranty, once in effect, is subject to still another limitation; under section 207(b)(2)(C), it applies only if the owner is required as a result of nonconformity "to bear any penalty or other sanction (including the denial of the right to use such vehicle or engine) under State or Federal law."352 Unaccountably, the owner may not require the manufacturer to fix his car unless the owner has been punished under some inspection scheme. ${ }^{353}$ This limitation, however, seems to have been effectively repealed by the addition of section $207(\mathrm{~h})$ in 1977:

If at any time during the period for which the warranty applies under subsection (b) of this section, a motor vehicle fails to conform to . . . regulations under section [202] . . . as determined under subsection (b) of this section such nonconformity shall be remedied by the manufacturer at the cost of the manufacturer pursuant to such warranty as provided in subsection (b)(2) of this section (without regard to subparagraph (C) thereof). ${ }^{354}$

It was subparagraph (C) that required the purchaser to incur penalties before seeking repair at the manufacturer's expense. Apparently the new provision leaves unimpaired the other requirements of the

34 $\S 207(\bar{b}), 42$ U.S.C. $\$ 7541$ (b) (Supp. I 1977). This is achieved by an awkward definition of the warranted "emission control device or system," which has a broader meaning during the two-year or 20,000-mile period. See H.R. REP. No. 564, 95th Cong., 1st Sess. 168 (1977), reprinted in [1977] U.S. CODE CONG. \& AD. News 1502, 1548-49. I should have thought the additional antimonopoly provisions adopted, see text and note at note 348 supra, would have made this retrenchment of the warranty unnecessary.

${ }_{330}$ S. REP. No. 127, 95th Cong., 1st Sess. 81 (1977).

s5i See 44 Fed. Reg. 23,784, 23,785, 23,788 (1979).

35242 U.S.C. $\$ 7541$ (b)(2)(C) (Supp. I 1977).

3ss Oddly, in light of this requirement, the statute does not say the owner is entitled to reimbursement for his penalties.

3s4 42 U.S.C. \& 7541(h)(2) (Supp. I 1977). 
warranty section; $;^{355}$ needless to say, Congress could have accomplished the goal with much less risk of confusion by simply repealing the penalty requirement in section 207 (b) itself. ${ }^{356}$

The EPA, noting that "[p]arentheticals in one section of a law do not generally void other subsections," 357 has interpreted the new provision of section $207(\mathrm{~h})$ as dispensing with the penalty prerequisite only if the vehicle fails an emission test within three months after its initial sale. ${ }^{358}$ At the same time, however, the EPA considers the penalty requirement of subparagraph (C) satisfied whenever the owner is ordered to repair his car after failing an inspection, at the risk of future penalties. ${ }^{359}$ Needless to say, both these readings are difficult to square with the statute.

Independent of the warranty provisions, howevex, and without regard to the limitations in those sections, section $207(\mathrm{c})$ requires the Administrator to order a recall on finding that "a substantial number of any class or category of vehicles or engines, although properly maintained and used, do not conform to the regulations prescribed under section [202]." The manufacturer must then remedy the "nonconformity" at his own expense. ${ }^{360}$

${ }^{355}$ The effect of this masterpiece of circumlocution is not wholly clear even after careful parsing. It does not repeal the requirement of a finding that adequate inspection procedures have been established, since it applies only "during the period for which the warranty applies under subsection (b)." For the same reason, I think it does not affect the limitation of the warranty after two years or 20,000 miles, though technically that limitation is phrased as a definition of the devices covered rather than as a limit of the warranty's duration. I should also conclude, since no one expressed dissatisfaction with it, that Congress did not mean to eliminate the salutary requirement that the owner not have mistreated his vehicle, though the reference to a failure to conform "as determined under subsection (b)" does not clearly incorporate requirements that that subsection appears to state as additional to that of nonconformity. The Conference Report loosely says the manufacturer is responsible whenever " $\mathrm{a}$ motor vehicle fails an in-use emissions test," without mentioning proper maintenance, but the thrust of this remark seems to be an indication that no imposition of penalties is requisite. H.R. REP. No. 564, 95th Cong., 1st Sess. 170 (1977), reprinted in [1977] U.S. CodE Cong. \& AD. NEws 1502, 1550-51.

3ss In addition, section 207(h)(1), 42 U.S.C. $\S 7541(\mathrm{~h})(1)$ (Supp. I 1977), requires the dealer to certify that the vehicle "conforms to the applicable regulations under section [202]," but no remedies against the dealer are provided in case of test failure. To avoid making the certificate "a meaningless piece of paper," the EPA proposed to require the dealer to certify that the vehicle is covered by certificate, that visual inspection shows emissioncontrol components to be installed and apparently functioning, and that he has performed any necessary presale preparation. See 44 Fed. Reg. 23,793, 23,796 (1979) (proposing a new 40 C.F.R. $\$ 85.2108($ b)).

35744 Fed. Reg. 23,793 (1979).

3ss Id. at 23,793, 23,797 (proposing a new 40 C.F.R. $\$ 85.2108(\mathrm{~d})$ )).

359 Id. at 23,791, 23,796 (proposing a new 40 C.F.R. $\$ 85.2106(\mathrm{a})$ ).

${ }^{340} 42$ U.S.C. $\$ 7541$ (c)(1) (Supp. I 1977). See Jorling, supra note 36, at 1122 (arguing that the requirement of a "substantial" number of violations "should be read to impose a reasonable man test on the likelihood that the cause of the malfunction in those vehicles found 


\section{Tampering}

The provisions we have so far considered apply only to manufacturers and importers; nothing is said of any duty on the part of the owner to keep his vehicle in compliance with emission standards. Section 203(a), however, takes a small step in that direction by limiting the owner's ability to get professional help in sabotaging the emission-control system the manufacturer is required to install.

The pre-1977 provisions forbade any person prior to delivery to the "ultimate purchaser," and "any manufacturer or dealer" thereafter, to "remove or render inoperative any device or element of design installed on or in a motor vehicle . . . in compliance with regulations under this subchapter"-"knowingly" in the case of tampering after delivery. ${ }^{361}$ The obvious deficiency was that the statute left it open to "any person independent of a manufacturer" to "disconnect a pollution control system without penalty" 362 after delivery. Thus the Senate Report in 1977 noted:

In the wake of the fuel crisis of 1974 and the resulting national concern over fuel economy, many private service garages advertised extensively their emission control removal services, allegedly to produce increases in fuel economy. Emission control removal manuals were marketed. Studies by the Environmental Protection Agency . . . indicate that such practices assure only that emissions will increase dramatically and usually without any improvement in fuel economy. ${ }^{363}$

Accordingly, the 1977 amendments extend the prohibition of knowing post-delivery tampering to "any person engaged in the business of repairing, servicing, selling, leasing, or trading motor vehicles or motor vehicle engines, or who operates a fleet of motor vehicles." ${ }^{364}$

actually not in compliance would indicate that other vehicles in a production class are not in compliance"); 8 ENVIR. REP. (BNA) 1594 (1978) (decision of an administrative law judge upholding an order to Chrysler to recall vehicles for nonconformity to carbon monoxide standards).

sot Air Quality Control Act of 1967, Pub. L. No. 90-148, § 2, 81 Stat. 500 (amending Clean Air Act $\$ 203$ (a)(3)), as amended by Clean Air Act Amendments of 1970, Pub. L. No. 91604, § 7, 84 Stat. 1693 (amending Clean Air Act $\$ 203$ (a)(3)) (current version at 42 U.S.C. $\$$ 7522(a)(3) (Supp. I 1977)).

${ }^{302}$ S. REP. No. 127, 95th Cong., 1st Sess. 78 (1977).

3s Id. An EPA study reports that pollution controls on $48 \%$ of $1973-1978$ cars had been "altered." 9 ENVIR. REP. (BNA) 1508 (1978).

su $\$ 203(a)(3)(B), 42$ U.S.C. $\$ 7522(a)(3)(B)$ (Supp. I 1977). The terms of the prohibition are the same as those applicable to manufacturers and dealers in id. $\S 7522(a)(3)(\mathrm{A})$. The penalties are higher for manufacturers and dealers, see $\$ 205,42$ U.S.C. $\$ 7524$ (Supp. I 1977), but a less prolix way to express that distinction could have been found than the addition of an entire separate subparagraph. 
Significant gaps in coverage remain. As the House Report emphasized, the law still does not outlaw tampering by "individual motorists"; ${ }^{365}$ apparently Congress was unwilling to commit federal resources to the unpromising task of policing individual tampering. Moreover, the statute does nothing about the distribution of "emission control removal manuals"; indeed, so long as owner tampering is not forbidden, the first amendment probably protects the right to incite and abet it. "F66 "Fleet of motor vehicles" is not defined; there may be line-drawing problems that could have been avoided by inserting a number, but the Committee's reference to "individual motorists" ought to protect the three-car suburban family's right to undermine important federal policy.

On its face the tampering provision seems in some respects too broad, while in others too narrow. The mechanic who temporarily disconnects a control device while repairing it has literally done what the statute forbids, though both committees made clear that he was not meant to be covered; ${ }^{367}$ qualifying language should have been put in the statute itself. Conversely, while the Senate Committee stated flatly that "[t]ampering . . . extends to the purposeful setting of engine adjustments to other than manufacturers' recommended specifications, "388 it is not obvious that to reset the carburetor so as to impair emission control is to "render inoperative" any "installed" "device or element of design." Fortunately, the legislative history is confirmed by section 215(a)(1), which, by sensibly making the tampering ban inapplicable to adjustments made to compensate for high-altitude problems without impairing emission control, ${ }^{369}$ implies that other adjustments constitute tampering. This could have been placed beyond the vagaries of judicial interpretation by the insertion of a few words..$^{370}$

${ }^{365}$ H.R. REP. No. 294, 95th Cong., 1st Sess. 298 (1977), reprinted in [1977] U.S. CoDE CoNG. \& AD. NEws 1077, 1377.

${ }^{366}$ See Virginia State Bd. of Pharmacy v. Virginia Citizens Consumer Council, 425 U.S. 748 (1976).

36 H.R. REP. No. 294, 95th Cong., 1st Sess. 298 (1977), reprinted in [1977] U.S. CoDE Cong. \& AD. News at 1377 (quoting United States v. Haney Chevrolet, Inc., 371 F. Supp. 381, 384 (M.D. Fla. 1974) (dictum)); S. REP. No. 127, 95th Cong., 1st Sess. 79 (1977).

${ }^{s t s}$ S. REP. No. 127, 95th Cong., 1st Sess. 78 (1977) (giving as an example "the setting of the idle fuel flow to resuit in excessively rich mixtures").

36342 U.S.C. \& 7549(a)(1) (Supp. I 1977).

570 The tampering provision was enforced in a 1974 district court decision against a Florida dealer whose employee had removed the "idle speed solenoid" and "render[ed] inoperative the transmission control spark system" after sale to the ultimate purchaser. United States v. Haney Chevrolet, Inc., 371 F. Supp. 381, 384 (M.D. Fla. I974). The only serious defense was that the action had been taken "only temporarily until a solution to the Corvette's engine problems could be found." Id. The court held this no excuse: 
E. Remedies

In addition to certification, production-line testing, recall, and warranties, two principal tools are provided to enforce the prohibitions of the vehicle-emission sections. Section 204 authorizes injunctive actions by the United States ${ }^{371}$ and section 205 the imposition of "civil" money penalties. ${ }^{372}$

The injunctive provision extends to all "violations of section [203(a)]," which include not only the sale and importation of uncertified vehicles ${ }^{373}$ but also tampering, ${ }^{374}$ failure to supply requisite information, ${ }^{375}$ failure to follow labelling requirements, ${ }^{376}$ and violation of various warranty and recall provisions. ${ }^{377}$

The penalty provision applies to the same violations. For postdelivery tampering by one who is not a "manufacturer or dealer," the maximum penalty is $\$ 2,500$; for all other violations it is $\$ 10,000.378$ Except for violations of the information provisions in section 203(a)(2), "[a]ny violation . . . shall constitute a separate offense with respect to each motor vehicle or motor vehicle engine." 379 Obviously, penalties of this magnitude could make noncompliance unattractive. While nothing is said as to who may sue for penalties, the tradition of government enforcement is so strong that it would take explicit language to authorize penalties at the suit of private parties.

There is no mention of injunctive or damage suits by affected individuals, and the citizen-suit provision of section 304 authorizes private enforcement only of specified requirements not including

[A]n act is done knowingly when it is done voluntarily and intentionally, and not by mistake or accident. . . [T] [Te prohibited act of "removal or rendering inoperative a device or element of design" is complete . . . when the dealer voluntarily removes or renders inoperative the emission control devices or elements . . . and voluntarily relinquishes custody and control of the vehicle . . . with the ... devices or elements . . . removed or rendered inoperative.

Id. The House Report explicitly endorsed this interpretation in both respects. H.R. REP. No. 294, 95th Cong., 1st Sess. 298 (1977), reprinted in [1977] U.S. Code Cong. \& AD. News 1077, 1377.

37142 U.S.C. § 7523 (Supp. I 1977).

372 Id. $\$ 7524$. Exclusion from the country is an additional remedy provided for importation of uncertified vehicles. Id. $\S 7522(\mathrm{~b})(2)$.

${ }^{73} 42$ U.S.C. § 7522(a)(1) (Supp. I 1977).

s74 Id. § 7522(a)(3)(A)-(B).

I75 Id. \& 7522(a)(2).

37 Id. $\S 7522(\mathrm{a})(4)(\mathrm{A})$.

${ }^{377}$ Id. \& 7522(a)(4)(A)-(D).

mi \& 205, 42 U.S.C. \& 7524 (Supp. I 1977).

337 Id. 
those of section 203. ${ }^{380}$ Though a citizen may sue to compel the Administrator himself to perform nondiscretionary acts required by the vehicle-emission sections, ${ }^{381}$ and private relief is implicit in the warranty provisions, ${ }^{382}$ the availability of other private relief is left to general law. ${ }^{383}$

\section{F. Nonconformance Penalties}

Normally the EPA issues a "certificate of conformity" only if the prototype "conforms with the regulations prescribed under section [202]," ${ }_{384}$ and normally the manufacturer is expected not to sell production vehicles without such a certificate. ${ }^{385}$ An interesting exception to this pattern was made in 1977 by the addition of section $206(\mathrm{~g}) .^{386} \mathrm{In}$ order to avoid either rewarding the "laggard's" behavior by relaxing the standard or "ruling the "laggard' out of the market" by prohibiting his sales, ${ }^{387}$ section $206(\mathrm{~g})$ innovatively provides that "a certificate of conformity shall be issued" for heavy-duty vehicles, and "may be issued" for motorcycles, ${ }^{388}$ "notwithstanding the failure . . . to meet such standard if [the] manufacturer pays a nonconformance penalty." 380 This provision is, on its face, inapplicable to light-duty vehicles.

${ }^{380} 42$ U.S.C. $\$ 7604$ (a), (f) (Supp. I 1977). While section 304 applies to "violation" of any "emission . . . limitation under this chapter," id. $\$ 7604$ (a)(1), no provision forbids emissions in excess of vehicle standards as such; what is prohibited is sale of uncertified vehicles.

${ }^{381}$ Id. $\$ 7604(a)(2)$ ("any act or duty under this chapter which is not discretionary").

382 See text and notes at notes 341-360 supra.

${ }^{383}$ See Cort v. Ash, 422 U.S. 66 (1975). The enforcement provisions of section 113, including administrative orders and criminal sanctions, do not apply to motor-vehicle violations. 42 U.S.C. $\$ 7413$ (Supp. I 1977). The existence of two separate enforcement schemes under the same statute seems the result of history rather than design.

ss $\S 206(a)(1), 42$ U.S.C. $\$ 7525(a)(1)$ (Supp. I 1977).

${ }^{385} \S 203(\mathrm{a})(1), 42$ U.S.C. $\$ 7522(\mathrm{a})(1)$ (Supp. I 1977) (prohibiting such sales).

38842 U.S.C. \& 7525(g) (Supp. I 1977).

${ }^{387}$ See H.R. Rep. No. 294, 95th Cong., 1st Sess. 275 (1977), reprinted in [1977] U.S. Code Cong. \& Ad. News 1077, 1354.

${ }^{38 s}$ See H.R. REP. No. 564, 95th Cong., 1st Sess. 164 (1977), reprinted in [1977] U.S. CODE Cong. \& AD. News 1502, 1544 ("the provision . . . authorizes but does not require, the Administrator to permit the sale of nonconforming motorcycles upon payment of a . . . penalty") (emphasis added). The House bill had included motorcycles in the "shall" provision later limited to heavy-duty vehicles. See H.R. REP. No, 294, 95th Cong., 1st Sess. 420 (1977).

${ }^{389} 42$ U.S.C. $\$ 7525(\mathrm{~g})(1)$ (Supp. I 1977). Similarly, while later proof of nonconformity normally is a ground for revocation or suspension of the certificate, id. $\S 7525(\mathrm{~b})(2)(\mathrm{A})(\mathrm{i})-$ (ii), section $206(\mathrm{~g})(1)$ makes payment of the penalty proof against revocation or suspension as well in the case of heavy-duty vehicles. The omission of any reference to suspension or revocation in the case of motorcycles is consistent with the discretionary nature of nonconforming certification of motorcycles, since suspension and revocation in any case "may" rather than "shall" be ordered. 
There is a limiting condition, however: "no certificate . . may be issued . . . if the degree by which the manufacturer fails to meet any standard . . . exceeds the percentage determined under regulations . . . to be practicable." 390 In what appears to accord with the statutory term "practicable," the EPA has said it will set upper limits that "correspond to the lowest emission level which the Agency determines any technological laggard has the capability of achieving," so that "no manufacturer would be forced to suspend engine production when the new standards go into effect." ${ }^{391}$

The amount of the penalty may vary by pollutant or vehicle class but "shall take into account the extent" of nonconformity ${ }^{392}$ "shall be increased periodically in order to create incentives," "393 and "shall remove any competitive disadvantage" to complying manufacturers. ${ }^{394}$ The Conference Committee explained that in order to remove that disadvantage the penalty

would include such items as the actual cost of compliance for complying vehicles, the capital costs foregone as a result of non-compliance, the market value of any fuel economy gains made by non-complying vehicles compared to complying vehicles and the competitive advantage that may arise because of the lesser warranty and recall obligations. ${ }^{395}$

Penalties so determined should reasonably well serve the twin purposes of creating an incentive to comply with the emission standards and promoting equitable treatment of competitors.

Nothing is said of the procedure whereby the amount of the individual manufacturer's penalty is determined. ${ }^{396}$ In the analogous situation of a suspension or revocation of a manufacturer's certificate for failure to meet the applicable standard, the statute provides the manufacturer a right to a "hearing" and a "determination on the record";387 these provisions trigger the full adjudicatory proce-

3N Id. § 7525(g)(2).

III 44 Fed. Reg. 9464,9470 (1979). The House Report spoke vaguely of "an allowable range" on nonconformity. H.R. RBP. No. 294, 95th Cong., 1st Sess. 275 (1977), reprinted in [1977] U.S. CoDE CoNg. \& AD. News 1077, 1354.

$312 \S 206(\mathrm{~g})(3)(\mathrm{C}), 42$ U.S.C. $\$ 7525(\mathrm{~g})(3)(\mathrm{C})$ (Supp. I 1977).

30342 U.S.C. $\S 7525(\mathrm{~g})(3)(\mathrm{D})$ (Supp. I 1977).

sw Id. § 7525(g)(3)(E).

${ }^{315}$ H.R. Rep. No. 564, 95th Cong., 1st Sess. 163 (1977), reprinted in [1977] U.S. Cone Cong. \& AD. News 1502, 1544.

336 A formula for assessing penalties is to be promulgated by "regulations" after "notice and opportunity for a legislative [see toxt at notes 173-177 supra] public hearing," $\S 206(\mathrm{~g})$ (1), 42 U.S.C. $\$ 7525(\mathrm{~g})(1)$ (Supp. I 1977), but the formula must be applied to the facts of the particular case.

${ }^{317} \S 206(\mathrm{~b})(2)(B)(1), 42$ U.S.C. $\S 7525(b)(2)(B)(1)$ (Supp. I 1977). 
dures of the APA. ${ }^{398}$ For reasons given above, ${ }^{399} \mathrm{I}$ think due process requires the same procedures for the penalty determination, to the extent that adjudicative facts are in dispute.

The relationship between the nonconformance penalty provision of section $206(\mathrm{~g})$ and the authority to revise the ultimate heavyduty standards under section $202(a)(3)(B)^{400}$ is somewhat hazy. The basis of nonconforming certification is inability to meet the standard; yet the Administrator is authorized by section 202 to revise the standard itself, on what appears to be the same basis, so as to obviate the imposition of penalties. One way to accommodate the two provisions is to emphasize the presumptively permissive word "may" in the provision for revising the standard as giving the Administrator either a free choice between the alternatives, or power to adopt additional conditions, such as good faith efforts, for exercise of the revision authority.

The House Report, however, seems to suggest a different interpretation. Not only does it speak of penalties in the context of the gap between the "laggard" and the "technological leader," 401 but it does so in connection with the possible unfairness of a last-minute decision to revise the standards: revised standards are to be set on the basis of the leader's capability, but within limits, "[a]ny vehicle or engine which fails to meet the revised standards" may be certified, subject to penalty. ${ }^{402}$ Thus, as the EPA has concluded, ${ }^{403}$ it appears that nonconforming certification was viewed only as an answer to discrepancies between the capabilities of various manufacturers; revision is the appropriate remedy whenever no one can meet the statutory standard, although the policy against giving a free pass to sluggards, which underlies the penalty provision, is as applicable to the whole industry as to the individual maker.

${ }^{398}$ See 5 U.S.C. $\$ 554(a)(1976)$. The regulations provide an adjudicative hearing on denial of an application for certification as well. 40 C.F.R. $\$ 86.077-6,-22$ (c) (1978).

${ }^{389}$ See text and notes at notes 208-218 supra.

100 See text and notes at notes 250-258 supra.

101 H.R. REP. No. 294, 95th Cong., 1st Sess. 275 (1977), reprinted in [1977] U.S. CoDE Cong. \& AD. NEws 1077, 1354. See also § 206(g)(3)(E), 42 U.S.C. $\S 7525(\mathrm{~g})(3)$ (E) (Supp. I 1977). This section makes one factor in the setting of penalties the removal of "any competitive disadvantage to manufacturers whose engines or vehicles achieve the required degree of emission reduction" but does not necessarily imply there will be such manufacturers in all cases.

${ }^{102}$ H.R. Rep. No. 294, 95th Cong., 1st Sess. 275 (1977), reprinted in [1977] U.S. CoDE Cong. \& AD. News at 1354 (emphasis added). See also H.R. REP. No. 564, 95th Cong., 1st Sess. 162-63 (1977), reprinted in [1977] U.S. Code Cong. \& AD. News 1502, 1543 ("[a] vehicle or engine failing to meet the revised standards") (emphasis added).

${ }^{103} 44$ Fed. Reg. 9464, 9470 (1979). 


\section{G. Government Purchasing}

One interesting provision of the statute attempts to commit the immense purchasing power of the federal government to create an additional incentive for the development of better technology. Once the EPA has certified "low-emission vehicles" emitting pollutants "in amounts significantly below" applicable standards, ${ }^{404}$ the government must buy them "in lieu of other vehicles" if their costs are not more than $150 \%$ of those of the "least expensive" models "for which they are certified substitutes." 405 The Administrator has adopted regulations to implement this authority. ${ }^{406}$ Yet as late as 1977 one commentator, citing a government study, described it as "a model of imaginative draftsmanship and a virtual administrative dead letter, . . . a splendid idea which has not worked." "\$07

\section{H. Preemption}

In 1967, largely to protect the manufacturer from having to build engines to comply with a multiplicity of standards, ${ }^{408}$ Congress made a significant exception ${ }^{409}$ to the general principle, now found in section $116,{ }^{410}$ that the Clean Air Act does not preempt any state or local "requirement respecting control or abatement of air pollution." Under present section 209(a), "[n]o State or any political subdivision thereof shall adopt or attempt to enforce any standard relating to the control of emissions from new motor vehicles or new motor vehicle engines subject to this part."4II The Administrator was allowed to waive preemption only for California ${ }^{412}$ because of that State's unique experience and need; such a waiver also creates a testing ground for new regulations without subjecting industry to more than two regulations. ${ }^{413}$

The District of Columbia Circuit, however, has soundly concluded that the waiver of federal preemption for California does not

us $\S 212(\mathrm{a})(4)(\mathrm{A}),(\mathrm{d}), 42$ U.S.C. $\$ 7546(\mathrm{a})(4)(\mathrm{A})$, (d) (Supp. I 1977).

4os $\$$ 212(e)(1), 42 U.S.C. $\$ 7546(e)(1)$ (Supp. I 1977). The Certification Board established by section 7546 (b) may raise the figure to $200 \%$ under section $7546(\mathrm{e})(2)$ if the vehicle "is powered by an inherently low-polluting propulsion system."

ton 40 C.F.R. $\$ \S 85.1601-.1610$ (1978).

107 W. RoDGERs, supra note $36, \S 3.2$, at 219 (1977).

10s See S. REP. No. 403, 90th Cong., 1st Sess. 33 (1967).

47 Clean Air Act Amendments of 1967, Pub. L. No. 90-184, \& 2, 81 Stat. 501 (amending

Clean Air Act $\$ 208(a)$ ) (current version at 42 U.S.C. $\$ 7543(a)$ (Supp. I 1977)).

II 42 U.S.C. $\$ 7416$ (Supp. I 1977).

III Id. § 7543(a).

$112 I d$. $\S 7543$ (b) (allowing waiver only for states that adopted emission standards prior to March 30, 1966).

${ }^{13}$ See S. Rep. No. 403, 90th Cong., 1st Sess. 33 (1967). 
preclude the imposition of federal sanctions in the state: "The decision not to pre-empt simply allows both federal and state authorities to regulate emission controls." 414

I have discussed the scope of preemption under section 209(a) in detail in another article. ${ }^{415}$ Suffice it to note here that section 209(d) expressly provides that the statute does not preempt "the right otherwise to control, regulate, or restrict the use, operation, or movement of registered or licensed motor vehicles." 416 Further, the 1977 amendments allow any state to adopt approved California standards where necessary to achieve federally mandated levels of air quality. ${ }^{417}$

\section{Fuel Regulation}

Recognizing that what comes out of an engine may be influenced by what goes into it, ${ }^{418}$ Congress, as early as 1967 , authorized HEW to require registration of fuels as a condition to their introduction into commerce. ${ }^{419}$ The 1970 amendments extended coverage to fuel additives, authorized the EPA to require manufacturers to test fuels and additives, and added real teeth by giving the Administrator power, "by regulation," to "control or prohibit the manufacture,

\$14 United States v. Chrysler Corp., 591 F.2d 958, 961 (D.C. Cir. 1979). Similarly, the same court has unanswerably held that vehicles meeting California standards (which no longer need to be as strict as the federal in every respect) may be sold nationwide only if they meet federal standards as well, for the statute provides that "compliance with such State standards shall be treated as compliance with applicable Federal standards" only "in the case of any new motor vehicle ... to which State standards apply pursuant to a waiver," $\$$ 209(b)(3), 42 U.S.C. $\$ 7543$ (b)(3) (Supp. I 1977), and state standards apply only to vehicles "introduced for sale in California" or in other states referred to in the new provision cited in note 417 infra. Ford Motor Co, v. EPA, 606 F.2d 1293, 1300 \& n.54 (D.C. Cir. 1979).

More questionable was the holding in American Motors Corp. v. Blum, 603 F.2d 978 (D.C. Cir. 1979), that California may not impose an earlier $\mathrm{NO}_{\mathrm{x}}$ compliance date than the federal on small manufacturers dependent upon others for the development of control technology: California may not "deny to a small manufacturer the lead time that Congress has found to be necessary." Id. at 1415 . One might as persuasively argue that Congress found each statutory postponement of emission deadlines to be "necessary" to avoid an industry shutdown, yet California was given explicit permission to adopt stricter standards.

For two other decisions construing the California waiver provision, see Motor \& Equip. Mfrs. Ass'n v. EPA, 13 Envir. Rep. Cas. 1737, 1762 (D.C. Cir. 1979).

is Currie, Motor Vehicle Air Pollution: State Authority and Federal Pre-Emption, 68 MrCH. L. REv. 1083 (1970).

“t 42 U.S.C. $\$ 7543$ (d) (Supp. I 1977).

417 177, 42 U.S.C. $\$ 7507$ (Supp. I 1977).

118 See H.R. REP. No. 728, 90th Cong., 1st Sess. 23 (1967), reprinted in [1967] U.S. CoDE Cong. \& AD. News 1938, 1958-59.

119 Air Quality Control Act of 1967, Pub. L. 90-148, § 2, 81 Stat. 502 (amending Clean Air Act $\S 211$ ) (current version at 42 U.S.C. $\$ 7545$ (Supp. I 1977)). 
introduction into commerce, offering for sale, or sale of any fuel or fuel additive for use in a motor vehicle or motor vehicle engine." These provisions, as further amended in 1977, appear in section 211.421

\section{A. Registration}

Once the Administrator "by regulation"422 has "designate[d]" a fuel or additive, under section 211(a), "no manufacturer or processor . . . may sell, offer for sale, or introduce into commerce such fuel or additive" after the date prescribed by regulation, "unless the Administrator has registered . . . it in accordance with subsection (b)." ${ }^{23}$ Subsection (b), in turn, provides that the Administrator "shall" require submission of information as to the "chemical composition" of any additive, the identity of its manufacturer, and its "concentration" in fuel;"424 "may" require the manufacturer to conduct tests and provide a broad range of additional information; ${ }^{425}$ and "shall" register the fuel or additive upon compliance with the above requirements, "including assurances that the Administrator will receive changes in the information required." 426 Registration is thus dependent solely upon submission of information, not upon any demonstration that use of the fuel or additive is compatible with public health and welfare. Registration serves only to call potential problems to the EPA's attention.

"Not until November 1975," lamented the 1977 House Report, "did the Agency promulgate regulations to implement the registration program . . . ." 427 But by January 1977, 1,920 fuel additives, 511 motor-vehicle gasolines, and 250 vehicle diesel fuels had been registered..$^{428}$

The regulations in force in 1977 designated for registration

120 Clean Air Act Amendments of 1970, Pub. L. No. 91-604, § 9, 84 Stat. 1698 (amending Clean Air Act $\S 211(c)(1)$ ) (current version at 42 U.S.C. $\S 7545(c)(1)$ (Supp. 1 1977)).

42142 U.S.C. \& 7545 (Supp. I 1977).

122 Since 1977 "any regulation pertaining to any fuel or fuel additive under section [211]" is subject to the procedural requirements of section $307(d)$. Id. $\S 7606(d)(1)(D)$.

123 Id. \$7545(a).

${ }^{424}$ Id. $\$ 7545(\mathrm{~b})(1)(\mathrm{A})-(\mathrm{B})$.

425 Id. \& 7545(b)(2)(A)-(B).

12\% Id. \& 7545(b)(3).

${ }^{277}$ H.R. ReP. No. 294, 95th Cong., 1st Sess. 306-07 (1977), reprinted in [1977] U.S. CoDE Cong. \& AD. NEws 1077, 1385-86. The regulations appear at 40 C.F.R. $\S \S 79.1-.33$ (1978) (originally 40 Fed. Reg. 42,011 (1975)).

${ }^{123}$ H.R. REP. No. 294, 95th Cong., 1st Sess. 307 (1977), reprinted in [1977] U.S. CodE Cong. \& AD. News at 1386 (quoting a letter from the Acting Administrator). 
"motor vehicle gasoline," 429 "motor vehicle diesel fuel," "[a]ll additives produced or sold for use in motor vehicle gasoline, motor vehicle diesel fuel, and/or motor vehicle engine oil." 431 Additives and gasolines "specifically manufactured and marketed for motorcycles were excluded,"432 and "any designated fuel" (or additive) employed for "research, development, or test" purposes (or, in the case of fuel, for "factory fill"), was "exempt from registration." 433

Several interesting questions are suggested by these provisions. First, it is not surprising that all the substances designated by the EPA are used in "motor vehicles" as defined by the Act, since the regulatory action to which registration is a prelude is expressly limited to motor-vehicle fuel ${ }^{434}$ and since motor vehicles are the focus of the other sections in the same part of the statute. Nevertheless, the limiting words "motor vehicle" do not appear in section 211(a), which refers to "any fuel or fuel additive," and those terms are nowhere defined in the statute. The original 1967 provision, indeed, explicitly allowed designation of "fuels used for purposes other than motor vehicles." 435 The only relevant statement I have found in the legislative history suggests that the broad language of the 1967 provision was omitted as redundant rather than as undesirable. In explaining the conference bill, Senator Muskie declared in a printed appendix that section 211's authority to control or prohibit "motor vehicle fuels or additives" was "combined with added informationgathering powers in the registration of all fuels and fuel additives." ${ }^{338}$ Despite its apparent power to regulate all fuels, however, the EPA has not attempted to expand registration to fuels used in

42940 C.F.R. $\$ 79.32$ (1978).

${ }^{430}$ Id. $\$ 79.33$.

43140 Fed. Reg. 52,013 (1975).

13240 C.F.R. $\$ \S 79.31$ (a)-.32(a) (1978).

${ }^{43}$ Id. $\$ 79.4(\mathrm{a})$ (3) (fuel), (b) (2) (additive). The Act does not authorize the Administrator in terms to "exempt" any "designated" substance from registration, so that once any fuel is designated it technically must be registered. Yet he has by regulation exempted fuels or additives used only for research. The difficulty here is purely semantic, however; if a court should be so technical as to set the exemption aside, the defect could be remedied by rephrasing the research exemption as a limitation on the designated fuels or additives.

43 § 211(c)(1), 42 U.S.C. § 7545(c)(1) (Supp. I 1977).

${ }^{435}$ Air Quality Act of 1967, Pub. L. No. 90-148, $\S 2,81$ Stat. 502 (amending Clean Air Act $\$ 210(a)$ ) (current version at 42 U.S.C. $\$ 7525$ (a) (Supp. I 1977)). See H.R. REP. No. 728, 90th Cong., 1st Sess. 23 (1967), reprinted in [1967] U.S. Code Cong. \& AD. News 1938, 195859.

${ }^{136} 116$ CONG. REC. 42,383 (1970). The Senate Report spoke only of vehicle fuels, S. REP. No. 1196, 91st Cong., 2d Sess. 33 (1970), but the Senate bill, unlike the final product, was expressly limited to vehicle fuels, $i d$. at 116. 
aircraft, in vessels, in farm or construction equipment, or in stationary sources, though obviously a case could be made that it is important that the EPA know of any risks such fuels may entail.

The most interesting question raised by the Administrator's original designations is the inclusion of additives for use in "motor vehicle engine oil." The EPA regulations had expansively defined "fuel" as "any material which is capable of releasing energy or power by combustion or other chemical or physical reaction," ${ }^{437}$ but industry thought this excessive: "My shirt is capable of [meeting the definition], but most people do not regard it as a "fuel." " ${ }_{438}$ The EPA then fell back on the more reasonable argument that motor oil reaching the combustion chambers can result in harmful emissions, which it was the purpose of section 211 to prevent. ${ }^{439}$

In Lubrizol Corp. v. EPA, ${ }^{40}$ the Court of Appeals for the District of Columbia Circuit held the motor-oil provision invalid. First, the argument that the EPA could regulate "any potential contributor to emissions . . . known to Congress in 1970 . . . would allow it to regulate the design of . . . engines . . . as well as methods of auto maintenance and driving techniques," which obviously are not "fuels." 441 This passage is unconvincing: motor oil, unlike engine design, is arguably a "fuel" since some of it actually is burned in the engine. But the court was quite persuasive in its further argument: in light of the "marked tendency of the legislators debating the provision to use 'fuel' and 'gasoline' interchangeably," 442 there was no reason to think Congress meant to depart from the "common sense understanding of the word 'fuel' as the substances used to propel motor vehicles." 443

43740 C.F.R. $\$ 79.2(c)(1978)$.

138 Letter from Lewis Green to T.P. Sands (Apr. 16, 1974), quoted in Lubrizol Corp. v. EPA, 562 F.2d 807, 811 n.13 (D.C. Cir. 1977).

13) See Lubrizol Corp. v. EPA, 562 F.2d 807, 816 (D.C. Cir. 1977).

416 562 F.2d 807 (D.C. Cir. 1977).

111 Id. at 818 .

12 Id.

"s Id. at 816 (emphasis in original). Not cited by the court, however, was the Supreme Court's contrary split decision, in the analogous case of United States v. Standard Oil Co., 384 U.S. 224 (1966), that valuable gasoline spilled into the water was "refuse" within the Rivers and Harbors Appropriation Act of 1899. The Court observed that since gasoline, "whether usable or not by industrial standards . . . has the same deleterious effect on waterways," id. at 226, "refuse" includes " 'anything which has become waste" " by reaching the water, id. at 229 (quoting United States v. Ballard Oil Co., 195 F.2d 369, 371 (2d Cir. 1952)). If gasoline unintentionally discarded is "refuse," the same reasoning may lead to the conclusion that lubricating oil incidentally burned is "fuel."

Perhaps it is not inconsistent to read "refuse" from the viewpoint of its impact and "fuel" from that of the actor's intention, but the analogy is a close one. A less subjective basis for 
The 1977 amendments did not address the problem of engine oil; the Lubrizol opinion was delivered a few days after they were enacted. The 1977 House Report expressed a clear opinion on how the 1970 amendments should be interpreted:

[T] additives" intended that these terms be construed broadly, as with existing section 211 , to include any substance that is intentionally put into a vehicle's motor, either directly or indirectly, and which is combusted in the engine. In terms of the potential effect on pollution control devices or on public health, it matters not whether any such substance makes its way from the engine to the gas tank [sic] or is put directly into the engine. ${ }^{444}$

The meaning a legislative committee attributes to words it has drafted is entitled to considerable respect, but that which it attaches to pre-existing law is another story. If Lubrizol was right that the 1970 reference to "fuel" excluded motor oil, the 1977 Committee's disagreement is only an opinion to the contrary. ${ }^{445}$ Nevertheless the EPA, after repealing its existing reference to motor-oil additives in response to the Lubrizol mandate, ${ }^{446}$ has announced its expectation to reinstate it in reliance on the Committee's opinion..$^{447}$

\section{B. Testing}

Since 1970, section 211(b)(2)(A) had authorized the EPA to require manufacturers to test fuels or additives "to determine potential public health effects." 448 But in 1977 the House Committee complained that "the Agency did not even begin to work on testing requirements until January 25, 1977." ${ }_{449}$ Even then the Agency's

possible distinction is the absence from the fuel provisions of exemplary terms such as "ashes" and "acids," which the Court in Standard Oil seized on because they were included as "refuse" "whether or not they had any remaining commercial or industrial value." 384 U.S. at 228 .

"' H.R. ReP. No. 294, 95th Cong., 1st Sess. 309 (1977), reprinted in [1977] U.S. CoDE CoNG. \& AD. News 1077, 1388.

"45 See Regional Rail Reorganization Act Cases, 419 U.S. 102, 132 (1974) ("[P]ostpassage remarks of legislators, however explicit, cannot serve to change the legislative intent of Congress expressed before the Act's passage.").

44t See 43 Fed. Reg. 28,489-90 (1978). See also id. at 38,607.

" 4 See id. at $28,489-90$.

4842 U.S.C. $\$ 7545(\mathrm{~b})(2)$ (A) (Supp. I 1977).

t19 H.R. REP. No. 294, 95th Cong., 1st Sess. 307 (1977), reprinted in [1977] U.S. CodE CoNG. \& AD. NEws 1077, 1386. The regulations stated only that "the Administrator may establish procedures and protocols for the conduct of tests . . . and may thereafter require a 
plan was to rely on its own research to identify potentially troublesome candidates for selective testing by the manufacturer. ${ }^{450}$ The Committee found this "wholly unsatisfactory": the Agency's proposed approach "requires it to prove a fuel or fuel additive probably harmful, before the manufacturer would be required to test it."

Impatient, Congress in 1977 enacted a new section 211(e), which required the Administrator within one year, after "notice and opportunity for public hearing," 452 to "promulgate regulations which implement the authority under subsection (b)(2)(A) and (B) of this section with respect to each fuel or fuel additive which is registered ... [or] for which an application for registration is filed" in the future..$^{43}$ In other words, with minor exceptions provided in section $211(e)(3),{ }^{454}$ he must require manufacturers to test every designated fuel or additive. ${ }^{455}$ Compliance promises to be a considerable burden, since over 2,600 fuels and additives had been registered by 1977.458

\section{Controls and Prohibitions}

Congress had two reasons for concern about fuel composition: that additives might pass through vehicles and directly endanger the public, and that they might adversely affect devices to control other automotive emissions. ${ }^{457}$ Accordingly the 1970 statute, in section 211(c), authorized the EPA to "control or prohibit" fuels or additives on alternative grounds:

(A) if any emission products of such fuel or fuel additive will endanger the public health or welfare, or (B) if emission products of such fuel or fuel additive will impair to a significant degree the performance of any emission control device or sys-

. . manufacturer . . . to conduct tests." 40 C.F.R. $\S 79.6$ (1978). This added nothing to the statute.

tso H.R. REP. No. 294, 95th Cong., 1st Sess. 307 (quoting letter from Acting Administrator John R. Quarles to Rep. Paul G. Rogers (Feb. 28, 1977)), reprinted in [1977] U.S. CoDE Cong. \& AD. NEws at 1386.

${ }^{131}$ Id. at 307, reprinted in [1977] U.S. Code Cong. \& AD. NEws at 1386.

${ }^{152} 42$ U.S.C. $\$ 7545$ (e) (Supp. I 1977). The hearing is subject to the procedures prescribed by section $307(d)(1)(D), 42$ U.S.C. $\$ 7607$ (d)(1)(D) (Supp. I 1977).

${ }^{153}$ Id. $\S 7545(\mathrm{e})(1)$.

ist Id. § 7545(e)(3) (allowing the EPA to exempt "any small business," to "provide for cost sharing" by common manufacturers, and to avoid "duplicative" testing).

iss See H.R. REP. No. 294, 95th Cong., 1st Sess. 308 (1977), reprinted in [1977] U.S. Code CoNG. \& AD. NEws 1077, 1387. He must also require manufacturers to provide additional information, as the regulations already provided. E.g., 40 C.F.R. $\S 79.31$ (c)-(d) (1978).

tst H.R. REP. No. 294, 95th Cong., 1st Sess. 308 (1977), reprinted in [1977] U.S. CoDE CoNG. \& AD. NEws at 1387.

${ }^{157}$ S. REP. No. 1196, 91st Cong., 2d Sess. 33-34 (1970). 
tem which is in general use, or which the Administrator finds has been developed to a point where in a reasonable time it would be in general use were such regulation to be promulgated. ${ }^{458}$

Before promulgating a health standard under clause (A), the Administrator is to consider "all relevant medical and scientific evidence available," including that relating to "other technologically or economically feasible means of achieving emission standards under section [202]." 459 Before promulgating a standard to protect emission-control technology under clause (B), he is to consider "available scientific and economic data, including a cost benefit analysis comparing emission control devices or systems which are or will be in general use and require the proposed control or prohibition" with those not requiring it. ${ }^{460}$ Upon request by a manufacturer, the EPA is to hold "a public hearing" and to "publish findings with respect to any matter the Administrator is required to consider," apparently only in promulgating a standard under clause (B)..$^{461}$ Before acting under either clause, the Administrator must find in writing "that in his judgment such prohibition will not cause the use of any other fuel or fuel additive which will produce emissions which will endanger the public health or welfare to the same or greater degree than the use of the fuel or fuel additive proposed to be prohibited." 462 As in the case of all regulations "pertaining to any fuel or fuel additive under section [211]," the rulemaking procedures of section $307(d)$ must be followed. ${ }^{463}$

1. Standards to Protect Control Devices. The Senate Committee had noted that lead "can reduce the effectiveness of . . . catalytic mufflers by up to 90 percent." 464 In January 1973, the EPA adopted regulations under section $211(\mathrm{c})(1)(B)$ limiting the lead

15s Clean Air Act Amendments of 1970, Pub. L. No. 91-604, § 9(a), 84 Stat. 1698 (amending Clean Air Act $\$ 211$ (c)(1) (current version at 42 U.S.C. $\$ 7545(c)(1)$ (Supp. I 1977)).

15) 42 U.S.C. $\$ 7545$ (c)(2)(A) (Supp. I 1977).

${ }^{460} I d . \S 7545(\mathrm{c})(2)(\mathrm{B})$.

4II Id. Section 211(c)(2)(B) also specifies a hearing and findings as to matters the EPA "is required to consider under this subparagraph." Elsewhere section $211(\mathrm{c})(1)$, which authorizes both health and control-device standards, is described as a "paragraph," suggesting the "subparagraph" reference is to clause (B) of "paragraph" (2), and clause (B) requires consideration of "matters" only in connection with control-device standards. See Ethyl Corp. v. EPA, 541 F.2d 1, 34 n.69 (D.C. Cir.) (en banc) (declaring the hearing requirement inapplicable to health regulations under section 211(c)(1)(A)), cert. denied, 426 U.S. 941 (1976).

${ }^{162} \& 211(\mathrm{c})(2)(\mathrm{C}), 42$ U.S.C. $\& 7545(\mathrm{c})(2)(\mathrm{C})$ (Supp. I 1977).

40342 U.S.C. $\$ 7607(\mathrm{~d})(1)(\mathrm{D})$ (Supp. I 1977).

tt S. REP. No. 1196, 91st Cong., 1st Sess. 34 (1977). 
content of gasoline in order to prevent such damage. ${ }^{465}$ It was made illegal for any retailer or wholesale consumer ${ }^{466}$ to introduce "leaded" gasoline (defined as including more than 0.05 grams of lead or 0.005 grams of phosphorus per gallon) ${ }^{467}$ into cars marked or designed for exclusive use of unleaded fuel. ${ }^{468}$ Manufacturers of new cars whose emission controls would be damaged by lead were required to affix to them permanent labels reading "unleaded gasoline only" and to provide them with gas tanks with small inlet holes. ${ }^{469}$ Gasoline retailers and wholesale consumers were required to dispense leaded fuels from nozzles too big to fit into such cars, ${ }^{470}$ and large retailers were required to offer unleaded gasoline after July 1 , 1974. ${ }^{471}$

The inevitable judicial challenge was essentially rejected by the District of Columbia Circuit in Amoco Oil Co. v. EPA. ${ }^{472}$ The court after considerable discussion held the statutorily required findings adequate, ${ }^{473}$ and found ample support for the EPA's conclusions that an $0.05 \mathrm{gram} / \mathrm{gallon}$ standard was both necessary and feasible. ${ }^{474}$

The most interesting argument was that the requirement that retailers offer unleaded gasoline was not authorized by the statutory power to control or prohibit the manufacture or sale of damaging fuels. To this "narrow, linguistic argument" the court offered a

tw 38 Fed. Reg. 1254 (1973) (codified in 40 C.F.R. $\$ 80$ (1978)).

"' A wholesale consumer is numerically defined as one having a storage tank of at least 550 gallons, 40 C.F.R. $\$ 80.2(0)$ (1978).

"tw Id. \& 80.2(f).

tes Id. $\$ 80.22(\mathrm{a})$.

4s Id. $\$ 80.24$. Enlargement of the inlet hole would appear to be covered by the antitampering provisions of section 203(a), see text at notes 361-370 supra. The provisions forbid professionals (but not the owner himself) to "remove or render inoperative any device or element of design installed on or in a motor vehicle in compliance with regulations under this part," and the fuel provisions are found in the same Part A of Title II as is section 203(a).

47040 C.F.R. $\$ 80.22(f)(1978)$.

47I Id. $\$ 80.22(\mathrm{~b})$.

472501 F.2d 722 (D.C. Cir. 1974).

${ }^{473} \mathrm{Id}$. at 731-41. The opinion contains a detailed and practical interpretation of the findings provisions. In particular, section $211(\mathrm{c})(2)(B)$ was read to require only a finding " that the [vehicle] emission standards . . . cannot be achieved in acceptable fashion by relying on ... devices in 'general use' which "do not require the proposed control or prohibition." Id. at 736.

${ }^{474}$ Id. at 741-43. The statute does not require that compliance be "feasible" or economically reasonable, but it does not preclude adoption of regulations that consider these factors. The court also found wanting a challenge based on the National Environmental Policy Act of 1969, 42 U.S.C. $\$ \S 4321-4347$ (1976). 501 F.2d at 749-50. The Clean Air Act is now expressly exempt from NEPA requirements. Energy Supply and Environmental Coordination Act of 1974, Pub. L. No. 93-319, § 7(c)(1), 88 Stat. 259 (current version at 15 U.S.C. $\S 793(c)(1)$ (Supp. I 1977)). 
"similarly narrow and linguistic answer": "The affirmative marketing requirement does in fact 'control' the sale of leaded gasoline, for the regulation provides in effect that the specified retailers may sell no leaded gasoline unless and until they also offer for sale one grade of unleaded gasoline." 475 The court underscored the necessity for the requirement: "If unleaded gasoline is not conveniently available for these vehicles, the new car market may well collapse, the phasingin of converter technology will be paralyzed, and the Clean Air Act's schedule for reducing air pollution will be severely compromised." ${ }_{476}$ Not challenged were the restrictions on automobile manufacturers, which one suspects the court would similarly have found necessary to "control" the "sale" of leaded gasoline.

The EPA's regulations extended liability for introducing leaded gasoline into the wrong car from a pump normally used for unleaded fuel $^{477}$ to distributors ${ }^{478}$ and sometimes to refiners, ${ }^{479}$ since it was conceded that "lead contamination . . . is typically caused in the pre-retail stages" and that "it would be extremely difficult for the Agency to locate the source of contamination in each instance." 480 The court, however, accepted the objection that the distributor must be allowed to escape liability by showing "that its employees and agents did not cause the contamination," and the refiner by showing that its "employees, agents, or lessees" were not responsible and "that the contamination could not have been prevented by a reasonable program of contractual oversight." 481 Redrafted in strict conformity to the opinion of the court of appeals, ${ }^{482}$ the vicarious liability provision was nevertheless struck down again: a blanket responsibility of refiners for negligent acts of their lessees went "well beyond the bounds of traditional vicarious liability" and thus exceeded the authority given by section 211.483 Judge Wright dissented on both obvious grounds: that common-law precedents do not control the interpretation of the statute, and that the issue had been determined in the earlier decision. ${ }^{484}$

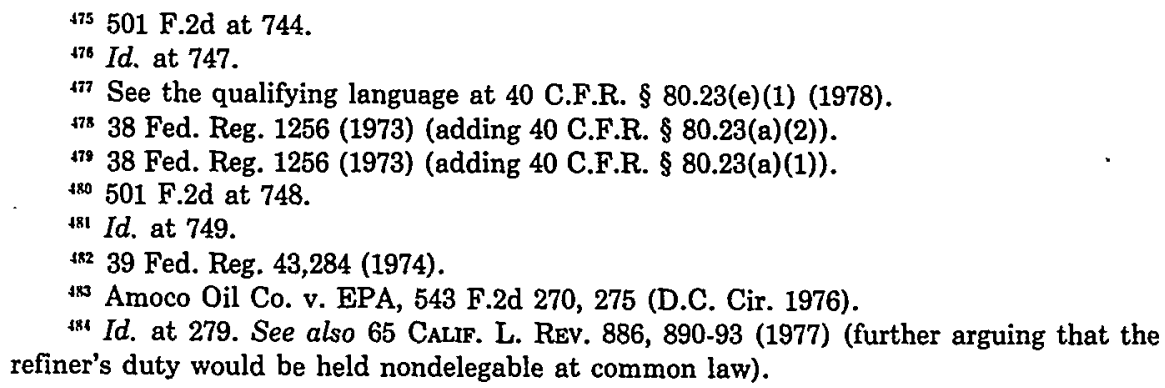

181 Id. at 279. See also 65 CALIF. L. REv. 886, 890-93 (1977) (further arguing that the refiner's duty would be held nondelegable at common law). 
2. Standards to Protect Health and Welfare. In December 1973, in order to reduce the health hazard from lead emissions, the EPA under section 211(e)(1)(A) adopted a further regulation requiring a progressive reduction in the average lead content of all gasolines to 0.5 grams per gallon by January $1979 .{ }^{485}$ This regulation was initially set aside by a divided panel of the District of Columbia Circuit in Ethyl Corp. v. EPA. ${ }^{486}$ The opinion has considerable significance for the regulation of pollution risks generally in the absence of complete knowledge.

The 1970 amendments allowed regulation under the health provision only if emissions resulting from use of the fuel or additive "will endanger the public health or welfare." 487 The panel conceded that Congress had not required a determination that airborne lead would itself endanger health "without considering other sources of lead in the human body." 488 Moreover, while disparaging the dissent's attempted distinction between "actual" and "potential" harm, ${ }^{489}$ the court may have left some room for prediction of health effects by paraphrasing the statutory "endanger[ment]" requirement as one of " $a$ significant health hazard." ${ }_{400}$

The panel based its decision on alternative grounds. First, the EPA had misconstrued the "will endanger" language, which "was intended by Congress to 'turn crucially on factual issues' and not upon "choices of policy." "491 Moreover, section 211(c)(1)(A) required a more exacting showing that harm would result than the vehicleemission provision of section 202(a) ${ }^{492}$ (any pollutant "which in his judgment cause[s] or contributes to, or is likely to cause or contribute to, air pollution which endangers the public health or welfare") or the air-quality-standard provision of section $108^{493}$ (any

4s 38 Fed. Reg. 13,741 (1973). The determination is to be made on the basis of the total amount of lead in all gasoline, whether leaded or not, produced by a refinery; leaded gasoline may thus contain more lead if a greater proportion of the total product is unleaded. See $\mathbf{4 0}$ C.F.R. $\$ 80.20$ (a)(2) (1978).

is 7 Envir. Rep. Cas. 1353 (D.C. Cir. 1975), rev'd on rehearing en banc, 541 F.2d 1 (D.C. Cir.), cert. denied, 426 U.S. 941 (1976).

187 Clean Air Act Amendments of 1970, Pub. L. No. 91-604, § 9(a), 84 Stat. 1698 (amending Clean Air Act $\S 211(c)(1)(A)$ ) (current version at 42 U.S.C. $\S 7545(c)(1)(A)$ (Supp. I 1977)).

ss 7 Envir. Rep. Cas. at 1357.

138 "[T] he best (and only convincing) proof of such potential harm is what has occurred in the past ...."Id.

100 Id. (emphasis in original).

17' Id. at 1361 (quoting Amoco Oil Co. v. EPA, 501 F.2d 722, 740-41 (D.C. Cir. 1974)).

12 Clean Air Act Amendments of 1970, Pub. L. No. 91-604, §6(a), 84 Stat. 1690 (amending Clean Air Act $\S 202(a)$ ) (current version at 42 U.S.C. $\S 7521$ (a) (Supp. I 1977)).

'33 Id. $\S 4(\mathrm{a}), 84$ Stat. 1678 (amending Clean Air Act $\S 108(\mathrm{a})(1)(\mathrm{A})$ ) (current version at 
pollutant "which in his judgment has an adverse effect on public health or welfare"). ${ }^{494}$ In sum, the court said that section 211(c) (1)(A) required a threshold determination "that an identifiable measurable increment of lead in the human body is derived from auto fuel additives and that this measurable increment of lead itself (taking into consideration all other sources of lead) causes a significant health hazard." ${ }^{495}$ Finally, the panel held, the Administrator had acted arbitrarily in finding that lead from vehicles made a " 'significant contribution to elevated blood lead levels' in either the general population or among children."496

On rehearing en banc, the regulation was upheld..$^{47}$ Most significant was the court's ringing rejection of the idea that actual harm must precede regulation:

Case law and dictionary definition agree that endanger means something less than actual harm. . . . Regulatory action may be taken before the threatened harm occurs; indeed, the very existence of such precautionary legislation would seem to demand that regulatory action precede, and, optimally, prevent, the perceived threat. . . . Ethyl is correct that we have not had the opportunity to learn from the consequences of an environmental overdose of lead emissions; Congress, however, sought to spare us that communal experience by enacting $\S$ $211(\mathrm{c})(1)(\mathrm{A}) .^{498}$

Cited in support ${ }^{499}$ was the Eighth Circuit's celebrated decision in Reserve Mining Co. v. EPA. ${ }^{500}$ In that case, the court upheld a finding that asbestos discharges into Lake Superior "endanger[ed] the health . . . of persons" under the Federal Water Pollution Control Act $\mathrm{At}^{501}$ on the basis of a similar "precautionary or preventive" interpretation.

The air-quality-standard provision of section 108, which the

42 U.S.C. $\& 7408(a)(1)$ (A) (Supp. I 1977)).

" 7 Envir. Rep. Cas. at 1361-64.

${ }^{903}$ Id. at 1357 (emphasis in original).

136 Id. at 1376.

งn Ethyl Corp. v. EPA, 541 F.2d I (D.C. Cir.), cert. denied, 426 U.S. 941 (1976).

${ }^{483} I d$. at 13 (emphasis in original).

193 Id. at $13 \mathrm{n} .18$,

${ }_{500} 514$ F.2d 492, 528 (8th Cir. 1975), modified sub nom. Reserve Mining Co. v. Lord, 529 F.2d 181 (8th Cir. 1976).

s01 The court was construing what was then section 33 U.S.C. $\$ 1160$ (1970). That section was superseded by the Federal Water Pollution Control Act Amendments of 1972, Pub. L. No. 92-500, $\S 2,86$ Stat. 816 (current version codified in scattered sections of Title 33). 
panel had thought showed that section 211 , by contrast, imposed a particularly exacting requirement, was shown to reinforce the conclusion that section 211 was preventive: in contrast to section 211's "will endanger," section 108 "require[d] an actual 'adverse effect' on health." 502 While section 202's vehicle-emission provision appeared to give the EPA more leeway in that it employed the additional phrase "is likely to," " "[l]ikely' enters the equation only in determining whether the emitted air pollutant . . . contributes to the air pollution that is found dangerous. ... [I]n making the threshold determination of danger both sections are the same: air pollution must endanger the public health before regulation is justified." "503

One can only lament that such an extensive expatiation of the obvious was necessary.

The remainder of the Ethyl opinion, faithful to Congress's clear intention that the EPA anticipate and prevent future harm, reflects a broad deference to the Agency. Disapproved was the panel's insistence that danger be determined on a purely "factual" basis: a requirement of "specific findings" on the issue had been dropped in conference, and "how can [the Administrator] . . . assess risks if he cannot make policy judgments?"'504 The panel's conclusion that regulation was permissible if airborne and other sources created an aggregate lead danger was reaffirmed. ${ }^{005}$ The statute was once more paraphrased:

[T] he Administrator may regulate lead additives under Section $211(c)(1)(A)$ when he determines, based on his assessment of risks as developed by consideration of all the evidence available to him, and guided by the policy judgment inherent in the statute, that lead automobile emissions significantly increase the total human exposure to lead so as to cause a significant risk of harm to the public health. ${ }^{506}$

so2 541 F.2d at 14.

${ }^{\text {sas }} \mathrm{Id}$. at 16. I am not so confident as was the court that the word "likely" in section 202 had no relation to the dangerousness of the predicted pollution, but the point is immaterial; that Congress may have chosen to be redundant in one provision of a most complicated statute cannot destroy the clear cautionary import of the word "endanger" in an essentially unrelated provision.

sor Id. at 20-29.

sos "Id. at 29-31.

5oi Id. at 31-32. The decision not to regulate lead emissions under section 202 was found sustainable because section 202 was limited to emissions from new vehicles. Id. at 32 n.66. The court stressed the deletion of a requirement of a finding that section 202 regulation was impracticable: "While Congress thus indicated its preference for regulation under section 202, 
The opinion then devoted detailed attention to the evidentiary basis of the Agency's central conclusion that fuel lead endangered public health. Basic once more was the deduction drawn from Congress's preventive intention: "the Administrator's decision may be fully supportable if it is based, as it is, on the inconclusive but suggested results of numerous studies." 507 The essential message is a justified repudiation of the premise of the panel opinion: to insist upon certainty at any step of the Agency's reasoning is inconsistent with Congress's choice to prevent "danger," that is, the risk or threat of harm.

The court found little dispute that lead in sufficient quantities was poisonous, that lead in the air "contribute[d] to body blood lead levels," that ambient lead levels in some cities were "2,000 times greater" than those "over the mid-Pacific," and that $90 \%$ of lead in the air was attributable to vehicle emissions. ${ }^{508}$ The dispute, reduced to essentials, was whether the amounts of lead that could be expected to be added to the body by airborne lead created a risk that was significant.

Agreeing that 40 micrograms per 100 grams of blood was a reasonable "precautionary level" to be avoided,"09 the dissent argued, as had the panel, that there was no basis for finding that this level existed among "a significant portion of the general adult population" or that high lead levels in children could be attributed to airborne concentrations. ${ }^{510}$ The majority retorted that, among other things, the existence of excessive lead levels in occupational groups such as "policemen, mailmen, service station employees, parking lot attendants," and the like, "whose only exposure to lead is through the ambient air," was "indicative of high blood lead

it left the Administrator with full discretion to implement this preference or not." Id.

The finding that lead substitutes would not cause an equal danger was upheld because hydrocarbon-emission standards would produce an enormous improvement in the emissions from substitute fuels over the next few years. Id. at 33 n.68. The court also suggested, though it did not decide, that since section 211 (c)(2)(C) speaks only of a regulation that "prohibits" a fuel or additive and the lead regulations only "control" lead additives, the findings requirement might not apply. The court conceded that the purpose of the requirement was fully applicable; very likely, the omission was due to clerical oversight. Id. at 32 n.67. Moreover, the line between "control" and "prohibition" is not distinct: the regulation at issue prohibited the sale of fuel containing more than the specified lead concentration.

${ }^{307}$ Id. at $37-38$.

508 Id. at 38.

${ }^{508}$ Id. at 101-02 (Wilkey, J., dissenting). For justification, see the majority opinion, id. at $38-40$.

s10 See, e.g., id. at 103: "A sample of 55 'Women Living Near Freeways' uncovered one person at 40 ug [sic] or above"; another study of " 1,935 persons" found "only three"; even among Los Angeles cab drivers the average level was "a normal 24.6 ug [sic]." 
levels among a significant portion of the adult population";";n it would have made sense to adopt regulations even if they were the only ones threatened. ${ }^{512}$ The majority may have had to rely on this evidence to avoid a dilatory remand, for the Administrator had expressly declared that airborne lead "when added to lead from other sources . . . results in total exposure that is excessive," under SEC $v$. Chenery Corp., ${ }^{514}$ administrative action may not be sustained on a basis other than that relied on by the agency.

More fundamental for future regulation, however, was the court's clear declaration that future danger, rather than existing harm, is decisive: "the occupational data . . . suggest the future likelihood, absent controls, of increasing high blood levels among even more widely dispersed portions of the public." 515 In the confusing welter of facts, this observation seems most telling: the congressional insistence on prevention was not compatible with a requirement that vehicle emissions had already contributed to excessive lead levels in people..$^{516}$

Enthusiastically endorsing "the views expressed in the majority opinion of the en banc panel on rehearing" in Ethyl, ${ }^{517}$ the House Committee in 1977 reported, ${ }^{518}$ and Congress adopted, a new criterion to govern promulgation not only of fuel regulations ${ }^{519}$ but also of standards for air quality, ${ }^{520}$ new-source performance, ${ }^{521}$ hazardous emissions, ${ }^{522}$ vehicle emissions, ${ }^{523}$ and aircraft emissions. ${ }^{524}$ The fuel

si1 Id. at $40-41$.

si2 Id. at 40 n.89.

sis See id. at 114 (reprinting as appendix 38 Fed. Reg. 33,734-37 (1973)).

stu 318 U.S. 80, 94 (1943).

sis 541 F.2d at 41 .

sis It may be argued that the regulations previously adopted to protect emission-control devices will result in decreasing lead emissions and render any precaution against increasing ambient concentrations unnecessary. This position presupposes continued reliance on catalytic converters, which cannot safely be assumed.

The dissent made much of a procedural issue, arguing that there had been no adequate opportunity for comment on information on which the Administrator had significantly relied, id. at 78-94, and the majority attempted to respond, id. at 48-53. The principle invoked by the dissent was firmly established, see text and notes at notes 171-172, 227 supra; whether it was correctly applied in this case is not important to the substantive analysis in Ethyl, and I express no view on that question.

${ }^{517}$ H.R. REP. No. 294, 95th Cong., 1st Sess. 49 (1977), reprinted in [1977] U.S. CodE

Cong. \& AD. News 1077, 1127.

5ts See id. at 50, reprinted in [1977] U.S. Code Cong. \& AD. News at 1128.

511 $\$ 211$ (c)(1), 42 U.S.C. $\$ 7545$ (c)(1) (Supp. I 1977).

$520 \S 108(\mathrm{a})(1)(\mathrm{A}), 42$ U.S.C. $\$ 7408(\mathrm{a})(1)(\mathrm{A})$ (Supp. I 1977).

$321 \S 111(\mathrm{~b})(1)(\mathrm{A}), 42$ U.S.C. $\S 7411(\mathrm{~b})(1)(\mathrm{A})$ (Supp. I 1977).

s2 \& 112(a)(1), 42 U.S.C. \& 7412(a)(1) (Supp. I 1977).

s23 \& 202(a)(1), 42 U.S.C. $\$ 7521(a)(1)$ (Supp. I (1977).

$524 \S 231(\mathrm{a})(2), 42$ U.S.C. $\S 7571(\mathrm{a})(2)$ (Supp. I 1977). 
provision in section 211(c)(1)(A) now authorizes regulation "if in the judgment of the Administrator any emission product of such fuel or fuel additive causes . . . or contributes . . . to air pollution which may reasonably be anticipated to endanger the public health or welfare." 525 The three-judge panel in Ethyl had come close to saying that catastrophe must precede regulation. The en banc decision and the congressional response resoundingly interred that unacceptable notion.

The Ethyl litigation focused exclusively on the question whether health considerations justified any regulation of fuel lead at all; nothing was said about the justification for the particular ceiling on lead content the regulation imposed. Since the statute happily does not provide otherwise, the Administrator quite properly considered both the benefits and the costs of achieving the prescribed reduction, which he said was "designed to accomplish a 60-65 percent decrease in lead usage from base 1971"526 and which was predicted to "increase the cost of producing gasoline by less than .1c per gallon." "527

This cost, even multiplied by the huge number of gallons consumed, hardly seems excessive if it gives us reasonable insurance against widespread poisoning. What is less clear from the Administrator's explanation is why he concluded that a 60 to $65 \%$ reduction in 1971 emissions would do the job. Initially the EPA had proceeded on the assumption that an ambient lead level of 2 micrograms per cubic meter should be avoided in the interest of public health; an emission level could have been derived from such a goal by mathematical modeling. The Agency later determined, however, "that it was difficult, if not impossible, to establish a precise level of airborne lead as an acceptable basis for a control strategy." 528 This being so, one might have expected the enunciation of some alternative basis for the figures chosen, such as the limits of technology without prohibitive cost. ${ }^{529}$ Instead the explanation makes the figure appear to have been plucked at random. Unfortunately, a random standard is not the best safeguard against either lead poisoning or judicial review. . $^{330}$

${ }^{525} 42$ U.S.C. $\$ 7545$ (c)(1)(A) (Supp. I 1977).

${ }^{228} 38$ Fed. Reg. 33,740 (1973).

527 Id. at 33,739 .

${ }^{223} \mathrm{Id}$. at 33,734 .

520 The EPA has since concluded that the fuel standard should suffice in the foreseeable future to assure compliance with the subsequently adopted ambient lead standard of 1.5 $\mu \mathrm{g} / \mathrm{m}^{3}$ except where there are significant stationary sources. See 43 Fed. Reg. 46,246, 46,247 (1978).

530 The statute now prescribes more lenient lead standards for small refineries until 


\section{Preemption}

Section $211(c)(4)$, adopted in 1977, contains a preemption provision concerning fuel regulation significantly less onerous than that preventing states from implementing new-vehicle emission standards:

(A) Except as otherwise provided in subparagraph (B) or (C), no State (or political subdivision thereof) may prescribe or attempt to enforce, for purposes of motor vehicle emission control, any control or prohibition respecting use of a fuel or fuel additive in a motor vehicle or motor vehicle engine-

(i) if the Administrator has found that no control or prohibition under paragraph (1) is necessary and has published his finding in the Federal Register, or (ii) if the administrator has prescribed under paragraph (1) a control or prohibition applicable to such fuel or fuel additive, unless State prohibition or control is identical to the prohibition or control prescribed by the Administrator. ${ }^{531}$

The exceptions in subparagraphs (B) and (C) allow fuel regulation by California "at any time" 532 and by any other State in an implementation plan if "necessary to achieve" national ambient airquality standards. ${ }^{533}$

After the EPA had adopted fuel-lead standards to protect catalytic converters, ${ }^{534}$ but before it had adopted standards to protect against direct health effects of lead emissions, a federal trial court in Exxon Corp. v. City of New York ${ }^{535}$ upheld a New York City

October 1, 1982. § 211(g)(2), 42 U.S.C. $\$ 7545(\mathrm{~g})(2)$ (Supp. I 1977).

sal 42 U.S.C. $\$ 7545$ (c)(4)(A) (Supp. I 1977). The Administrator may refuse to regulate a fuel or additive not only on the ground that control is not "necessary" but on the ground that he lacks authority to do so. Since the limits on the EPA's authority reflect congressional policy that regulation under the specified circumstances (for example, no endangerment of health or welfare, worse emissions from substitute technology) is undesirable, "necessary" was an unfortunate word to choose. It should be construed as broadly as possible to reflect the policy against regulation that the federal government determines undesirable.

ssz The exceptions reach "any State for which application of section [209(a)] . . . has at any time been waived." Id. $\S 7545$ (c)(4)(B). Such waiver is authorized only for California, and it has been granted. The statute does not require a current waiver under section 209; once a waiver has been granted "at any time," California may regulate fuels "at any time." See H.R. REP. No. 1783, 91st Cong., 2d Sess. 53 (1970), reprinted in [1970] U.S. Code Cong. \& AD. News 5374, 5385: "These restrictions will not apply to California."

33342 U.S.C. \& 7545(c)(4)(C) (Supp. I 1977). The EPA construes this proviso to allow state fuel regulation only if "no other reasonable measures are available" for achieving the ambient standard. 43 Fed. Reg. 46,264, 46,266 (1978).

3343 Fed. Reg. 1254 (1978).

sss 356 F. Supp. 660 (S.D.N.Y. 1973), rev'd, 548 F.2d 1088 (2d Cir. 1977). 
ordinance limiting lead for the latter purpose against a claim of preemption: "The Federal Administrator has acted with regard for [protection of control devices] but has not as yet acted with regard to the health standard. Until he does, the City of New York is free to enact and enforce its own regulations." 536

The Second Circuit, reviewing this decision after the EPA had adopted health standards for lead ${ }^{537}$ but before the date those standards became applicable, reversed: reporting and monitoring provisions of the new health regulation, integral parts of the "phase-down timetable," were already in force. ${ }^{538}$ The court of appeals also struck down a local limit on the volatility of gasoline, though the federal regulations referred only to lead and phosphorus: "The City has added a control or prohibition applicable to the fuel of motor vehicles which is more onerous than that provided by the Administrator."

Comparison of section 211(c)(4) with the preemption provision respecting vehicle emissions in section $209(\mathrm{a})^{540}$ suggests that the district court better captured the spirit of section 211 (c)(4) than did the court of appeals. Section 209 , by outlawing state standards "relating to the control of emissions from new motor vehicles ... subject to this part," sion regulations are forbidden whether or not the EPA has acted, creating the real possibility of a regulatory void. The fuel provision is sensibly drafted to avoid this risk: the states may act unless the EPA has either regulated or found regulation unnecessary. At the time the district court decided Exxon, the EPA had done neither with respect to the health effects of lead or to volatility. That the EPA had addressed itself to another aspect of the lead problem-protection of control devices-did not satisfy the policy of avoiding a regulatory gap underlying 211 (c)(4).

Unfortunately, the drafting is such as to make full effectuation of that policy impossible. Even before the district court decision, the EPA had "prescribed . . . a control or prohibition applicable to such fuel or fuel additive": it had prescribed a limit on lead in gasoline. Thus the literal terms of the statute required preemption. It was not for the district court to rewrite the statute so as better to

536 Id. at 663.

53738 Fed. Reg. 33,734 (1973); 41 Fed. Reg. 13,984 (1976); id. at 28,352; id. at 42,675.

${ }_{533}$ Exxon Corp. v. City of New York, 548 F.2d 1088, 1092-93 (2d Cir. 1977).

539 Id. at 1095 . The fuel limitations had not been submitted as part of the implementation plan under section 211 (c)(4)(C). Id.

sto 42 U.S.C. \& 7543(a) (Supp. I 1977). See text and notes at notes 408-417 supra.

3412 U.S.C. \& 7543(a) (Supp: I 1977). 
achieve its purpose. No such inescapable language, however, compelled the result reached by the court of appeals with respect to the volatility-of-gasoline regulation. It was true that the EPA had already promulgated standards regulating the content of gasoline, but those standards dealt with only two additives, lead and phosphorus. To treat the lead standards as controlling "fuel" rather than "fuel additive[s]," as the court did, is to resolve an ambiguity in a way that frustrates congressional purpose. Given the ubiquitousness of gasoline, Congress, in its effort to avoid a regulatory gap, could hardly have meant that federal regulation of a single additive in gasoline would preclude state regulation of all others..$^{542}$

The court of appeals's decision that preemption occurs before the effective date of the federal regulation, however, was right. The statute plainly requires only that the federal standard be "prescribed," not that it already be enforceable. A lead time for compliance is often an integral part of a regulatory decision. Once the Administrator has set a date for limitation of a fuel or additive, the congressional policy requiring a federal decision on the need for regulation is satisfied. Just as plainly, the mere proposal of a federal standard is insufficient for preemption; no control has at that stage been "prescribed" as required by the statute, and no federal decision made as demanded by its policy. ${ }^{543}$

Another interesting question concerning the meaning of the preemption provision was raised but not decided in another case in the Southern District of New York. ${ }^{54}$ The city had imposed a tax on leaded fuel; the plaintiff argued the tax was a preempted "control" on the sale of a fuel or additive already regulated by the EPA. The well-known deterrent effect of special taxation and the

${ }^{512}$ Cf. Southern Pac. Transp. Co. v. Usery, 539 F.2d 386 (5th Cir. 1976), cert. denied, 434 U.S. 874 (1977) (holding that regulation of safety aspects of certain railroad operations by another federal agency did not give the railroad industry a blanket exemption from the Occupational Safety and Health Act under a provision making that statute inapplicable to "working conditions . . . with respect to which other Federal agencies . . . exercise statutory authority to prescribe or enforce standards or regulations affecting occupational safety or health," 29 U.S.C. $\$ 653($ b)(1) (1976)); Southern Ry.v. Occupational Safety \& Health Review Comm'n, 539 F.2d 335 (4th Cir.) (same), cert. denied, 429 U.S. 999 (1976).

${ }^{313}$ The reasoning of the Occupational Safety and Health Review Commission in Seaboard Coast Line R.R., 3 O.S.H.C. 1760 (1973), was similar. The Commission concluded that the proposal of a safety regulation by another federal agency did not constitute an "exercise" of "authority to prescribe . . . standards" sufficient to oust OSHA jurisdiction under the provision quoted in note 542 supra. 3 O.S.H.C. at 1760 n.1. See Currie, OSHA, 1976 A.B.F. RESEARCH J. 1107, 1113: "The Commission's view seems right, as otherwise the proposal of a regulation by another agency would create precisely the sort of gap in coverage that it was the evident purpose of the "exercise' requirement to prevent."

su 57th St. Management Corp. v. City of New York, 456 F. Supp. 286 (S.D.N.Y. 1978). 
unlikelihood that Congress meant to deprive states of ordinary sources of revenue suggest that those taxes that bear disproportionately upon leaded fuels, but not those that are nondiscriminatory, should be struck down as preempted "control[s]."

\section{E. Manganese and the Ban on New Fuels and Additives}

The Senate Committee in 1977 was disturbed by reports that an organo-manganese additive called MMT "was impairing the performance of emission control systems and increasing hydrocarbon emissions in test vehicles." 546 The Committee feared that, because of delays produced by the informational and hearing requirements of section $211(\mathrm{c})$, "emission systems currently in use could not be adequately protected" from the dangers of MMT and of potential new additives under the existing control provisions. ${ }^{547}$ The result was a new section 211(f), which not only banned "any gasoline which contains a concentration of manganese in excess of .0625 grams per gallon" 548 but outlawed as well all other new fuels or additives for 1975 and later vehicles as a precautionary measure, unless the fuels were "substantially similar to" those "utilized in the certification" of such vehicles. . $^{548}$

545, Cf. Michelin Tire Corp. v. Wages, 423 U.S. 276 (1976) (construing the Constitution's ban on state "Duties" on "Imports," U.S. CoNST. art. I, § 10). Placement of the preemption provision in subsection (c), which deals only with "control[s]" and "prohibit[ions]," reinforces the inference from the language itself that it does not apply to registration or testing requirements, which are treated separately in subsections (a) and (b) of section 211, 42 U.S.C. $\S 7545$ (a), (b) (Supp. I 1977). Conflicting state requirements as to actual content of fuels under section 211 (c) could certainly be the more burdensome. A strong precedential argument to the contrary is based upon Lubrizol Corp. v. Train, 547 F.2d 310 (6th Cir. 1976), and Lubrizol Corp. v. EPA, 562 F.2d 807 (D.C. Cir. 1977), both holding that a registration requirement was a "control or prohibition under section 211" for purposes of judicial review under section 307 (b), 42 U.S.C. $\$ 7607$ (b) (Supp. I 1977). The court's reliance on section 307's reference to "all of section [211]" and on the disruptive impact of bifurcated review, see 562 F.2d at 813-14, arguably provides bases for distinguishing preemption.

sas S. REP. No. 127, 95th Cong., 1st Sess. 50 (1977).

517 Id. at 90 .

sts 42 U.S.C. \& 7545(f)(2) (Supp. I 1977). Unlike the administrative standards for lead and phosphorus, the manganese limit is not restricted to gasoline for vehicles with sensitive control equipment. It thus imposes burdens upon users of leaded fuel that can be warranted only if deemed necessary to avoid the temptation to put manganese in the wrong car. Such a philosophy was rejected in the case of lead, and the Senate Committee, which had not proposed to limit manganese specifically, said its purpose was to keep harmful additives away from catalysts, "but not to limit the use of such additives in the leaded grades of gasoline." S. REP. No. 127, 95th Cong., 1st Sess. 90 (1977).

54 42 U.S.C. § 7545(f)(1) (Supp. I 1977). Also covered was the "increase" in "concentration" of existing additives. Fuels and additives already introduced since the testing of 1975 vehicles were similarly banned after a grace period of just over one year. Id. $\S$ 7545(f)(3). 
These provisions are not as draconian as they seem, since section 211(f)(4) allows the Administrator to "waive" either the manganese ban or the general one "upon application of any manufacturer" who "establishe[s] that such fuel or fuel additive or a specified concentration thereof . . . will not cause or contribute to a failure of any emission control device or system . . . to achieve compliance" with applicable standards..$^{550}$ Nevertheless, they impose a significant delaying obstacle to technological innovation; they effectively create a permit system that reverses the burden of proof in order to protect the important vehicle-emission program. There is no requirement that the manufacturer show that the new additives will not endanger public health directly.

The Agency has denied applications for waiver with regard to MMT, finding insufficient proof that its use would not impair required control devices.551 In setting those applications for public hearings the EPA had announced that there were "no adversary parties as such"; that its decision "will be applicable to all manufacturers"; that there would be no cross-examination; ${ }^{552}$ and that it would not necessarily base its decision on the record. ${ }^{.53}$ In short, it seems to have conducted a general rulemaking proceeding where the statutory terms "waive," "application," and "establish" appear to have contemplated an individual variance proceeding. ${ }^{554}$ Fortunately, since the pertinent issue is whether an additive will damage control equipment-a general "legislative" one-due process probably does not require a trial-type hearing. ${ }^{.55}$

The EPA also received applications to waive the ban on new fuels for mixtures of gasoline and alcohol ("gasohol"), which hold promise of reducing dependence on foreign petroleum supplies. In order not to interfere with the immediate use of such fuels, the

sso Id. $\S 7545(f)$ (4). If the Administrator fails to act on an application within 180 days, the waiver "shall be treated as granted." Id. Finally, "no action . . . under this section may be stayed by any court pending judicial review." Id. § 7545(f)(5). The reference to "this section" seems a clerical error; the Conference Committee said no stay should be granted in judicial review of "such action," meaning action under the waiver provision to which the stay ban is attached. H.R. REP. No. 564, 95th Cong., 1st Sess. 161 (1977), reprinted in [1977] U.S. Code Cong. \& AD. News 1502, 1542.

sst 43 Fed. Reg. 41,424 (1978).

ss $I d$. at 24,742 .

sss Id. at 24,743 .

sst For similar analysis, see the discussion of section $202(\mathrm{~b})(5)$ at text and notes at notes 189-205 supra.

sss See text at notes 208-218 supra. Moreover, the statute arguably does not create an entitlement to a waiver on proof of the prescribed fact, since it uses the commonly discretionary word "may." 
Agency suspended enforcement of section 211(f) against them, pending decision on the waiver applications. ${ }^{556}$ Such authority seems a highly desirable analog of the judicial power of interlocutory relief, but it appears irreconcilable with the requirement of section 211(f)(4) that a waiver be granted only after "the applicant has established" that the new fuel is harmless to control devices. ${ }^{557} \mathrm{Al}-$ though the Administrator may have some discretion not to enforce the statute despite the apparently mandatory words of section 211(d), a "suspension" seems to go beyond discretion by precluding private enforcement under section $304^{558}$ as well. I see no authority for doing so.

After the prescribed hearing, the gasohol waiver was extended indefinitely, ${ }^{559}$ but a subsequent EPA interpretation of section 211(f) appears to have circumvented the waiver procedure for gasohol and comparable new fuels in the future. The ban on new fuels does not apply to fuels that are "substantially similar" to those used in certification testing, and the Agency has issued an interpretive ruling defining as "substantially similar" to test fuels, among other things, any fuel containing nothing more than carbon, hydrogen, and oxygen. ${ }^{580}$ Gasohol thus no longer requires a waiver, since the ethanol with which it is made meets that definition. ${ }^{561}$ Unquestionably, ethanol is substantially dissimilar to gasoline in many of its physical and chemical properties, but the EPA thought it "similar" in the respect most central to the statutory purpose: it does not impair the performance of emission controls. Yet the existence of the statutory waiver provision casts considerable doubt on the propriety of this interpretation; Congress expressly contemplated that the determination whether a new fuel would impair controls would be made after hearing, and that in the meantime the new fuel would not be marketed. While the EPA purported to limit its ruling to fuels of specified composition, its reasoning is equally applicable to any new fuel. The interpretation invites the manufacturer to make his own decision whether a new fuel will impair controls and to market it without the presale clearance required by the statute..$^{562}$

sss 43 Fed. Reg. 44,565 (1978).

${ }_{557}$ Cf. Lloyd A. Fry Roofing Co. v. EPA, 1 Ill. Pollution Control Bd. Op. 585 (1971) (Board lacked power to issue a temporary restraining order before the resolution of enforcement proceeding).

${ }^{558} 42$ U.S.C. $\$ 7604$ (Supp. I 1977).

559 See 9 ENVIR. REP. (BNA) 1513 (1978).

56044 Fed. Reg. 16,033 (1979).

${ }^{381} \mathrm{C}_{2} \mathrm{H}_{5} \mathrm{OH}$.

${ }^{562}$ Cf. United States v. Chrysler Corp., 591 F.2d 958 (D.C. Cir. 1979) (manufacturer's 
F. Enforcement

Civil penalties of $\$ 10,000$ per day, which the Administrator may without statutory guidance "remit or mitigate," may be recovered by the United States in federal district court under section 211(d) for any violation of the fuel or additive requirements of section $211 .{ }^{583}$ Oddly, nothing is said of EPA actions to enjoin violations of any of the requirements of section 211 , which are not included either in the general injunctive authority of section $113^{564}$ or in that pertaining to vehicle requirements in section 204. .65 "A control or prohibition respecting a motor vehicle fuel or fuel additive," ${ }_{566}$ however, is expressly declared to be an "emission standard or limitation"567 that "any person" may sue to enforce under section 304; this, combined with precedent permitting the inference of injunctive remedies when necessary to effectuate the statutory purpose, ${ }^{568}$ should suffice to permit the United States to seek an injunction as well.

On its face, section 304, which permits suits to enforce a "control or prohibition," would seem to exclude actions to enforce the registration and information requirements of section 211 (a) and (b). Nonetheless, the decisions of two courts of appeals giving a broader construction to a nearly identical provision respecting judicial review, ${ }^{569}$ and especially the ruling by one of those courts that section 211(a) and its implementing regulations "act as a 'prohibition' on the sale of unregistered products," 570 give promise of a contrary interpretation, especially since no reason appears why Congress might have wanted to exclude citizen enforcement of registration or testing requirements.

own testing of vehicles not equivalent of statutory certification process). See text at notes 304-306 supra.

sss 42 U.S.C. $\S 7545$ (d) (Supp. I 1977). The references in the section to violations of "subsection (a) or (f)," "the regulations prescribed under subsection (c)," and "any information required ... under subsection (b)" seem to be all-inclusive.

sw Id. § 7413.

sts Id. $\$ 7523$.

scs Id. \& 7604(f)(2).

set Id. \& 7604(a)(1)(A).

sss E.g., United States v. Republic Steel Corp., 362 U.S. 482, 491-92 (1960) (Rivers and Harbors Act, $\S 10,33$ U.S.C. $\S 403$ (1976)).

sul Lubrizol Corp. v. EPA, 562 F.2d 807 (D.C. Cir. 1977) (construing what is now 42 U.S.C. $\$ 7607(b)(1)$ (Supp. I 1977)); Lubrizol Corp. v. Train, 547 F.2d 310 (6th Cir. 1976) (same).

${ }^{\text {570 }}$ Lubrizol Corp. v. EPA, 562 F.2d at 814. 


\section{AIRCRAFT EMISSIONS}

Section 231 (a), enacted in $1970,{ }^{571}$ now provides that the Administrator, after "public hearings," 572 "shall, from time to time" adopt "emission standards applicable to the emission of any air pollutant from any class or classes of aircraft engines which in his judgment causes, or contributes to, air pollution which may reasonably be anticipated to endanger public health or welfare." ${ }^{573}$ The criteria for setting such standards are implicit in the congressional blueprint for an introductory study of "the extent to which such emissions affect air quality" 574 and "the technological feasibility of controlling such emissions." ${ }_{575}$ They are made explicit in part by the command that such regulations take effect, like vehicle-emission standards under section 202(a), ,576 "after such period ás the Administrator finds necessary . . . to permit the development and application of the requisite technology, giving appropriate consideration to the cost of compliance within such period."'577 This formulation permits regulations that go beyond existing technology.

Except for the hearing requirement, which was made redundant by the 1977 adoption of section 307(d)'s additional procedures applicable to both vehicles and aircraft, ${ }^{578}$ these aircraft provisions closely track the general motor-vehicle provision of section 202(a). But there are differences. The most important is that, in contrast to the vehicle provisions, section 231 is not limited to new aircraft. Nevertheless, the statute authorizes only "emission standards." 573 And just as the Supreme Court has held that the term "emission standards," as used in section $112,{ }^{580}$ does not comprehend the pre-

571 Clean Air Act Amendments of 1970, Pub. L. No. 91-604, § 11(a), 84 Stat. 1703 (amending Clean Air Act § 231(a)) (current version at 42 U.S.C. § 7571(a) (Supp. I 1977)).

572 These hearings should be "legislative." See text and notes at notes 173-186 supra. Since 1977, aircraft-emission standards are subject to the additional procedures of section 307(d), 42 U.S.C. $\$ 7607$ (d) (Supp. I 1977).

s73 42 U.S.C. § 7571(a)(2)-(3) (Supp. I 1977). The 1970 language was similar, except that it required promulgation of standards within a year. Clean Air Amendments of 1970, Pub. L. No. 91-604, § 11(a)(1), 84 Stat. 1703 (amending Clean Air Act $\S 231$ (a)). The present language, identical to that applicable to fuel regulation under section 211 (c)(1), 42 U.S.C. $\S 7545$ (c)(1) (Supp. I 1977), was designed to reflect the cautionary approach established in the Ethyl case, discussed in text and notes $485-525$ supra.

${ }^{374} 42$ U.S.C. $\S 7571$ (a)(1)(A) (Supp. I 1977).

${ }^{573}$ Id. $\& 7571(\mathrm{a})(1)(\mathrm{B})$.

${ }^{578}$ See text at notes 84-88 supra.

57742 U.S.C. $\$ 7571$ (b) (Supp. I 1977).

${ }^{573}$ Clean Air Act Amendments of 1977, Pub. L. No. 95-95, § 305(a), 91 Stat. 772 (amending Clean Air Act $\$ 307(d)$ ) (current version at 42 U.S.C. $\$ 7607$ (d) (Supp. I 1977)).

57942 U.S.C. \& 7571(a)(2) (Supp. I 1977).

${ }^{s s 0} \mathrm{Id} . \S 7412(\mathrm{c})(1)(\mathrm{A})$. 
scription of work practices designed to avoid asbestos emissions during building demolition, ${ }^{581}$ so regulation of aircraft use aimed at reducing emissions may not constitute "emission standards" under section 231. I consider such distinctions artificial, and I think the authority to regulate aircraft use should be conferred explicitly.

A different aspect of federal aircraft regulation prompted another provision foreign to the vehicle sections. The 1970 Act required that before promulgating regulations applicable to aircraft, the Administrator consult "with the Secretary of Transportation in order to assure appropriate consideration for aircraft safety"; 582 the 1977 amendments substitute a discretionary presidential veto of both existing and future standards after opportunity for another "public hearing," if the Secretary of Transportation finds "that any such regulation would create a hazard to aircraft safety." 583 The House Committee, which would have vested the veto authority in the Secretary himself, explained that the pre-existing consultation requirement was not considered "an adequate mechanism" to effectuate "the paramount concern of aircraft safety." 584 The Agency itself has promised that its regulations "will be revised if at any time the Secretary . . . determines that an emission standard cannot be met . . . without creating a safety hazard." 585

A complex set of emission regulations with differential application to new and to existing aircraft engines was adopted in 1973. ${ }^{586}$ The EPA found that aircraft were "significant sources of emissions of carbon monoxide, hydrocarbons, and nitrogen oxides in some . . . regions in which the . . . air quality standards are being violated, as well as being significant sources of smoke." 587 The emission standards, however, were "not quantitatively derived from . . . air qual-

sss Adamo Wrecking Co. v. United States, 434 U.S. 275 (1978).

582 Clean Air Amendments of 1970, Pub. L. No. 91-604, § 11(a)(1), 84 Stat. 1704 (amending Clean Air Act $\S 231(\mathrm{c})$ ) (current version at 42 U.S.C. $\$ 7571(\mathrm{c})$ (Supp. I 1977)).

s33 Clean Air Act Amendments of 1977, Pub. L. No. 95-95, \& 225, 91 Stat. 769 (amending Clean Air Act $\$ 231(c)$ ) (current version at 42 U.S.C. $\$$ 7571(c) (Supp. I 1977)).

ss H.R. REP. No. 294, 95th Cong., 1st Sess. 277 (1977), reprinted in [1977] U.S. CodE Cong. \& AD. News 1077, 1356.

ses 40 C.F.R. $\$ 87.6$ (1978).

sst 38 Fed. Reg. 19,088 (1973) (current version at 40 C.F.R. $\$ 87$ (1978)). The regulations "shall apply" to "aircraft of foreign registry . . . in a manner consistent with any obligation assumed by the United States in any treaty, convention or agreement." 40 C.F.R. $\$ 87.3$ (c) (1978). I take this to mean foreign planes are covered unless exempted by such an agreement, though it is not clear to me whether this is an ideal means of reconciling competing American and foreign interests. The proposed revised regulations would apply to foreign carriers, in order to minimize emissions and be fair to domestic competitors, until standards at least as stringent are adopted by an international organization. See 43 Fed. Reg. 12,621 (1978).

s87 38 Fed. Reg. 19,089 (1973). 
ity considerations . . . but, instead, reflect EPA's judgment as to what reduced emission levels are or will be practicable to achieve." ${ }^{588}$ It was expected that the achievement of the standards would "contribute to the maintenance of the quality of the air in and around major air terminals throughout the post-1975 era," and would cost $\$ 141,000,000$ over a ten-year period, representing for new engines a cost increase of no more than $3 \% .{ }^{500}$ A major revision of the regulations is pending, ${ }^{591}$ and the date for compliance has meanwhile been extended. ${ }^{582}$

One interesting feature of the regulations is the provision for a temporary exemption from certain requirements upon a showing of good-faith inability to comply ${ }^{593}$ and a plan for achieving compliance "in the shortest time which is feasible." no mention of variances, but the statutory criteria are general enough to permit them as reasonable accommodations of costs and benefits in individual cases. Indeed, they constitute a case-by-case application of the statutory direction to make standards applicable "after such period as . . . necessary to permit . . . application of the requisite technology." 595 Further, since that determination is to be made "giving appropriate consideration to the cost of compliance," the term "feasible" in the regulations should be construed to mean "practicable." "596

Section 232(a) directs the Secretary of Transportation to adopt regulations that will enforce the aircraft emission standards developed by the Administrator. 597 Those regulations "shall include provisions making such standards applicable in the issuance, amendment, modification, suspension, or revocation of any certificate au-

588 Id.

${ }^{589} I d$.

${ }^{590}$ Id. at 19,090 .

591 43 Fed. Reg. 12,615 (1978).

${ }^{592}$ Id. at 12,614 .

${ }^{593} 40$ C.F.R. $\$ 87.101(a)(1978)$.

s94 Id. $\$ 87.101(\mathrm{a})(3)$.

${ }^{505} \S 231,42$ U.S.C. $\S 7571$ (b) (Supp. I 1977). These provisions may distinguish section 231 from the new-source performance standard provision in section 306 of the Federal Water Pollution Control Act, 33 U.S.C. $§ 1316$ (1976), whose sole temporal reference is the flat requirement that all sources comply "after the effective date," and which was held in the light of rather persuasive legislative history not to require or permit the EPA to allow variances. E.I. du Pont de Nemours \& Co. v. Train, 430 U.S. 112 (1977).

598 Cf. Industrial Union Dep't v. Hodgson, 499 F.2d 467, 477 (D.C. Cir. 1974) (word "feasible" in section 6(b)(5) of the Occupational Safety and Health Act of 1970, now codified at 42 U.S.C. $\$ 655(b)(5)$ (1976), includes "economic feasibility"); Currie, OSHA, supra note 543 , at 1136.38 (same).

${ }^{527} 42$ U.S.C. § 7572(a) (Supp. I 1977). 
thorized by the Federal Aviation Act or the Department of Transportation Act." 598 Nothing is said of actions for penalties or for injunctions. The effect is to extend the existing permit system, through which the Department of Transportation regulates aircraft use, to cover emission standards, avoiding duplication at the expense of dividing responsibility for pollution control between the EPA and the Department of Transportation.

What the Secretary may do to punish noncompliance, short of refusing or revoking the certificate, is not clear. I would not read the statute's general language as taking the highly unusual step of authorizing administrative creation of a schedule of money penalties, though such penalties are an important tool in the enforcement of the standards. On the other hand, a government power to sue for an injunction can probably be inferred despite the statutory specification of enforcement through the permit process of the Department of Transportation. ${ }^{598}$ Moreover, since a duty to comply with the standards seems implicit in the provision for their adoption, ${ }^{600}$ it appears that "any person" sion standard ... under this chapter" pursuant to section $304 . .^{602}$

Section 233 contains a preemption provision that differs from those applicable either to vehicle emissions ${ }^{603}$ or to fuels, ${ }^{604}$ forbidding state and local standards "respecting emissions of any air pollutant from any aircraft or engine thereof" unless "identical" to the federal standards. ${ }^{605}$ In contrast to the fuel section, preemption is not expressly made dependent upon prior federal adoption or rejection of a standard; the language invites the unpalatable conclusion that state action is precluded if the EPA does nothing at all. ${ }^{606}$

In contrast to the automotive provision, there is no explicit reservation of state authority to regulate aircraft "use, operation, or movement." That the need for uniform regulation is greatest with respect to construction of the aircraft itself might conceivably jus-

588 $I d$.

ss: See text and notes at notes 564-568 supra.

600 In contrast, the vehicle-emission standards apply basically through the prohibition on sale of uncertified vehicles rather than through direct prohibitions on the user. See text and notes at notes 298-300 supra.

60142 U.S.C. $\$ 7604(\mathrm{a})(1)$ (Supp. I 1977).

$\omega 2$ Id. $\S 7604$ (f)(1).

wes text and notes at notes 408-417 supra.

See text and notes at notes 531-545 supra.

cos 42 U.S.C. $\$ 7573$ (Supp. I 1977).

cos See Jorling, supra note 36 , at 1131 (also noting that the preemption provision "was generated by a California law which was to regulate emission controls on aircraft effective 1 January 1971"). 
tify construing the preempted "standard[s] respecting emissions" not to include use regulations. More significant, perhaps, is that what the state may not do is expressed in substantially the same words that define the federal authority to adopt regulations: the EPA may, and the states may not, regulate "emission[s]." Thus the states seem to be preempted from adopting use regulations if and only if the EPA has authority to adopt them. The reservation of state authority to regulate vehicle use was redundant on either theory, and its omission from the aircraft provision is therefore immaterial; for Congress to oust state regulation from an area it has not authorized the federal agency to enter would be unconscionable and ought not to be inferred.

The question may still be important, as the reodification of ground operations, such as taxiing and idling, would probably lead to a substantial reduction in airport emissions of hydrocarbons and carbon monoxide. Under present law, I think the states may regulate such operations because precedent suggests the EPA may not. ${ }^{607}$ I think Congress should give the EPA authority to do so. At the same time though, Congress should modify the preemption section to make explicit that state use regulations not requiring alteration of aircraft equipment are permissible, at the very least when necessary to achieve an acceptable level of air quality, as is provided with respect to fuel standards by section 211.608

\section{The Mobile-Source Provisions: An Appraisal}

\section{A. Technology Forcing}

1. Reasons for Optimism. The central motivating idea of the mobile-source program, at least since 1970, has been the daring principle that invention can be stimulated by setting future requirements that cannot be met by existing technology. If the threat has worked at all, there is reason for some surprise. One commentator has invoked the analogy of the tale of Rumpelstiltskin, in which an evil king locked a maiden in a room full of straw with orders to spin

con See text at notes 579-581 supra; Jorling, supra note 36, at 1124-25 (agreeing with that conclusion).

${ }^{c 03}$ See text and note at note 533 supra. The one reported decision to date on aircraft standards struck down a prohibition on the discharge of jet fuel after engine shutdown because it arbitrarily ignored the danger of engine damage and injury to persons by fire. Citronelle-Mobile Gathering, Inc. v. McLucas, 432 F. Supp. 821 (S.D. Ala. 1977). The problem of fuel discharge warrants further study; one report has estimated that "110 tons of castoff jet fuel were dumped into the air surrounding Washington's National Airport in 1970," and according to the court the catch tanks installed to ameliorate the problem still discharged the fuel into the atmosphere. Id. at $825 \&$ n.6. 
it into gold by morning. ${ }^{809}$ Another has observed that "there is a certain comfort in being asked for the impossible: you know you will not actually have to do it." 110 A third argues that a "retreat" from strict standards "is apparently inevitable" when policymakers "are confronted with specific instances of economic and social disruption." 111 One article cites the vehicle program as living proof of the inherent futility of "aspirational commands." 612

Indeed, there has been slippage in attaining the noble goals of the 1970 statute. The unrealistically brief definition of an automobile's "useful life" may have damaged the program before it even began. The industry's tardiness in meeting the standards has resulted not only in several postponements of the compliance dates themselves but also in an EPA policy that allows massive numbers of vehicles to be sold that do not meet even the watered-down interim standards. Solicitude for the manufacturer's need for assurance that he may market his product and the need to develop quick testing procedures have exacerbated the difficulty of reducing the gap between prototype testing and compliance of production vehicles in actual use. Further, as Professor Rodgers has pointed out, conventional recall campaigns that depend upon voluntary action by the owner "have not been wholly successful" even when the owner stands to benefit directly by the repair; and the absence of widespread inspection requirements makes the owner "a lukewarm candidate for citizen enforcer" of the warranties. ${ }^{613}$ Moreover, both the warranty and recall provisions necessarily exempt performance failures attributable to improper maintenance, and even the prohibition of deliberate tampering is inapplicable to the owner himself. Despite all the postponements of the substantive compliance standards, the General Accounting Office estimated in early 1979 that a whopping $80 \%$ of vehicles in use failed to meet even the applicable revised standards. ${ }^{614}$ Finally, as Howard Margolis has noted, the much-touted "technology-forcing" standards required the industry to do nothing more than it acknowledged in 1970 it could do within the next ten years. ${ }^{615}$ (1974).

${ }^{609}$ Batchelder, Land Use Transportation Controls for Air Quality, 6 URB. LAw. 235, 235

10 Margolis, supra note 339, at 13.

"II La Pierre, Technology-Forcing and Federal Environmental Protection Statutes, 62 IowA L. Rev. 771, 837 (1977).

$\$ 12$ Henderson \& Pearson, Implementing Federal Environmental Policies: The Limits of Aspirational Commands, 78 CoLuM. L. Rev. 1429 (1978).

"13 W. RODGERS, supra note $36, \S 3.15$, at $301-10$.

" See 9 ENVIR. REP. (BNA) 1827 (1979).

"1s Margolis, supra note 339, at 6, 14-15. 
The lesson to be drawn from Rumpelstiltskin, however, is the opposite of that implied by our pessimistic observer. For the maiden received unexpected help, and in the morning the room was full of gold. Similarly, though for reasons no doubt more prosaic, we have come a long way in reducing motor-vehicle emissions since the federal program began in 1965. By 1970, as Margolis acknowledges, emissions of hydrocarbons and carbon monoxide had already been reduced, at least from prototypes, by $60 \%{ }^{616} \mathrm{By} 1977$ the remaining $\mathrm{HC}$ and $\mathrm{CO}$ prototype emissions had been trimmed by over $50 \%$, and there seems to be general expectation that only minor kinks remain to be ironed out in time to reduce them by a full $90 \%$ from the 1970 levels. This seems to be no mean accomplishment, and it does not seem probable that industry would have come so far without the pressure of the law. Perhaps, despite "the absence of any real threat" that the deadlines would be strictly enforced, ${ }^{617}$ the cosmetic efforts industry felt compelled to make in order to establish its good faith could not, given the resourcefulness of its engineers, but have produced some improvement. ${ }^{618}$

Indeed, although I have argued that Congress's insistence on prescribing technical minutiae risks unnecessary error in the handling of complex technical matters and necessitates repeated and inefficient congressional tinkering, ${ }^{619}$ the incentive effect of the technology-forcing requirements may well have been significantly enhanced by the need to persuade Congress itself, rather than a mere agency, that the industry had done all it could.

Moreover, this improvement has been achieved despite a serious and entirely unnecessary deficiency in the statutory incentive scheme. Postponements have repeatedly been granted, and an enormous discrepancy between prototype and production tolerated, on the explicit basis that to enforce the standards would be unreasonably burdensome. No doubt an industry shutdown would have been unreasonable, but that does not mean the best expedient was to give the manufacturers a free pass. Implicit in these decisions is the

sis Id. at 5.

617 La Pierre, supra note 611 , at 796.

(18 The House Report gave evidence that strict statutory standards had actually stimulated research, citing an EPA conclusion that "developmental efforts to meet the $0.4 \mathrm{NO}_{x}$ standard have slowed to a near stop, because of the possibility that Congress may act to relax or abolish the $\mathrm{NO}_{\mathrm{X}}$ standard." H.R. REP. No. 294, 95th Cong., Ist Sess. 240 (1977), reprinted in [1977] U.S. Code CONG. \& AD. NEws 1077, 1319.

619 For a similar conclusion as to the Clean Air Act generally, even before the 1977 revisions, see Stewart, The Development of Administrative and Quasi-Constitutional Law in Judicial Review of Environmental Decisionmaking: Lessons from the Clean Air Act, 62 Iowa L. REv. 713, 764-65 (1977). 
assumption that shutdown is the expected sanction for sale of uncertified vehicles, and this otherwise less than obvious assumption was reinforced by Congress's 1977 decision to provide for certification of inadequate heavy-duty vehicles upon payment of nonconformance penalties-an antidote to what the Committee viewed as the rule that uncertified vehicles might not be sold.

Nonconformance penalties should be extended to all vehicles, and they should apply when it is the whole industry, not just a "laggard" or two, that is unable to meet the standards. So extended, penalties could help considerably against both prototype and production-line failures, and they should make it possible to provide a rational system of administrative relief procedures without jeopardizing the statutory incentive.

The gap between production and performance in actual use, however, is another story. Conceivably, technology might be pushed to deal with this problem by requiring, subject to appropriate penalties, the development of technology less prone to deterioration in use, such as engines with more complete combustion. Yet Congress has shown no signs of an intention to force technology in that direction.

2. Reasons for Pessimism. Despite substantial progress, however, the most striking aspect of the 1977 mobile-source amendments is not the relatively unimportant extension of the deadlines for $90 \%$ reductions, but Congress's decision not to press harder for the development of still better technology in the face of strong evidence that what section 202 (b) requires will not do the job. The nitrogen oxide picture, as painted by the House Committee, ${ }^{620}$ is far from promising. Even more disturbing, perhaps, is the oxidant situation. In February 1978 the EPA reported that 103 of the 105 urban areas with over 200,000 population "consistently experience photochemical oxidant levels above the NAAQS [National Ambient Air Quality Standards]." ${ }_{621}$ In 1977 it had told the House Committee that from 15 to 48 regions would continue in violation beyond the year 2000 even if the statutory hydrocarbon-emission standards were met. ${ }^{622}$ In relaxing the oxidant standard on the basis of new health information in February 1979, the EPA observed that "[e]ven with aggressive control programs . . . it will be very diffi-

120 See text and notes at notes 56-58 supra.

121 43 Fed. Reg. 8962-63 (1978).

122 H.R. REP. No. 294, 95th Cong., 1st Sess. 255 (1977) (quoting an EPA report entitled "Air Quality and Health Effects of Alternate Exhaust Emission Standards for Light Duty Vehicles" (Mar. 21, 1977 draft)), reprinted in [1977] U.S. Code Cong. \& AD. NEws 1077, 1334. 
cult for some urban areas to achieve the standard within the next 10 years"223 - the outside date set by the 1977 amendments. These predictions appear to support the Agency's recommendation, quoted by the Committee, that " "all hydrocarbon controls reasonably possible are needed for light duty vehicles." "624

While the House Report quite properly noted that its 1977 amendments balance a variety of legitimate concerns, "including protection of public health, economic and technical feasibility," 625 a proper concern for cost and feasibility is not incompatible, as the House Report implies, with the technology-forcing philosophy of section 202(b). That section contemplated relief for manufacturers, though largely through the cumbersome amendment process, if good-faith efforts were unavailing. It is true that section 202(a) appears to provide authority for the EPA to continue to force technology beyond the section 202 (b) requirements in order to protect health and welfare. The enactment of section 202(b), however, shows that Congress in 1970 was unwilling to leave it to the Agency to determine how far technology should be forced. It is surprising that it left that decision to the Agency in 1977 in the face of strong evidence that section 202(b) alone would not do the job.

In short, given the bleak predictions as to the adequacy of the present statutory requirements, the decision not to tighten them and actually to relax the ultimate $\mathrm{NO}_{\mathrm{x}}$ standard seems to represent a significant departure from the principle of forcing technology. The key to satisfactory air quality in the absence of additional amendments thus appears to lie largely outside the mobile-source provisions, and that brings me to my next set of concluding observations about this part of the statute.

\section{B. The Interstitial Nature of the Mobile-Source Provisions}

The mobile-source provisions of Title II of the Clean Air Act are representative in one respect of the entire federal program. Unlike most state laws, they do not provide a comprehensive framework for complete regulation of their subject. Instead they are the aggregate of a cautious series of piecemeal, incremental steps designed to limit direct federal regulation to those aspects of the problem most in need of and most amenable to federal solution.

Thus the initial step, and even today the central theme of Title

623 44 Fed. Reg. 8202, 8219 (1979).

e24 H.R. REP. No. 294, 95th Cong., 1st Sess. 255 (1977), reprinted in [1977] U.S. CodE Cong. \& AD. News, 1077, 1334.

${ }^{225}$ Id. at 234, reprinted in [1977] U.S. Cone Cong. \& AD. News at 1334. 
II, was federal regulation of emissions from new vehicles, with federal enforcement principally brought to bear on the manufacturer. The 1970 amendments added authority over aircraft emissions and fuel composition, both also areas in which there was great potential for progress through uniform regulation of a relatively small number of persons.

The absence of a general authorization to adopt regulations to control pollution from mobile sources can create interpretive difficulties. Thus the EPA can require that lead-free gasoline be offered for sale only if the requirement is a "control or prohibit[ion]" on "the sale of any fuel or fuel additive" under section 211 , and it can limit idling time only if the limitation is a "standard applicable to the emission of any air pollutant from . . . aircraft engines" under section 231(a). It also has meant that the dilatory process of new legislation must be invoked to deal with newly perceived problems. Fuel composition, for example, could not be regulated under the original authority to adopt standards for "emission[s]" from "new motor vehicles," and a special provision had to be added in 1977 to assure that the EPA could prescribe specifications for fill pipes in order to reduce evaporative emissions during fueling of vehicles. ${ }^{626}$

There still are conspicuous gaps in Title II even as to the regulation of new mobile sources, a subject that cries aloud for a high degree of uniformity. While section 202(a) allows regulation of emissions from all "new motor vehicles," section 216(2) defines "motor vehicle" as "any self-propelled vehicle designed for transporting persons or property on a street or highway." ${ }^{27}$ Excluded are trains, ships, and agricultural or construction equipment, though obviously their emissions can be significant. ${ }^{628}$

Congress has been cognizant that Title II in itself will not suffice to solve pollution problems generated by mobile sources. In part

22 Clean Air Act Amendments of 1977, Pub. L. No. 95-95, $\S 215,91$ Stat. 760 (amending Clean Air Act $\S 202(a)(5)$ ) (current version at 42 U.S.C. $\S 7521(\mathrm{a})(5)$ (Supp. I 1977)).

s27 42 U.S.C. \& 7550(2) (Supp. I 1977).

c23 In 1970 the Senate Committee proposed to extend section 202 to aircraft, vessels, locomotives, and agricultural equipment, as well as to existing commercial vehicles, arguing that "[s]tandards for vessels and locomotives are appropriate because of [sic] their use characteristically involves interstate travel, with large numbers of them congregating in ports and yards in or near areas of high population and air pollution concentration." S. REP. No. 1196, 91st Cong., 2d Sess. 24 (1970). Except with respect to aircraft, this proposal remains unimplemented. The 1977 amendments require a study of railroad emissions. Clean Air Act Amendments of 1977, Pub. L. No. 95-95, $\$ 404,91$ Stat. 793, reprinted in 42 U.S.C. $\S 7401$ at 1258 (Supp. I 1977). See H.R. Rep. No. 564, 95th Cong., 1st Sess. 186-87 (1977), reprinted in [1977] U.S. Code Cong. \& Ad. News 1502, 1566-68; S. REP. No. 127, 95th Cong., 1st Sess. 93 (1977). 
its answer has been to leave the residual task to the states, for section 116 emphasizes that, with specified exceptions, "nothing in this chapter shall preclude or deny the right of any State or political subdivision thereof to adopt or enforce . . . any requirement respecting control or abatement of air pollution." ${ }^{29}$ Even such a subject as what equipment is required on new locomotives or vessels has been left to the states, though federal regulation would be manifestly preferable. ${ }^{630}$

Another striking feature of the mobile-source provisions, however, is their tendency to oust the states from regulation of specific areas as they are subjected to federal scrutiny. First employed as to new-vehicle emissions in 1965, preemption was extended to fuel regulation and to aircraft in 1970 . Opposed as I am to depriving the states of authority to protect their people, I nevertheless think mobile sources are one category in which the arguments for preemption are at their strongest, especially when regulation is to be directed at the manufacturer.

State measures respecting the use of vehicles, in any event, are not preempted, and Congress in other sections of the Act has attempted to ensure that measures in addition to those authorized by Title II are taken to limit mobile-source emissions where such action is necessary to achieve satisfactory air quality. State plans for im-

62942 U.S.C. $\$ 7416$ (Supp. I 1977).

sso That such state regulation is not generally forbidden by the commerce clause was established by the Supreme Court in Huron Portland Cement Co. v. City of Detroit, 362 U.S. 440 (1960). The Court upheld application of a municipal smoke ordinance to a vessel in interstate trade although compliance would require "structural alterations":

State regulation, based on the police power, which does not discriminate against interstate commerce or operate to disrupt its required uniformity, may constitutionally stand.

... [T] he local ordinance . . . is a regulation of general application, designed to better the health and welfare of the community. And while the appellant argues that other local governments might impose differing requirements . . . , the record contains nothing to suggest the existence of any such competing or conflicting local regulations.

Id. at 448. Moreover, the Court held, the smoke ordinance did not invalidly impinge upon the authority granted by a federal license to operate in navigable waters: while "[a] state may not exclude from its waters a ship operating under a federal license," "[t]he mere possession of a federal license . . . does not immunize a ship from the operation of the normal incidents of local police power." Id. at 447.

A limit may be found in People v. Atchison, T. \& S.F. Ry., 268 Cal. App. 2d 501, 74 Cal. Rptr. 222 (1968), invalidating a state prohibition on smoke emissions from diesel locomotives as a burden on commerce: "there is no known way to prevent discharge of black smoke when the engine starts from a standstill." Id. at 502, 74 Cal. Rptr. at 223.

The Court in Huron further noted that the federal statute itself, in what has since become section 116,42 U.S.C. $\$ 7416$ (Supp. I 1977), expressly provided against statutory preemption. 362 U.S. at 445.46 . 
plementing ambient air-quality standards under section 110 are to contain necessary "transportation control" measures to that end, specifically including the inspection and maintenance programs that appear essential to assuring compliance by vehicles in use..$^{631}$ The EPA may prescribe and enforce most such measures itself in default of state action. ${ }^{632}$

Title II therefore is difficult to evaluate in isolation. Although broader powers of direct regulation might well be desirable, the most serious deficiencies can in theory be remedied by alternative federal action. In the case of nitrogen oxides, as the Senate Report argued, it may be desirable to achieve further progress by pushing technology to control significant sources such as power plants under section 110; but a recent study has concluded that stationary sources actually make only a small contribution to long-term ambient levels. ${ }^{633}$

In any case, hydrocarbons and the oxidants that result from them are essentially an automotive problem, and the alternatives to better control of vehicle hydrocarbon emissions have themselves proved most burdensome and unpalatable, as the House Committee itself suggested when it argued that "[r]apid clean up of automobiles is necessary to avoid placing undue reliance on transportation controls." "634 The prospects for curing automotive pollution, in short, do not appear particularly bright; yet Congress seems largely to have abandoned one of the most promising means toward that end.

\footnotetext{
(s) 42 U.S.C. $\S 7410$ (Supp. I 1977).

(32 Id.

as See 9 EnviR. Rep. (BNA) 2028, 2029 (1979).

is H.R. REP. No. 294, 95th Cong., 1st Sess. 268 (1977), reprinted in [1977] U.S. CoDE
} Cong. \& AD. News 1077, 1347. 